Portland State University

PDXScholar

$12-8-2020$

\title{
New Perspectives on Johannes de Muris and his Notitia artis musicae
}

Jeffrey Allan Arnsdorf

Portland State University

Follow this and additional works at: https://pdxscholar.library.pdx.edu/open_access_etds

Part of the History Commons, and the Music Theory Commons

Let us know how access to this document benefits you.

\section{Recommended Citation}

Arnsdorf, Jeffrey Allan, "New Perspectives on Johannes de Muris and his Notitia artis musicae" (2020). Dissertations and Theses. Paper 5624.

https://doi.org/10.15760/etd.7496

This Thesis is brought to you for free and open access. It has been accepted for inclusion in Dissertations and Theses by an authorized administrator of PDXScholar. Please contact us if we can make this document more accessible: pdxscholar@pdx.edu. 
New Perspectives on Johannes de Muris and his Notitia artis musicae

\author{
by
}

Jeffrey Allan Arnsdorf

A thesis submitted in partial fulfillment of the requirements for the degree of

\author{
Master of Art \\ in \\ History
}

\begin{abstract}
Thesis Committee: John S. Ott, Chair Richard H. Beyler

Thomas M. Luckett

Brad Berman
\end{abstract}

Portland State University 2020 


\begin{abstract}
At the end of the 1310s, Norman mathematician and astronomer Johannes de Muris (c. 1295-after 1344) reconceived the existing musical notation system on a mathematical foundation. His Notitia artis musicae dramatically increased the fidelity with which the system could represent complex rhythmic patterns. In recent years, musicologists, particularly Karen Desmond, have begun to incorporate the scholarship of historians of astronomy in their work on Muris and the Notitia. These studies take as their focus conceptual shifts in music theory and practice. This thesis repositions the perspective to Muris himself, seeking to shed light on his intention in writing the Notitia.

My investigation of Muris's intentions involves two complementary approaches: First, I explore the contexts of his early life — his Norman heritage, curricular and extracurricular experience as a university student in Paris, and exposure to musical innovations. Then I analyze the Notitia, focusing on its generally neglected first book, of which I provide the first English translation. I conclude that Muris wrote the Notitia in order to bolster his reputation as a capable and innovative mathematician by providing a rational explanation for the function of musical time based on observation and both Aristotelian and Ptolemaic principles. I also demonstrate that Muris's modifications of the existing notational system were modeled on the astronomical method for mathematically organizing time. These conclusions enhance our understanding of the ways in which late medieval scholars could apply knowledge across disciplinary boundaries and remind us of the role of individuals' personal motivations in the advancement of arts and sciences. It further provides a holistic framework with which to contextualize existing scholarship while suggesting a fruitful avenue for future research.
\end{abstract}




\section{Dedication}

This thesis is dedicated to the memory of my grandparents Carl and Jean Powers. I know how proud they would have been to see me reach this accomplishment. This one is for you, Gramps and Gramms. 


\section{Acknowledgments}

I have been blessed with the most supportive family and friends a man could ask for. For whatever merit this work may contain, it would not have been possible without their love and encouragement. To my loving parents, Bruce Arnsdorf and Annie Tietze, thank you for your unwavering faith in me. To the rest of you (you know who you are), you make my life worth living.

A special loving thanks must go to Jen Raynak for the countless hours she spent not just listening to me rant about every detail of my journey with Muris, but also engaging with helpful questions and feedback. Beyond that, she acted as an insightful beta reader and indispensable research assistant. If that weren't enough, she produced the map of Lisieux to my exact specifications and the fantastic rendering of Muris's complex diagram (see $\mathrm{p}$. 153). Did I mention that she delivered me dinners during my final mad weeks of writing and editing? I love you, Jen.

I owe an incalculable debt of gratitude to David Cole, Ryder Russell, Karen Ready, and Tom Trotter for their invaluable and extensive help on my translation of the first book of the Notitia artis musicae. It is no exaggeration to say that I would not have been able to do it without their Latin expertise and overwhelming generosity. What's more, it was a delight to be in their company during the course of the project. A special thanks goes to David Cole, who fielded with grace and diligence innumerable emails filled with questions of Latin translation. He has served not only as an inestimable resource but also as a tutor and friend. Thank you, David. 
I would like to thank Dr. John Ott for putting up with me for all these years (he was also my undergraduate adviser). In particular, I am grateful that he never looks backwards (a strange thing to appreciate in a historian, I know). At our early-term meetings, I was consistently behind the goals we had set the last time. Never did he waste time on disappointment or regret. Never did he add to my guilt. I cannot express how much that has helped. I look forward to calling you John.

I would like to extend warm gratitude to Dr. Brad Berman, who introduced me to the seemingly impenetrable world of Aristotle and spent many hours helping me work through the details of Muris's philosophy. Thank you for being such an engaged teacher.

To my advocate, editor, and dear friend Karen Ready, I cannot give enough thanks. Her unending support and encouragement have both kept me going and dramatically improved the quality of my writing. In whom else could I find an expert knowledge of the English language, a warm heart, and a trenchant understanding of life's true priorities? Maybe it's time I memorize some poetry, Karen.

A special thanks goes to Jonathan Ash, who drew me an awesome kardaga just because I asked him to. I wish I got to see you more.

I would like to thank Sammy Black for helping me wrap my head around the mathematics of Muris's description of the semitone for two solid hours. I owe you a beer, Sammy.

To the wonderful History Department office staff, Andrea Janda and Jeff Brown, goes a warm thanks for their friendly aid with all variety of conundra. You guys are the best! 
My pursuit of a master's degree would not have been feasible without the award of a Portland State University History Department teaching assistantship. Thank you for this opportunity! I also received funding from the Gordon B. Dodds Friends of History Endowed Fellowship and the Stephanie K. Oliver Graduate Award, and for that I am most grateful.

It should go without saying that, after all this assistance, the deficiencies that remain in this work are entirely my own. 
Abstract

Chapter Two

The Intellectual Foundations of ars nova Music Theory, a Historiography.................... 14

Chapter Three

Johannes de Muris: The Early Years................................................................ 38

Normandy and Lisieux

Paris

The Dantean anomaly and Great Famine

Parisian student life during rough times

Study at the University of Paris

Musical life in Paris

Observation in Normandy

Chapter Four

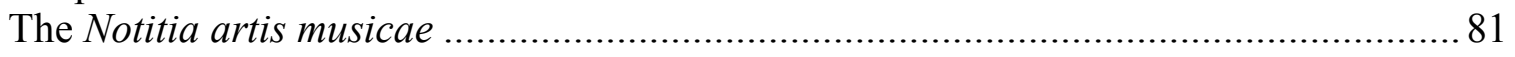

Book I - "Prologus"

Book I - Musica theorica

Book II - Musica practica

Conclusion

Chapter Five

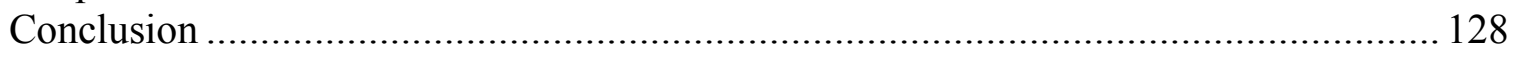

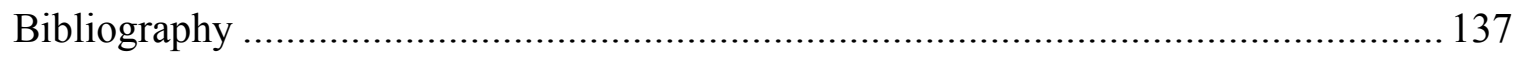

Appendix

Translation of Book I of the Notitia artis musicae ................................................ 150 


\section{List of Tables}

Table 1 Notes described in Franco's Ars cantus mensurabilis .....................................67

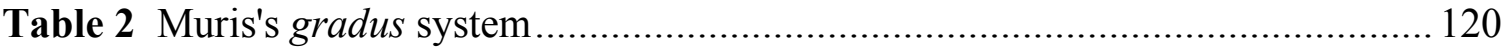




\section{List of Figures}

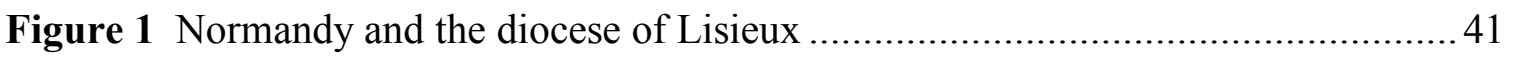

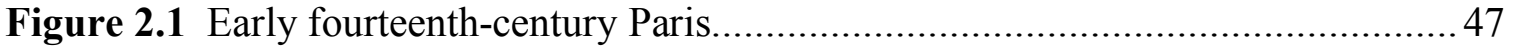

Figure 2.2 Latin Quarter of Paris .................................................................... 52

Figure 3 Artist's interpretation of Muris's kardaga ............................................... 77 


\section{Preface}

When I started down the academic path, my desire was to combine my love of music with my interest in history. I was particularly interested in how music fit into broader historical narratives. What I discovered is that disciplinary boundaries dictate that the history of music reside within the purview of music departments. Music tends to be merely mentioned in or left out of generalist histories. My goal, then, became to do whatever I could to bring music to the history department. So I set to the task of familiarizing myself with the musicological literature. On this journey, the scholarship itself has been my only guide, as my institution employs no medieval musicologist who might help lead the way. Left on my own, I made my way as best I could, bumbling in the dark and on more than a few occasions making "discoveries" that in time were shown to have been covered by some scholar or other whose work I had yet to happen upon. In the course of researching for my undergraduate thesis - which examined the rapid "progress" of literate polyphony c. 1250-1400-I encountered Johannes de Muris, who became a central character in my writing. It was also at this time that I discovered Dorit Tanay's Noting Music, Marking Culture: The Intellectual Context of Rhythmic Notation, 1250-1400 (1999), a complex work that has still not received the critical analysis it deserves. ${ }^{1}$ Tanay's book, though inscrutable to my undergraduate brain, opened the door to the vast and intricate subject of the relationship between medieval music theory and contemporary modes of scholastic thought.

\footnotetext{
${ }^{1}$ Although it gets cited frequently, as far as I know it has never been reviewed. Lamentably, I do not engage with this work to the degree that I would have liked in this thesis.
} 
When I returned to campus in pursuit of a master's degree, it was this subject that recommended itself as a thesis topic. The difficulty lay with finding a niche not covered by Tanay. Alternatively, I could have chosen to challenge some point of hers, a task for which I ultimately deemed myself unqualified. In the years since the completion of my bachelor's degree, my interest in situating music within a broader historical narrative has not changed. Broad historical narratives, however, do not lend themselves well to thesis topics. In my first term as a graduate student, I came across the intellectual historian Quentin Skinner and his insistence that historians of his stripe seek out the intention of a text's author. Here was my niche. Further, in establishing the contexts in which my author-here, Muris - could reasonably have expected to be understood, I was able to cast my net wide. To attempt to identify his intentions meant investigating Muris, the historical actor who lived and breathed.

One major challenge that I faced in writing this thesis, a challenge I feel I met with limited success, was to limit its scope. The attempt to identify an author's intentions is inherently a willful jump into a bottomless well. In researching the contexts of Muris's early life, I wanted to paint as vivid a picture as possible. The difficulty with this approach is twofold: Much of this information will not be directly relevant to a sufficiently narrow thesis. Conversely, what is included will necessarily be abbreviated. These conditions invite the very real possibility that the resulting account will be at once overly expansive and disappointingly brief. A similar issue arose with my analysis of the Notitia. My original intention was to focus almost exclusively on its first book, because it contains key insights into Muris's intentions and has been all but ignored in the 
scholarship. It is my contention that we cannot understand the Notitia without considering both of its books. That is, they are two parts of a whole, not separable entities. My idea in focusing on Book I was to correct the imbalance in the scholarship, but by my own reasoning this analysis would be incomplete without including both books (regardless of the extent to which the second has been studied). Much of the value in studying Book I lies in identifying the ways in which its contents set up, frame, and interact with the contents of Book II. My solution to this dilemma was a compromise whereby my analysis of Book II is somewhat cursory, dealing primarily with those points of contact and interdependence. While writing my selective account of Book II, a task that proved more difficult than I had anticipated, I was drawn to Ptolemy's Almagest, the preeminent authoritative text on mathematical astronomy in Muris's day. There, late in the writing process, I found ideas that were, it seemed to me, reflected in the Notitia. These ideas not only demanded to be included in my thesis, but they required a substantial shift in its argument. So I followed the evidence, even at the expense of a concise thesis. My intention in this discussion has not been to discount my own scholarship or suggest that it fails in any substantial way but rather to be forthright about its potential excesses and limitations. In my defense, I call upon the words of Johannes de Muris himself: "It is not possible for the mind of one man, unless he have an angelic intellect, to comprehend the whole truth of any science."2

I would like to return for a moment to the contexts of Muris's early life and my decisions about what to include. The first pages I wrote for this thesis were what

\footnotetext{
${ }^{2}$ McKinnon, Source Readings, 159. "In capite unius hominis non est possibile, nisi intellectum habeat angelicum, totam cuiuslibet scientiam quiescere veritatis." Michels, Notitia, 106.
} 
eventually became Chapter Three, though in a form half the current length. It was my first real exploration into the life and times of Johannes de Muris. In the process of researching, I made a key realization that became a theme in that paper: Muris's years at the University of Paris corresponded exactly with the Dantean anomaly, a period of brutal weather that precipitated the Great Famine and intense inflation. This seemed significant to me. Although I could draw no direct causal connections between these events and his music theory, they were pervasive enough to have dramatically colored Muris's experience and occupied his mind. Little did I know how relevant this connection was. As I moved into my third year of graduate work and began writing in earnest, the world was plunged into a pandemic that not only disrupted everyday life but also inspired anxiety and fear, a general uneasiness about the world and its future. These anxieties were soon compounded by civil unrest and a decided threat to my country's democracy. Experiencing the difficulty of focusing on an academic project while the world seemed to be falling apart around me has caused me to reflect on Muris's experience and accomplishments. We all deal with catastrophe and trauma in different ways. Did he respond to those disruptions and uncertainties by throwing himself into his work? Did the sight of the starving poor and the effects of the tumultuous economy on his personal finances cause him to redouble his efforts in a bid to stave off the possibility of his own financial ruin? And what of wealth disparities? How different would his experience—and intellectual achievements—-have been, given different personal financial resources? There was no room in this thesis to substantially address these questions, but they beg consideration. 
That Muris and I both wrote our works in times of crisis or catastrophe is one parallel in our experiences. Please forgive the appearance of arrogance if I suggest that there is also a parallel between his Notitia and my thesis. In very general terms, both can be thought of as works of synthesis. As I describe in my conclusion, much of the brilliance of the Notitia is in its use of firmly established concepts to arrive at a new (dare I say revolutionary?) idea. Without the laudatory tone, this description fairly serves what I have done in this paper, which is built upon the distinguished and vetted work of other scholars. As its title suggests, the contribution of my thesis lies in the provision of a new perspective. A simple shift in perspective can lead to new vistas. That is my hope for this thesis.

I will end here with another quote from Muris, this one directed toward any musicologists who may appraise my efforts: "If these few things which we have said include anything that seems to be inconsistent with the truth, we ask you, venerable musicians (you in whom we have delighted from earliest youth because of music ... ), how far, from love of this work, you will correct and charitably tolerate our defects." ${ }^{3}$

\footnotetext{
${ }^{3}$ McKinnon, Source Readings, 158. "Illa tamen pauca, quae dicta sunt a nobis, si aliquid includant, quod videatur inconsonum veritati, vos rogamus, venerabiles, musici, quos a tota dileximus iuventute ratione musicae, quam qui bene sciret cum aliqua scientia non lateret, quatenus huius laboris amore defectus nostros corrigere velitis et benigne supportare." Michels, Notitia, 106.
} 


\section{Chapter One}

Introduction

Jehan shivered and pulled his cloak tight around himself. He rubbed his hands together in his lap, but discreetly, to avoid distracting the other scholars, who were intently listening to the lecture. The master was reading Aristotle's Physics. "Cum prius et posterius est," he was saying, "tunc dicimus tempus; hoc enim est tempus: numerus motus secundum prius et posterius." The master was speaking rapidly, but Jehan had no problem following along. He had heard this one before. In fact, he almost had it memorized. He mouthed the next words along with the master: "Non ergo motus tempus est sed secundum quod numerum habet motus. "Jehan looked to his side at the scholar freezing in his meager cloak and silently thanked God he wasn't poor himself, especially right now. He wondered if this meek student understood the significance of what the master was saying. This business about time being the number of motion in respect of 'before' and 'after' was tricky stuff. Letting his mind wander momentarily, Jehan thought back to the summa he'd been studying that quoted this exact passage in claiming that harmonious time was like natural time. He smiled to himself at the thought that he had found the key to measured music. And it was so simple, too.

Johannes de Muris was a Norman mathematician, astronomer, and music theorist active in and around Paris in the first half of the fourteenth century. ${ }^{1}$ He attended the

\footnotetext{
${ }^{1}$ In the scholarship he is also referred to as John of Murs, Jean de Murs, Jean des Murs, Jehan des Murs, and Jehan de Meur. Although it is perhaps too formal for the light in which I will be attempting to paint him, I have chosen to use the name found in the manuscripts, although I typically reduce it to the simple
} 
University of Paris (c. 1312-1321), where he received his master of arts degree.

Throughout his career, he resided primarily in Paris (where he had associations with the Collège de Sorbonne) and Évreux (at the cathedral church and as a clerc in the household of Philippe d'Évreux), though he also lived for a short time at the double monastery of Fontevrault and later in his life was a canon at the collegiate church in Mézières-enBrenne. ${ }^{2} \mathrm{He}$ was a dedicated scientist and prolific writer. Of the twenty works that have been solidly attributed to Muris, three dealt with music, seven with mathematics, and ten with astronomy. According to historian of astronomy Emmanuel Poulle, in Muris we see "the scientific character of an outstanding mind." ${ }^{3}$ Although he did not rise to the same heights as John Buridan or Nicole Oresme, Muris made a name for himself and circulated in elite society. He observed the solar eclipse of 1333 in the company of Jeanne II, queen of Navarre and daughter of a French king, ${ }^{4}$ and in the fall of 1344 received a letter from Pope Clement VI asking that he make his way non postponas to Avignon to discuss badly needed calendrical reform. ${ }^{5}$ His innovative work on the Alfonsine tables, versions of which became the dominant astronomical tables up to the time of Copernicus, has been recognized as playing "a decisive role" in their transmission. ${ }^{6}$ In speaking of Muris's

\footnotetext{
(though ungrammatical) "Muris." I have been calling him that for so long now that it feels comfortable and familiar.

${ }^{2}$ Gushee, "New Sources," 12 (also, 15-18); 12 and 15; 26; 14; and 8-9 (also, 19-20).

${ }^{3}$ Poulle, "John of Murs," 130. Poulle was here speaking of Muris's many astronomical observations, which were quite rare in this period.

${ }^{4}$ Gushee, "New Sources," 15.

${ }^{5}$ Nothaft, "Science at the Papal Palace," 277. Unfortunately, this reform did not come to pass.

${ }^{6}$ Chabás and Goldstein, "John of Murs's Tables of 1321," 318. In the words of E. Poulle, "the purpose of the Tables is ... [to] enable the practicing astronomer, at all times, to calculate planetary longitudes." "The Alfonsine Tables," 99. The Alfonsine Tables were produced in Castile by Judah ben Moses ha-Cohen and Isaac ben Sid, Jewish scholars under the patronage of Alfonso X of Castile (r. 1252-1284). For the Castilian tables and their Parisian reconfigurations, see Chabás and Goldstein, Alfonsine Tables of Toledo.
} 
influence on the music theory of the fourteenth and fifteenth centuries, musicologist Lawrence Gushee wrote that it "is so pervasive that it would be more feasible to deal with those writers who show no dependence on him than with those who do."7

This thesis will explore the life of Johannes de Muris up until he was about twentyfour years old, when he wrote his first work, the Notitia artis musicae (1319). ${ }^{8}$ Starting with the fragments of his biography that have been mined from the sources, we will draw on the vast historiography of the late Middle Ages to recreate an image of his experience in much the same way as a restoration specialist repairs a damaged photo. ${ }^{9}$ Our story will include Muris's homeland, his student experience and education, the Parisian musical culture he encountered, and the disastrous climate anomaly and famine concurrent with his university years. We will then turn to the Notitia, his compelling treatise that rationally explained the principles of polyphony. ${ }^{10}$ In the Notitia, Muris reconceived the existing notational system on a mathematical foundation. Although harmonics had been treated

\footnotetext{
${ }^{7}$ Gushee, "Muris, Johannes de," 412.

${ }^{8}$ In the earliest manuscript copy of this treatise (BnF lat. 7378A), the title Ars nove musice appears toward the end with the incipit "In arte (nostra) hec inclusa sunt aliqua." Gushee, "New Sources," 6. Karen Desmond has convincingly argued that this section of the treatise is an independent work (which she calls Conclusions) either distinct from or appended to the original treatise. Desmond, Music and the moderni, 28-31. Consequently, I will not be including it in my analysis, nor will I use the title Ars nove musice. Ulrich Michels gave the treatise the name Notitia artis musicae in his 1972 edition. He derived this title from a passage in Muris's Canones tabule tabularum (1321), in which he lists a number of his accomplishments from that year, including that "there became clear to us the knowledge of the art of producing and notating music." See ibid., 86, and n. 476 below. Although it is far from clear that Muris was referring to a specific work, let alone our treatise, the name has become standard in the literature, and I will be using it here to avoid confusion. Also in BnF lat. 7378, the year 1319 appears with the incipit "Quoniam in antepositis sermonibus theoricam [sic] musice," which marks the beginning of Book II. Gushee, "New Sources," 12. No other manuscript copy contains a date.

${ }^{9}$ Note from the author on the use of the first person plural in these pages: A text alone is silent. It only comes to life in the mind of the person reading it. This is a collective and participatory experience between you, the reader, and me, the writer.

${ }^{10}$ Polyphony, as opposed to monophony, refers to music that fits together multiple rhythmically distinct melodies. With an increase in rhythmic complexity comes an increase in the need for precision in its notation in order for the various melodies to remain synchronized. See Chapter Three, pp. 66-68, regarding this process in the early fourteenth century.
} 
mathematically since the time of Pythagoras, and rhythm had been understood in metrical terms for nearly as long, Muris was the first to extend mathematical principles explicitly to the quantification of musical time. In our exploration, we will see in the Notitia the confluence of his academic interests: mathematics, astronomy, and, of course, music.

There have been two major influences on the methodology employed in this thesis, and their provenance reflects its interdisciplinary nature. Drawn from intellectual history and musicology, we can think of one as theoretical and the other as practical, respectively. In forming the perspective that I have selected, I have been inspired by Quentin Skinner's article "Meaning and Understanding in the History of Ideas" (1969). Philip Weller's article "Frames and Images: Locating Music in Cultural Histories of the Middle Ages" (1997) has informed the scope of my thesis. Both have contributed to my approach to the evidence.

In "Meaning and Understanding," Skinner attacks two prevalent methodologies in his field and then suggests a third. He condemns the approach that bases its analysis purely on the text itself and tends to look for certain timeless or universal ideas. ${ }^{11}$ Stripped of its context, the text under analysis is liable to yield for the historian precisely what is sought after. $^{12}$ Also (paradoxically?) problematic is the methodology that looks for the meaning of a text through a study of the context in which it was written. While Skinner admits that placing a text in its given context is important for understanding its meaning, understanding the conditions of an action does not sufficiently explain its intention; that is, the danger of this approach lies in mistakenly assuming that the conditions determine the meaning of the

\footnotetext{
11 Skinner, "Meaning and Understanding," 4.

12 See ibid., 4-39.
} 
text. ${ }^{13}$ Context, he argues, should rather function as a "framework" for understanding the range of meanings a particular society would recognize and understand, which in turn will aid in "decoding" the author's intention. ${ }^{14}$ In his conclusion, Skinner states: "Any statement ... is inescapably the embodiment of a particular intention, on a particular occasion, addressed to the solution of a particular problem, and thus specific to its situation .... Texts cannot be concerned with our questions and answers, but only with their own." 15 In "Frames and Images," Weller stresses the importance of selecting an appropriate frame for a chosen subject. Explicitly delimiting the boundaries of a project has the advantage of narrowing the focus of the research and prioritizing the issues at play as well as signaling to the reader the respective relevance of those issues. In selecting a frame, he warns, one must be aware of the potential of these boundaries to obscure connections the subject may have with other avenues of life. The challenge lies in the balance of "internal connections" and "external relationships." 16 Weller also speaks to the illusory task of recreating the felt or perceived reality of a distant past. ${ }^{17}$ This is not to say, however, that the attempt to connect with the past should not be undertaken simply because it is prone to error. Rather, historians need to be explicit with their readers about the "sliding scale of historical reliability or fidelity."18 Finally, historians must be flexible and responsive to the evidence they find, lest the story tell more about its author than the subject. ${ }^{19}$

\footnotetext{
${ }^{13}$ Ibid., 39-48 and 49.

14 Ibid., 49.

15 Ibid., 50.

16 Weller, "Frames and Images," 13-14.

17 "If we wish to ask what it 'felt like' to be a medieval man or woman we might with equal justification ask what it feels like to be anybody else at all, even in our own time." Ibid., 46.

18 Ibid., 47.

19 Ibid.
} 
For this thesis, then, I have chosen a relatively narrow frame, only the first stage of Muris's life and one treatise. This has allowed me to be more comprehensive in my coverage of various contexts within those years, which in turn provided a greater opportunity for discovering interrelationships and connections in Muris's life and work, a driving force in the conception of this project. Yet within this limited scope, choices had to be made about which avenues to pursue, and consequently I have not included the rather large topics of politics and religion. ${ }^{20}$ Having selected a set of contexts that I thought would most effectively establish a generalized account of the conditions of Muris's life and curriculum, each became its own small research project based on secondary sources. In this process, I also considered the ways in which Muris would not have fit the mold of an average university student. The sum of these contexts helps establish Muris in a specific time and place and forms part of the framework in which to decode his intentions in the Notitia.

My analysis then turned to the text of the Notitia artis musicae itself, which is arranged in two books, Musica theorica and Musica practica. I began by translating Book I from the Latin (see Appendix). It starts with a short prologue in which Muris presented his epistemological stance and a blueprint for understanding the Notitia. I let his own words be my guide as I traced this stance through both books. I also identified the sources of the structures and concepts that Muris referred to and used and then determined how he was using them and how they had been used in the past. This could then be incorporated into what I had learned from his prologue. Further research on contemporary astronomical

\footnotetext{
${ }^{20}$ Much like family reunion etiquette. Moreover, Muris's Christological references in the Notitia are surprisingly minimal.
} 
practices revealed insightful correlations with Muris's presentation in Book Two. I then turned to Ptolemy's Almagest, which I had encountered in researching Muris's astronomical education. There, in Ptolemy's ontology, I found the missing link in Muris's epistemology that explained its divergence from the Aristotelian model on which it was based. I was then in a position to analyze the Notitia within the framework of the contexts I had established.

I will argue that: (1) With the Notitia artis musicae, Johannes de Muris responded to a need in the musical community in Paris. As Muris saw it, that need was not for a justification or even codification of current practice but rather for a comprehensive theory of mensural notation built on a speculative foundation that, responding to Aristotelian epistemological requirements, gave a rational, 'scientific,' explanation of the art (ars) of musica mensurabilis. ${ }^{21}$ (2) Although Muris inherited the basic criteria for his epistemology from Aristotle, it was Ptolemy's ontological grouping of motion and time into the category of mathematical objects that allowed Muris to use mathematics in his investigation of the measure of musical time. (3) In turn, the methods of mathematical astronomy provided Muris the means for achieving the precision and flexibility required of a comprehensive notational system. (4) It was also from Ptolemy that Muris derived his conviction that an ars could be improved upon over the course of generations. (5) This improvement was contingent upon continued observation of the subject being investigated, and it is in this light that we should consider the role of contemporary practice as a motivating factor in the conception of Muris's mensural theory. The new rhythmic subtleties that Muris observed were analogous to empirical data, which required reasoned assessment based on established

\footnotetext{
${ }^{21}$ Musica mensurabilis, or "measured music," was the branch of practical music that dealt with polyphony and its notation.
} 
principles. (6) Muris considered the Notitia a mathematical work that advanced the ars of musica mensurabilis. As such, it can be seen as a means for advancing his own career, as it held the promise of establishing him as a capable and innovative mathematician.

To understand the advantages of this approach and the value of its conclusions, we must make a brief survey of the existing literature in which Muris is found. Although he is not prominently placed, Muris was included in the volumes of the history of science of earlier generations. Lynn Thorndike and Marshall Clagett, to name just two scholars, both found room for our "eminent Parisian mathematician and astronomer" in their histories. ${ }^{22}$ Recently, historians of astronomy José Chabás, Bernard R. Goldstein, and Matthieu Husson have done much to illuminate our understanding of Muris's astronomical contributions and methods. ${ }^{23}$

It will come as no surprise that medieval musicologists have long been aware of and studied Muris's musical treatises, particularly the Notitia artis musicae, which had a significant effect on the musical style known as the ars nova. ${ }^{24}$ In earlier musicological literature, however, Muris tended to be overshadowed by the grandeur of Philippe de Vitry (1291-1361), whose impressive career, known musical compositions, and supposed theoretical writing have made him an enticing subject of study. ${ }^{25}$ Thanks in large part to Lawrence Gushee, who did much of the early legwork in searching out and assembling

\footnotetext{
${ }^{22}$ Thorndike, Magic and Experimental Science, 3:294-324 and throughout. Also mentioned in vol. 4; Clagett, Science of Mechanics, 113-35, quote at 120.

${ }^{23}$ For Chabás and Goldstein, see bibliography; Husson, "Complex Computational Practice."

${ }^{24}$ Ars nova is the name given to the predominant style of French literate polyphony of the last threequarters of the fourteenth century. It was characterized by its rhythmic complexity and schematic structure. See my introduction to Chapter Two.

${ }^{25}$ Bent and Wathey, "Vitry, Philippe de," Grove Music Online. https://www.oxfordmusiconline.com/grovemusic/view/10.1093/gmo/9781561592630.001.0001/omo9781561592630 -e-0000029535.
} 
Muris's biography, this disparity has been more or less rectified. ${ }^{26}$ The discipline of musicology clearly has its own set of foci centered on the development and function of musical styles. Consequently, musicologists have understandably directed their attention to Muris's contribution in those areas, often only mentioning (and sometimes ignoring) the fact that he was a mathematician and astronomer. At the same time, the scholars in that discipline deserve much credit for the seriousness with which they take the historical element of their research. Recognizing a scholastic bent in much music theory from the second half of the thirteenth century through the fourteenth as well as the rise of Aristotelianism in the universities that occurred simultaneously, many musicologists have situated their understanding of the music of this time in front of a university backdrop. Since the 1990s, musicologist Dorit Tanay's work has concentrated on reversing this perspective, placing the intellectual concerns of the university in the foreground (see Chapter Two). Her work has taken an interdisciplinary approach to the study of medieval music theory, which has done much to illuminate the intellectual context of Muris's musical writing and situate it within a mathematical avant-garde. In the past few years, Karen Desmond has incorporated the scholarship of historians of astronomy in her studies of Muris in the context of the ars nova. This has yielded insights into his character and working methods and adjusted our understanding of the contours of his career but revealed no concrete influence of astronomy on Muris's music theory. ${ }^{27}$ In 2017, Desmond helped organize a one-day interdisciplinary workshop that focused on Muris as a quadrivial

\footnotetext{
${ }^{26}$ See Gushee, "New Sources," and "Murs and his Milieu."

${ }^{27}$ Desmond, Music and the moderni, 85-102.
} 
scientist. ${ }^{28}$ That event points to exciting new developments in the cooperative study of his work.

Regrettably, music, to say nothing of Muris, is rarely incorporated into generalist studies of the Middle Ages. One of the few exceptions is Alex J. Novikoff's The Medieval Culture of Disputation: Pedagogy, Practice, and Performance, in which one section of a chapter is dedicated to an analysis of the way that scholastic disputation infused itself into the medieval motet, chanson, and jeu-parti. ${ }^{29}$ However short, the inclusion points up the potential usefulness of integrating musical studies into our descriptions of medieval culture. Interconnections abound.

Historian Alfred W. Crosby's book The Measure of Reality: Quantification and Western Society, 1250-1600 stands out for its exemplary—if flawed—use of a wide variety of disparate scholarship, including musicological studies, in the service of a broad, generalist narrative. In this monograph, Crosby looks to isolate the fundamental shift in perception, or mentalité, that allowed for "the amazing success of European imperialism." What he finds is that between the years 1275 and 1325, a "marked shift" started Europe down the path of quantification, which led it "to bring mathematics and measurement

\footnotetext{
${ }^{28}$ Jean (Jehan) des Murs: Quadrivial Science in the Fourteenth Century, Thursday, June 15, 2017, at All Souls College, Oxford. "The event brought together musicologists, historians of astronomy, and other experts interested in Jean's leaned activities, all of whom were encouraged to communicate their results across disciplinary boundaries and thereby contribute to a greater integration of current and future scholarship on this important fourteenth-century figure." Nothaft, Desmond, and Husson, "Murs's Quadrivial Pursuits," 4. I was in the middle of the first year of my graduate program when this event took place but unfortunately did not find out about it until over a year later. It still pains me deeply that I was not able to attend.

${ }^{29}$ Novikoff, Medieval Culture of Disputation, 147-55.

${ }^{30}$ The very premise of this book, with its seeming invocation of European chauvinism, quite understandably raised more than a few eyebrows. For a defense of the question "why the West?" and The Measure of Reality, see Jacob, "Thinking Unfashionable Thoughts." For a strong critique, see Hart, "The Great Explanandum.”
} 
together and to hold them to the task of making sense of a sensorially perceivable reality."31 Crosby fits music into this story, dedicating an entire chapter to it, where he discusses the ars nova and even mentions Muris. ${ }^{32}$ Its thesis is that in the fourteenth century "the writer of music achieved control over the fine detail of sound, a physical phenomenon, moving through time." ${ }^{133}$ Although this is an excellent point that lends itself well to Crosby's broader thesis, it misses an even more relevant observation: the Notitia describes musical sound as a physical phenomenon moving through time that can be analyzed mathematically.

Crosby has shown that music has a place in the history of science and technology, a place further solidified by closer study of the Notitia. Historians of science have recognized Muris's contributions to astronomy. They have also long noted the exceptionalism of astronomy for its dedication to observation and precise measurement. ${ }^{34}$ But rarely has it been credited for its contribution to the empirical science of the seventeenth century. My thesis demonstrates the way in which Ptolemaic ontology led to the mathematical description of musical sounds considered as physical phenomena, suggesting further avenues for exploring the development of Western science while taking into account the exchange of ideas across disciplines. ${ }^{35}$

${ }^{31}$ Crosby, Measure of Reality, 18 and 17.

32 "Johannes de Muris, mathematician and astronomer as well as musical theorist, wrote another treatise just about this time, possibly even more influential than Philippe [de Vitry]'s, with a nearly identical title, Ars nove musice." Ibid., 154. See n. 8 for the title of the Notitia.

${ }^{33}$ Ibid., 157.

${ }^{34}$ According to A. C. Crombie, "until the seventeenth century, astronomy was far ahead of all other theoretical sciences in the extent to which it was accurately and systematically quantified with actual measurements." "Quantification in Medieval Physics," 156.

${ }^{35}$ This theme is explored in Peter Pesic's book Music and the Making of Modern Science (Cambridge, Mass.: MIT Press, 2014). 
Although the present work primarily engages with themes found in the musicological literature, it also draws substantially from the histories of astronomy and philosophy. If these are the bones of my thesis, I have given it flesh from the scholarship on climate, Normandy, travel and relocation, urban life, university culture, and education. Placing the emphasis on Muris himself and his intentions - in the context of his life as a university student—will provide a point of engagement in which those specialized themes can been seen not as isolated or abstract concepts but as practical concerns. This approach reminds us that the intellectual elite also navigated through a physical world. It demonstrates that despite the convenience of neat disciplinary boundaries, ideas are fluid and will go wherever they are needed or called upon.

As this thesis is in large part a work of synthesis, it will be particularly important to review in some detail the scholarship on which it is built. Chapter Two will introduce the reader to the subset of musicological literature beginning in the late 1950s that deals with the intellectual context of late thirteenth- and early fourteenth-century mensural theory. While early scholarship focused on establishing these texts as university products, substantial later insights have demonstrated that musica mensurabilis was not taught in the university at this time. The emphasis of inquiry has subsequently shifted toward a more nuanced inspection of the influence of Aristotelianism and the university curriculum on the form and content of late-medieval music treatises. This scholarship ranges from the extremely erudite to the refreshingly pragmatic. Beyond its function as a literature review, this chapter will introduce many of the concepts central to my thesis and the scholars to whom I am most indebted. 
Having reviewed the relevant scholarship on the intellectual context for the Notitia, we will move to a biographical approach. Chapter Three will provide an in-depth account of the life of Johannes de Muris up to the point at which he wrote the Notitia artis musicae, telling the story of the young scholar's move to Paris and the life he found there. This work of historical imagination, which applies the general and known to the specific and unknown, will serve two goals: It will establish Muris in a particular time and place, giving an idea of what his life was like and what kinds of activities filled his days, and it we will uncover key insights into his experiences and character that will later be shown to have had an impact on his music theory.

In Chapter Four, we will turn to our central document, the Notitia artis musicae, taking its two books as equally significant parts of a whole. A close analysis of Book Ithe first of its kind - will reveal critical insights into Muris's intention in writing the Notitia. Central to this analysis is the crucial role of his epistemological stance, or "philosophy of science," which owed as much to Ptolemy as it did to Aristotle. Muris refashioned his source material for Book I, Boethius's De institutione musica, to reflect this epistemology and lay the groundwork for the speculative reconception of musica mensurabils that he presented in Book II. This theory, which is characterized by the mathematical function of its musical notation, employed methodological procedures Muris adopted from the practice of astronomy. The Notitia is a strong work of synthesis, in which Muris deployed all of the analytical tools at his command. 


\section{Chapter Two}

The Intellectual Foundations of ars nova Music Theory, a Historiography

"This cantus [motet] ought ... to be celebrated in the presence of . . the educated and of those who are seeking out subtleties in the arts." ${ }^{136}$

As the following literature review covers a specialized subset of a specialized field, a brief primer may be in order. ${ }^{37}$ The subject under discussion here, in its most general sense, is European literate polyphonic music and the systems designed to notate it. Literate polyphony developed as an adornment to chant, whereby a second voice was added at a different pitch, thus creating a harmony. As this music expanded in melodic and rhythmic complexity, new forms of notation were devised to ensure the lines remained synchronized. The pace of development quickened in the thirteenth century, and at around mid-century, a series of theorists produced more precise and flexible notational schemata. The more complex polyphony, epitomized by the motet, was known as musica mensurabilis ('mensural music' or 'precisely measured music'), and the writing that describes its notation is now known as mensural theory. These terms cover all precisely notated music during our period. Composers continued to innovate, and a new style began to emerge in the late 1310s, led by Philippe de Vitry. It was accompanied by the dramatic leap in notational precision found in the Notitia artis musicae of Johannes de Muris. This new musical style

\footnotetext{
36 "Cantus autem iste non debet coram vulgalibus propinari. Eo quod eius subtilitatem non advertunt nec in eius auditu delectantur. Sed coram litteratis et illis qui subtilitates artium sunt querentes." Grocheio, Ars musice, 84-85. See below, Ch. 3, pp. 68-69, for a discussion of this quote.

${ }^{37}$ For an excellent overview of this entire history in a single volume, see Taruskin, Music from the Earliest Notation.
} 
and its notation are known as the ars nova, and the older style that flourished in the second half of the thirteenth century became known as the ars antiqua or ars vetus.

That the polyphonic innovations emanating out of Paris c. $1250-1350$ were a product of an intellectual milieu with connections to the university-and its concomitant Aristotelianism — has long been a trope in medieval musicology. A short sampling of chapter titles from some major surveys are sufficient to demonstrate this point: "Music for an Intellectual and Political Elite: The Thirteenth-Century Motet"38 and "The Polyphonic Music of the Medieval Monastery, Cathedral and University." ${ }^{39}$ Likewise, the now generation-old standard, Ars Nova and the Renaissance: 1300-1540, claims in its introduction that "the influence of Aristotelian thought, the growth of empiricism, the need for 'imitation of nature,' make themselves felt in music as in the other arts and fields of European thought." 40 This sentiment was echoed, in an equally cursory fashion, thirty years later: "The Parisian motet shows every sign of being a university product, and this helps to explain the curious contrast between the licentious frivolity of most of the texts and the rigorously academic techniques with which they were set." ${ }^{41}$ While there is much truth in these observations, under the surface of the survey one finds a more complex and contentious discussion of this topic.

\footnotetext{
${ }^{38}$ Ibid., 207-46. While the word university does not appear in the chapter title, its opening words read, "the rise of the university produced a new class, emanating from Paris, of literati."

${ }^{39}$ Gushee, "Polyphonic Music," 143-69. It should be noted that this article does little to situate the study, proliferation, and enjoyment of polyphony within a university context. Unsubstantiated sentences like this one epitomize the treatment of this issue in the non-specialist literature: "That music was another important area of specialization in Paris is abundantly clear from the numerous documents, both verbal and musical, which have survived" (157). Cf. this rather more cautious assessment: "The scholasticism of Parisian thinkers at the time affected the cast of some music theoretical writings." Pesce, "Theory and Notation," 282.

${ }^{40}$ Hughes and Abraham, Ars Nova and the Renaissance, xviii.

${ }^{41}$ Leech-Wilkinson, "Ars Antiqua-Ars Nova-Ars Subtilior," 220.
} 
The study of late-medieval literate polyphony has engendered two distinct yet related sub-topics concerning the role of the university in its development: the place of music in the university curriculum and the influence of university teaching on the form and content of music theory. As the field has evolved and certain issues have been resolved, recent scholarship has begun asking questions about the intellectual context of this music and its theory outside the confines of these sub-topics. In this chapter, we will consider this literature in roughly chronological order, though some allowances will be made for the sake of topical discussion. Further, although a connection to the university was the path by which scholars began their search for an intellectual context of polyphonic innovation, the present thesis takes this connection, as it stands in current scholarship, as one piece of a larger puzzle.

In 1954, Nan Cooke Carpenter published her article "The Study of Music at the University of Paris in the Middle Ages," in which she argued that although "medieval statutes for the university offer little information ... about actual subjects of instruction, there is overwhelming evidence from many other sources for the study, cultivation, and practice of music as science and art at the great French University." ${ }^{142}$ In her subsequent monograph on the subject—which expands its purview to the universities of Europe in the Middle Ages and 'Renaissance' - Carpenter extended the coverage of music at the University of Paris to include the study and development of polyphony, "directly or

\footnotetext{
${ }^{42}$ Carpenter, "Music at the University," 136-44.
} 
indirectly." ${ }^{13}$ As we will see below, Carpenter's confident assertions have been significantly challenged.

Working from the assumption that early mensural (precisely measured) music theory was a product of the university, ${ }^{44}$ Jeremy Yudkin called attention to the use of Aristotelian terminology in the music treatises produced in Paris in the second half of the thirteenth century. In "The Influence of Aristotle on French University Musical Text" (1990) Yudkin made what he called a 'simple' argument: "We cannot fully understand the writings of thirteenth-century theorists on music, unless we appreciate the extent to which they incorporate the vocabulary, logical systems, and modes of thought of Aristotelianism." ${ }^{145}$ Although Yudkin clearly identifies these theorists' use of Aristotelian systems of classification (e.g. division of genus into species), terminology (e.g. modus, aequipollentia, organon), and methods (e.g. the four causes of reality—formal, material, efficient, and final), he does little to explain how this recognition "can lead us not only to a greater understanding of the meaning of those texts, but also to an understanding of what those texts actually are."16

\footnotetext{
${ }^{43}$ Carpenter, Music in the Medieval and Renaissance Universities, 55. The full quote runs thus: "In view of the development of new forms of polyphony at Notre Dame in the late Middle Ages, the close connection between musical officials in the cathedral and university personnel, and the constant supply of students from the choir school to the university, it is not surprising that many treatises on artistic aspects of musica practica sprang, directly or indirectly, from musical studies at the University of Paris - treatises attempting to solve the problem of a clearer system of notation, attempting to evolve an unequivocal basis for rhythmic values resulting in the standard mensural system, and discussing the various forms of the new polyphony, discantus."

${ }^{44}$ Although Yudkin acknowledges that Boethius's De institutione musica was the "official text book on music in the middle of the thirteenth century," he does not further pursue the question of polyphony's place in the curriculum of medieval universities. Yudkin, "Influence of Aristotle," 181.

${ }^{45}$ Ibid., 178.

${ }^{46}$ Ibid., 185.
} 
The influence of scholastic education on medieval music theory has been most thoroughly explored by Dorit Tanay. ${ }^{47}$ Building on themes she developed in her dissertation, "Music in the age of Ockham: The interrelations between music, mathematics, and philosophy in the fourteenth century" (1989), she went on to explore how the mensural theory of the early fourteenth century differed from that of the late thirteenth as a result of the intervening changes in scholasticism. "The Transition from the Ars Antiqua to the Ars Nova: Evolution or Revolution?" (1992) is a reaction to "recent studies"48 which deny the revolutionary nature of the ars nova, and its goal is to "rehabilitate the traditional conviction by pointing to the radically new elements in the music theory of Jehan de Meur's Notitia artis musicae." ${ }^{19}$ The first half of her argument is dedicated to an investigation of the ways in which ars antiqua theorists incorporated Aristotelianism into their conceptions and expositions of 'measured' music. ${ }^{50}$ Critically, she points out tensions between the need for "a quantitative numerical analysis" in mensural theory and the qualitative analysis demanded by Aristotle. ${ }^{51}$ One of the strategies Tanay illuminates was the conception of the two note shapes, longa and brevis, as "a relation between opposites." ${ }^{52}$ A somewhat later

\footnotetext{
${ }^{47}$ See bibliography.

${ }^{48}$ In "A Phantom Treatise of the Fourteenth Century? The Ars Nova" (1985), Sarah Fuller argued against a notion that had become common coin in musicological scholarship, that Philip de Vitry wrote a treatise on ars nova theory. Although Vitry's prominence as an ars nova innovator is well-attested in the primary sources, Fuller found lacking the evidence for a treatise under his authorship, arguing instead that the group of divergent treatises thought to be witnesses to a non-extant urtext are in fact representatives of a "teaching tradition." For Fuller, the assumption that Vitry did not, in fact, write a definitive text that marked a clear delineation between an ars vetus and ars nova in late-medieval music lends credence to the hypothesis that they "mesh in an unbroken continuum in which the nova is a complementary extension of the ars vetus" (47).

${ }^{49}$ Tanay, "Evolution or Revolution?" 79. Much of this material was later reworked and incorporated into Noting Music, Marking Culture, discussed below.

${ }^{50}$ Ibid., 81-90.

${ }^{51}$ Ibid., 81-82. See especially n. 8. Tanay points out the concomitant tensions between Aristotelianism and Christian doctrine (n. 12).

${ }^{52}$ Ibid., 84 . This theory was developed by the 'pre-Franconians.'
} 
solution was introduced by Franco of Cologne, who established 'perfection' and imperfection' as the governing opposites. ${ }^{53}$ For Tanay, this brings to mind the Thomistic notion of an imago Dei. ${ }^{54}$ In her telling, the world resembles its creator, God, in its beauty, goodness, and perfection. The result of Franco's insistence on musical 'perfection,' characterized by rhythms counted in threes, "guaranteed regularity and uniformity in rhythmic motion," which "imitates the immobile God and perfect circular, periodic cosmic motion." 55 For Tanay, what separates ars antiqua theory from that of the ars nova is that the latter sought to incorporate rhythmic irregularities into a broader understanding of order and perfection that more closely resembled the natural world. ${ }^{56}$ This change, she contends, reflects changing scholarly attitudes toward the quantification of qualities, beginning with Duns Scotus (1266-1308) and pursued most vigorously by a group of mathematicians from Merton College, Oxford, known as the Oxford Calculators. ${ }^{57}$ She then draws parallels between these developments and Johannes de Muris's insistence that all musical notes are of the same species and are measurable along the continuum of time and capable of being reckoned mathematically. ${ }^{58}$ In perhaps the weakest portion of her argument, Tanay then

\footnotetext{
${ }^{53}$ Ibid., 85-86.

${ }^{54}$ Ibid., 88.

${ }^{55}$ Ibid., 89.

56 "Jehan [de Meurs] laid the foundation for conceiving music as an imitation of an earthly, variable, imperfect process, rather than a divine perfection." Ibid., 90.

57 Ibid., 90-93. In an early note, Tanay is careful to make clear that there is no evidence of contact between Muris (or Meur) and the Mertonian mathematicians and that her intention is merely "to show a material and methodological relationship between Jehan de Meur and the Oxford Calculators, and not to prove any empirical-historical connection." Ibid., n. 2. However, despite indicating in this same note that "Jehan's Notitia of 1320 antecedes the earliest known sources of the Mertonian Calculators," she later uses language that obscures this chronology: "Jehan's reasoning ... may be construed as a reflection of Dumbleton's theory"; "his theory echoes the Calculator's insistence ..."; and "Jehan did not merely reflect the new mathematical trends of quantifying intensive magnitudes; he adopted them and spoke their analytical language." Ibid., 94, my emphasis.

${ }^{58}$ Ibid., 94-97.
} 
draws parallels between the Calculators' work in measuring variable rates of change with Muris's division of the longa. ${ }^{59}$ This despite the fact that, though conceived in "four divisions," it is purely arithmetical and describes only uniform qualities. ${ }^{60}$ The end of the article is dedicated to showing how Muris, though dedicated to the theological preeminence of 'perfect' (ternary) rhythmic division, went to lengths to show how the 'imperfect' could participate in the 'perfect' and how this corresponded to the Calculators' efforts to bring order to disorder in their quantifications of difform and irregular motion. ${ }^{61}$ Although the specifics of Tanay's argument raise questions and beg closer scrutiny, her position on the conceptual distinction between the ars antiqua and nova seems well-founded.

\section{In Discarding Images: Reflections on Music and Culture in Medieval France}

(1993), Christopher Page engaged with Tanay's approach to understanding the intellectual underpinnings of medieval mensural theory. Commenting on her dissertation, Page agreed that "a great deal of mensural theory produced during the thirteenth and fourteenth centuries is permeated by terms and concepts ultimately derived from Aristotle. It would be very surprising indeed if it were not." 62 Page, however, thought that Tanay took this too far. He saw much of the "Aristotelian complexion" of these treatises as "either heuristic or superficial (indeed cosmetic)." ${ }^{63}$ While medieval music theorists certainly employed Aristotelian concepts as explanatory aids, Page argued, it does not perforce follow that they

\footnotetext{
${ }^{59}$ Ibid., 97-99.

${ }^{60}$ Although latent in Muris's theory is the advanced concept of complex ratios, or ratios of ratios, by placing all possible note values on a number line, he has rendered those relationships arithmetical. Tanay makes no reference to the way Muris simultaneously expanded and simplified mensural theory.

${ }^{61}$ Ibid., 99-103.

${ }^{62}$ Page, Discarding Images, 121.

${ }^{63}$ Ibid.
} 
were "necessary conditions" for the innovations found in their theory. ${ }^{64}$ But Page does little more than question Tanay's premise, countering a number of her examples of Aristotelian influence with passages from sermons that he claims could just as easily have served as the antecedents. ${ }^{65}$ He does, however, propose a historical context for the mathematical bent of the ars nova: the rise in the importance of the skills of computus and algarismus for the clerical classes. ${ }^{66}$ This serves as a welcome counterpoint to Tanay's thesis, but it is hard to see how the two perspectives are mutually exclusive. Central to the disagreements between Tanay and Page are not only the different approaches to the subject but also the very different goals of these authors' scholarship. Whereas Tanay is interested in illuminating the intellectual context of the theoretical underpinnings of late-medieval music - it should be noted that this does not carry with it the implication that the intellectual context is the only context through which the music of this period could be studied and understoodPage's target is much larger. In Discarding Images, he questions the very way in which modern scholars characterize the Middle Ages and, in turn, its music. ${ }^{67}$ Page, as a musician

\footnotetext{
${ }^{64}$ Ibid., 122.

${ }^{65}$ Ibid., 122-24.

${ }^{66}$ Chapter 4, "Ars Nova and Algorism," in ibid., 112-39.

${ }^{67}$ See Weller, "Frames and Images." In this article, Weller intimately and fruitfully engages with Discarding Images, providing praise and critique, in an in-depth discussion of the methodological strategies historians have used to characterize the Middle Ages and the pitfalls and challenges through which historians need to navigate. Weller provides this summary of Page's argument: "In sum, Page wishes to challenge two crucial misconceptions in the way we frame our restrictive and generalized accounts of medieval culture: (1) we misguidedly assume that it does in fact have a definable —indeed, a lucidly structured, self-consistent and fully resolved - essence; and (2) we unquestioningly attribute to this essence a severely limited set of characteristics - 'cathedralist' culture, for example, is described as manifesting a dry analytic rationalism, a strong ascetic-intellectual bias, a preference for 'cellular' order and proportion, a symbolic or constructivist Pythagorean mind-set - and then marginalize anything that does not fulfill these criteria. As a result, a positive criterion of selection becomes a negative one of exclusion or ignorance" (30).
} 
and choir leader, is interested in music as a sensual experience, and, as its subtitle suggests, Discarding Images concerns itself with placing music in its cultural context.

In Noting Music, Marking Culture: The Intellectual Context of Rhythmic Notation, 1250-1400 (1999), Tanay reacted to Page's refutations of her thesis. Arguing that "discursive strategies cannot be exposed without reconstructing the formative milieu with which musical ideas were fashioned," Tanay sees in Page's assessment of a mere Aristotelian "complexion" a reaction to the treatises' rhetoric. ${ }^{68}$ For Tanay, the "philosophical, extramusical notions" in late-medieval mensural theory are too intertwined within their content to be dismissed. She sees this connection illustrated in the distinct philosophical strategies found in ars antiqua and ars nova theory, a distinction she accuses Page of failing to appreciate. ${ }^{69}$ This diachronic approach, sensitive to the nuances of an evolving scholastic worldview, is one of the major strengths of Tanay's work. ${ }^{70}$ At the heart of this is her conviction that ars antiqua theory was informed by and dependent on Aristotelian and Thomistic philosophy, ${ }^{71}$ whereas she characterizes the ars nova as "antiAristotelian." In Muris's use of mathematics to describe the physics of sound, Tanay sees a break with Aristotle's injunction against metabasis, whereby the principles of one science cannot be transferred to another. ${ }^{72}$

In Noting Music, Marking Culture, Tanay acknowledges the contribution of Yudkin's earlier efforts to identify the Aristotelian influence on late medieval mensural

\footnotetext{
68 Tanay, Noting Music, Marking Culture, 40.

${ }^{69}$ Ibid., 40-41.

${ }^{70}$ It may still be argued, as Page does, that Tanay "overplays her hand" and "shows a tendency to see the evidence of a scholastic mentality in everything she reads." Page, Discarding Images, 122.

${ }^{71}$ See Tanay, Noting Music, Marking Culture, 17-63.

72 See ibid., 67-181.
} 
theory but argues that "it does not go far enough. It is the historical significance-including the immediate effect and the future consequences - of basing a rhythmic theory on Aristotelian matrices that calls for an interpretive analysis." ${ }^{73}$ Indeed, Noting Music, Marking Culture goes far beyond "invoking concordances" and is an erudite exploration of "the impact of specific mathematical and philosophical doctrines on late-medieval reflections about the articulation of musical time and its representation." 74 As we will see, whether or not Aristotelianism contributed to the content of mensural theory remains an open question.

Having come some way in pursuing the question of scholasticism's influence on medieval music theory, we can now change tack and return to the question of music's place in medieval university curricula, particularly at Paris. Published alongside Jeremy Yudkin's "Influence of Aristotle," Michel Huglo's "The Study of Ancient Sources of Music Theory in the Medieval Universities" built upon the seminal efforts of Carpenter and others. ${ }^{75}$ While acknowledging their contributions, Huglo saw the need for a study that took into account "the texts taught during the first half of the thirteenth century [and] a statute of the Faculté des Arts listing the compulsory 'textbooks' assigned for the study of philosophy."76 In filling this lacuna, Huglo found that the liberal arts (including Boethius's De institutione musica) were taught at the University of Paris from its founding to 1255 , after which rhetoric and music were displaced by natural philosophy and "relegated to the background

\footnotetext{
73 Tanay, Noting Music, Marking Culture, 19.

${ }^{74}$ Ibid. Although Tanay scarcely mentions astronomy, a close study of late-medieval mathematics sits at the center of her "hermeneutical setting." Ibid., 3.

75 Huglo,"Ancient Sources," 150-89. See ibid., n. 1 for Huglo's "general bibliography."

${ }^{76}$ Ibid., 150.
} 
of university teaching." 77 This line of inquiry was taken much further by Gilles Rico, who in 2005 completed his dissertation, "Music in the Arts Faculty of Paris in the Thirteenth and Early Fourteenth Centuries," which queried examination compendia, 'textbook' glosses, commentaries on Aristotle, and scholastic questiones to ascertain the place of music at the University of Paris. ${ }^{78}$ Rico's approach to this material is systematic and critical and stands in sharp contrast to the arguments of Carpenter, whose "'overwhelming' evidence is nowhere to be found .... [and] eludes the question of the actual teaching of music in the Arts faculty of Paris." ${ }^{79}$ Rico finds that speculative music, as a branch of the quadrivium, was indeed taught at the university throughout the Middle Ages, focusing on the first two books of Boethius's De institutione musica, but it was a "secondary discipline taught on feast-days" and "occupied a limited place in the Arts curriculum." 80 Further, he finds no evidence for a praxis-oriented study of music and concludes that "the Arts faculty of Paris played at best an ancillary institutional and intellectual role in the emergence of measured polyphony." 81 The diachronic methodology with which Rico analyzes his material yields the dissertation's most enlightening discoveries. As the university absorbed and embraced Aristotelianism, the study of speculative music shifted away from arithmetic and toward questions of epistemology. Musica became defined as a "scientia media, partly physical and partly mathematical." ${ }^{82}$ This empirical approach to music, Rico observes, is evident in

\footnotetext{
${ }^{77}$ Ibid., 172.

${ }^{78}$ For Rico's excellent historiography, see "Music in the Arts Faculty," 1-6.

${ }^{79}$ Ibid., 2-3.

${ }^{80}$ Ibid., 299 and 300.

${ }^{81}$ Ibid., 299.

${ }^{82}$ Ibid., 301.
} 
the music theory of the very end of the thirteenth century into the fourteenth. ${ }^{83}$ Aristotelian influence on the music theory of the previous generation - epitomized by Franco of Cologne's Ars cantus mensurabilis — on the other hand was "employed either for purely decorative purposes or as illustrative parallels." ${ }^{14}$ Whereas Rico's conclusion that musical practice was never fostered at the University of Paris is well-demonstrated, his assessment of the influence of the university's Aristotelian curriculum on ars nova theory and its immediate predecessors is less definitively argued, and further debate appears warranted. Indeed, certain discrepancies emerge between the conclusions reached in Rico's dissertation and those found in Tanay's Noting Music, Marking Culture, which had appeared six years before. Tanay's insistence on the intellectual influence of contemporary scholastic concerns on the form and content of music theory, already dismissed by Page, seems to be one of the targets of Rico's claim that this influence "has been largely overestimated." 85 In fact, his assessment that "the idea that a praxis-oriented music theory was taught within the framework of the university underpins Dorit Tanay's recent study on

\footnotetext{
${ }^{83}$ Ibid., 303. "It now dealt with a newly constructed ambivalent subject matter determined formally by number and materially by sound. This model constructed through the teaching of music at the arts faculty of Paris was embraced not only by prominent music theorists such as Jacobus Leodiensis, Johannes de Muris, Johannes Grocheio and Henricus Helene who all certainly frequented the schools of the Rue $d u$ Fouarre at some point, but it would also remain influential for the centuries to come." In 2011, Catherine Jeffreys took issue with the common assumption that later medieval Parisian music theory was a product of the faculty of arts ("The Exchange of Ideas About Music in Paris"). She used as a case study Guy of SaintDenis's Tractatus de tonis (after 1301), which has been categorized by scholars as having been 'influenced' by Aristotelianism. Guy, however, cannot be situated in the arts faculty at Paris, and Jeffreys demonstrates that the treatise's Aristotelian citations and references were drawn exclusively from the works of Johannes de Grocheio and Peter of Auvergne and that "the opinions of Guy, Grocheio, and Peter about music were generated in places of learning in Paris other than the Faculty of Arts" (175). She concludes by suggesting that the colleges in Paris be considered as likely sites for the production of medieval music theory. Despite the value of this conclusion, it is significant that both Grocheio and Auvergne were trained in the faculty of arts, and the influence of that education on their music theory cannot be dismissed.

${ }^{84}$ Rico, "Music in the Arts Faculty," 306. For Rico's full exploration of the tentative connection between the arts faculty and the development of polyphony, see ibid., 238-99.

${ }^{85}$ Ibid., "abstract."
} 
the intellectual context of rhythmic notation in late medieval Paris" is wholly inaccurate. ${ }^{86}$ The most glaring discrepancy in these two scholars' work is found in their assessments of the influence of Aristotelianism on, in turn, ars antiqua and ars nova theory. As we saw, Tanay perceived in ars antiqua theory a full subservience to Aristotelian concepts whereas she identified ars nova theory as "anti-Aristotelian." By contrast, Rico agrees with Page in claiming that the Aristotelian terminology found in many ars antiqua treatises is evoked for "cosmetic" purposes.$^{87} \mathrm{He}$ does, however, also see a "didactical function" whereby the theorists employed concepts derived from grammar and Aristotelian logic to illustrate or clarify musical ideas. ${ }^{88}$ Critically, in Rico's view, these concepts, even when used didactically, are not fundamental to the theory and could be understood without a functioning knowledge of them. ${ }^{89}$ It is with ars nova theory, at least that of Johannes de Muris, that Aristotelianism, and in particular Aristotle's physics, were fully integrated "into the very conceptual fabric of the theoretical discourse of musica mensurabilis." ${ }^{190}$ This integration notwithstanding, Rico still rejects that "Aristotelian concepts ... add anything essential to notational innovations elaborated independently in practice and appear [rather] as ad hoc additions to justify certain theoretical choices."11

In 2008, John Haines and Patricia DeWitt brought the discussion of the influence of Aristotle on late-medieval music treatises to the unique De musica (c. 1275-1300) of

\footnotetext{
${ }^{86}$ Ibid., 6. "I do not pursue further [Max] Haas's investigation of documents associated with the teaching of music in the elementary curriculum or in the medieval faculty of arts." Tanay, Noting Music, Marking Culture, 3.

${ }^{87}$ Rico, "Music in the Arts Faculty," 284. See especially 288-90.

${ }^{88}$ Ibid., 284-87.

${ }^{89}$ Ibid., 291 and 293.

${ }^{90}$ Ibid., 294.

${ }^{91}$ Ibid., 306.
} 
Johannes de Grocheio, which did not introduce any notational innovations. ${ }^{92}$ Whereas this treatise is typically appreciated for its insight into musical practice in Paris near the turn of the fourteenth century, Haines and DeWitt, noting that Grocheio's description sometimes proves problematic, suggest that this approach misses the point of his intention and instead focus on Grocheio as a "philosopher of music."93 His approach to his subject is fully situated within the scholastic tradition, and Aristotle is the primary authority on which he leans. ${ }^{94}$ Haines and DeWitt highlight two Aristotelian methodologies to which Grocheio is "especially indebted." First is Aristotle's procedure for creating order and deriving logical conclusions from first principles. ${ }^{95}$ Second was Aristotle's reliance on observation of the natural world.$^{96}$ A hallmark of De musica is its insistence on the study of music as a sensible phenomenon. It is this standpoint that leads Grocheio to reject the Boethian division of music—musica mundana, musica humana, musica instrumentalis. ${ }^{97}$ Grocheio adopts Aristotle's De animalibus as the template for his own division of music_-popular, mensural, and ecclesiastical—which he based on observation of musical practice in Paris. ${ }^{98}$

\footnotetext{
92 "Grocheio and Aristotelian Natural Philosophy." Although the date given in the literature for Grocheio's De musica is often c. 1300, Constant J. Mews, et al., have recently suggested a date in the 1270s. Grocheio, Ars musice, 10-12. Additionally, this treatise is primarily known in the literature by the name Ars musice. See ibid., 2-3. I have here retained the appellation given in this article.

93 "His aim, made clear in the very first passages of the treatise, was both to incorporate music into a philosophical system on physical reality and to systematize observed music. In this sense, he is best regarded as a philosopher of music, in a different category from either the Neoplatonic tradition stemming from Boethius or the more practical tradition of later medieval music theory whose authors mention philosophy but do not actively contribute to it." Haines and DeWitt, "Grocheio and Aristotelian Natural Philosophy," 48.

${ }^{94}$ Notable is Grocheio's use of a variation on the disputatio format (Ibid., 61-69), which "no other writer on music of Grocheio's time integrated . . into a music treatise to the extent that he does." Ibid., 68.

${ }^{95}$ Ibid., 74.

${ }^{96}$ Ibid., 75.

${ }^{97}$ Ibid., 65-67.

${ }^{98}$ Ibid., 67, 74, 94, and table 4.
} 
Haines and DeWitt, noting the disagreement between Tanay and Page on the importance of Aristotelian thought in late-thirteenth-century music theory, ${ }^{99}$ propose a middle path: "Generally speaking ... it is not so much that Aristotelian naturalism was introduced into music writing as a clever complement, on the one extreme, or that it was the necessary starting point for mensural notation, on the other. It is more that the new Aristotle inspired a variety of fresh perspectives on talking about rhythm in notation." 100 Just as Haines and DeWitt unpack the "fresh perspective" Grocheio derived from his study of Aristotle, an investigation of how Johannes de Muris utilized Aristotelian concepts to understand and explain mensurable music can teach us "much about the breadth and discipline of that 'art or science' of music."101

In 2011, John N. Crossley and Carol Williams presented yet another perspective on Grocheio's Ars musice with implications for the study of the Notitia artis musicae. ${ }^{102}$ They asked what knowledge the Grocheio assumed in his audience. The treatise is addressed to certain young men (iuvenes) to whom Grocheio had likely already provided lectures on the included material. ${ }^{103}$ As outlined by Crossley and Williams, Grocheio expected these young men to be well-versed in the quadrivium (minus geometry), the theoretical and practical music of Paris and its churches, and Pythagorean theory. ${ }^{104}$ Although Crossley

\footnotetext{
${ }^{99}$ Ibid., 70-74. Curiously, Tanay does not address Grocheio's De musica.

${ }^{100}$ Ibid., 71. "By contrast to Franco [of Cologne] and other writers from around this time, Johannes de Grocheio's treatise on music from around 1300 shows a more diligent reading of Aristotle and other authorities, one closer to Tanay's 'total' Aristotelianism." Ibid., 73.

${ }^{101}$ Ibid., 97-98.

102 "Studying Musica in Thirteenth-Century Paris: The Expectations of Johannes de Grocheio."

${ }^{103}$ Ibid., 139. The authors later suggest that Grocheio may have held the position of magister iuvenem, which carried the responsibility "to educate an elite group of monks at the College of Saint-Denis." Ibid., 150.

${ }^{104}$ Ibid., 149.
} 
and Williams were spare in their conclusions, the assessment of authors' intentions and assumptions in addressing a given audience is a welcome and much-needed development in the study of medieval music theory that will be applied in more detail in more detail to the investigation of Muris and his Notitia artis musicae in this paper.

Moving from intentions and assumptions to motivations, Christian Thomas Leitmeir's "Sine Auctoritate Nulla Disciplina Est Perfecta: Medieval Music Theory in Search of Normative Foundations" (2013) sees in the Aristotelian bent of late-medieval music theory a strategy for attaining authority. Calling attention to the "precarious" position of mensural theory given its lack of "any demonstrable precedent in ancient or Patristic times," Leitmeir addresses the issue of auctoritas. ${ }^{105}$ To consider the authoritative base of medieval music theory, he insists that the various aspects of what modern parlance covers under the single term 'music' must be understood. The quadrivial subject musica (musica speculativaltheorica) was a scientia and concerned itself with "facts and circumstances, governed by necessity and not subject to change" and was the study of musical proportions. ${ }^{106}$ Musica practica was divided into ars and usus, the latter referring to the activities of the uninformed practitioner, who was traditionally berated. ${ }^{107}$ Ars, while not a science, does seek out rationally obtained theoretical principles, those related to the practice of music. Unlike scientia, "ars . . deals with artificial objects contingent on their individual producers. . . . [It is therefore unable] to establish principles which can

\footnotetext{
105 Ibid., 39.

106 Ibid., 33-34, quote on 33.

${ }^{107}$ Leitmeir quotes Guido of Arezzo (early eleventh century): "'Nam qui facit quod non sapit, diffinitur bestia' ('For he who does what he does not understand, is defined as beast')." Ibid., 35.
} 
justifiably claim universal validity." 108 The contingent nature of practical music engendered certain challenges in establishing an authoritative foundation, the necessity of which was accentuated by the rapid rate of development of mensural theory from the second half of the thirteenth century. ${ }^{109}$ Further, Leitmeir points out that unlike the mechanical arts, practical music had, since antiquity, carried with it a strong moral component. ${ }^{110}$ From this stemmed the obligation to justify the moral value of any innovations in musical practice.

Much of Leitmeir's article is spent outlining the many creative strategies theorists used to imbue their works with an authoritative aspect. The most prevalent of these strategies was to borrow from other, well-established, disciplines, employing their "paradigms, concepts and argumentative tropes."111 After the middle of the thirteenth century, many practical theorists chose to establish that their theory was in line with the teaching of Aristotle, the preeminent authority. ${ }^{112}$ Theorists even turned to theology for assistance; one included a passage that paralleled the prologue to Aquinas's Summa theologica. ${ }^{113}$ Practical music theory could also appeal to its sister science, musica speculativa. Including preliminary chapters on Boethius's De institutione musica served to imply that the practical theory was built on a solid authoritative foundation. ${ }^{114}$ Leitmeir also suggests that theorists reacted to the 'empirical turn' of the late thirteenth century by supplying musical examples from current repertoire as an appeal to a canonic norm: "The

\footnotetext{
108 Ibid.

109 Ibid., 39, 55-56.

110 Ibid., 36, 40-42.

111 Ibid., 40.

112 Ibid., 40-41.

113 Ibid., 45-46.

114 Ibid., 43-45.
} 
implicit notion of a 'canon' thus helped to sanction contentious theoretical norms." ${ }^{115}$ The most creative (even comical) strategy Leitmeir recounts is the mensural theorist who built his theory around a didactic poem, the presentation of which lent it the illusion of ancient authority despite the fact that it was written by the theorist himself! ${ }^{116}$ Isidore of Seville famously wrote that "without music no discipline can be perfect." ${ }^{117}$ Leitmeir, however, turns this on its head: "Rather than perfecting knowledge and learning, musica (practica) was itself in dire need of normative support."118

Returning to the medieval categories of scientia and ars, Felix Diergarten recounted their Aristotelian significance while analyzing the prologue to Johannes de Muris's Notitia artis musicae in "Omnis ars ex experimentis dependeat: 'Experiments' in FourteenthCentury Musical Thought" (2015). In this article, Diergarten focuses on the concepts of experientia and experimentum - terms, he explains, that were used interchangeably in the Middle Ages ${ }^{119}$ — and how they relate to the formation of principles in an ars or scientia. Muris's prologue is a gloss on Aristotle's introduction to his Metaphysics. Diergarten demonstrates how Muris's gloss explores the interdependence of experimentum and ars. Artists/theorici have propter quid knowledge of universals but the 'merely experienced' practici/experti only have a quia knowledge of particulars. Here Muris takes a stand in the medieval discussion of universals: "because universals presuppose particulars, ars presupposes experientam."120 Although Muris retains the supremacy of the theorist over the

115 Ibid., 51-54, quote at 52.

116 Ibid., 46.

117 "Itaque sine musica nulla disciplina potest esse perfecta." Quoted in Ibid., 31.

118 Ibid., 60. Leitmeir suggests this emendation: "Sine auctoritate musica non est perfecta."

119 Diergarten, "'Experiments' in Fourteenth-Century Musical Thought," 46.

${ }^{120}$ Ibid., 50. 
practitioner, ${ }^{121}$ he acknowledges the necessity of experience in the development of universals. Diergarten explains that "Muris's epistemology—that is, Aristotle's epistemology—is more complex than a simple one-way street ascending from sensation and experiment to general knowledge. Rather, it describes experience and theory, knowledge of particulars and knowledge of universals, in a dialectic entanglement, in a hermeneutic circle."122 This 'hermeneutic circle' can then be seen as an organizing principle in Muris's Notitia, where he was responding to contemporary changes in musical practice with informed theoretical solutions. ${ }^{123}$

As we have seen, recent musicological research into the intellectual contexts and foundations of late-medieval music theory have moved beyond questions of its connections with the arts curriculum and faculty at Paris. Karen Desmond's new book, Music and the moderni, 1300-1350: The ars nova in Theory and Practice, seeks to put the developments in French polyphonic music of the first half of the fourteenth century in not just an intellectual, but also a cultural, context. Indeed, almost in passing, she establishes the connection between the ars nova innovations and the arts faculty in one primary source quote in her introduction. ${ }^{124}$ Desmond's "students and/or masters of the university's Faculty of Arts" do not, however, exist in a hermetically sealed, scholarly world. Johannes de Muris, a figure who stands out prominently in this work, is given a certain three-

\footnotetext{
121 "Therefore we assume that artists are wiser than the [merely] experienced." Quoted in Ibid., 49.

${ }^{122}$ Ibid., 51.

${ }^{123}$ Ibid., $52-56$.

${ }^{124}$ The quote is from the Cantuagium (1380) of Heinrich Eger von Kalkar (1328-1408), who studied and taught in Paris during his middle years: "Around the year 1330, certain great students [and/or masters] of the arts in Paris ... specifically dedicated themselves to the exact measurements of music's tempora," Desmond, Music and the moderni, 5-6. Desmond also includes a short discussion, based on Gilles Rico's dissertation, of the place of music, speculative and practical, in the arts curriculum as well as the connection of some of the leading mensural theorists to the university. Ibid., 9.
} 
dimensionality. As Desmond notes, Muris's musico-theoretical and astronomical works tend to be addressed exclusively in the literature of their relative disciplines. Admitting that "a single chapter cannot hope to address this gap in knowledge," she adopts "a synthetic approach," which seeks to assess the various sides of Muris's intellectual career and "interrogate [his] articulation of his general scientific purpose."125 This interrogation includes speculation concerning Muris's courtly contacts based on scanty yet enticing references in his own writing, which place him in the company of the Queen of Navarre, among others. ${ }^{126}$ Desmond's primary cultural contextualization places the ars nova innovations in a culture that prized and sought after subtilitas. ${ }^{127}$ She explores the "multivalent resonances of the term" in classical and medieval texts, both musical and nonmusical, and traces those resonances in the "aesthetic . . of the 'new art of music."'128 Music and the moderni is wide-reaching and multifaceted. It is at once able to engage with trends in scholastic thought, ${ }^{129}$ analyze musical compositions, ${ }^{130}$ and seek contextualization in the broader culture. It introduces an exciting new phase in musicological writing, one that has long been called for.

As scholars have struggled to outline and define the intellectual context of latemedieval music theory, certain questions have been satisfactorily answered, leaving room for a more penetrating analysis. It has been well established that the first two books of Boethius's De institutione musica were taught at the University of Paris throughout the

\footnotetext{
${ }^{125}$ Ibid., 75 and 76. See Chapter 3, "Jean de Murs, Quadrivial Scientist," 70-114.

${ }^{126}$ Ibid., 70-73.

${ }^{127}$ See Chapter 2, "Subtilitas and the ars nova," 35-69.

${ }^{128}$ Ibid., 36.

${ }^{129}$ See "'The unity of form' versus 'the plurality of forms,"' 162-66, and Desmond's assessment of the influence of these concepts on music theory, 166-83.

${ }^{130}$ See Chapter 6, "Notational Dots and the Line of Musical Time," 198-236.
} 
thirteenth and fourteenth centuries, though only cursorily after the rise in prominence of Aristotle's natural philosophy. Likewise, it is clear that the intellectual trends which occupied the arts faculty found their way into contemporary music theory. More contingently, it is probable that the prominent developments in that theory were introduced by men who had studied in that institution. Nevertheless, that simple correlation misses the subtlety of the complex set of interactions that obtained between c. 1250 and c. 1350 . Ideas engendered in the intellectual climate of the arts faculty were not doomed to stay within the confines of the Rue du Fouarre but rather were fostered wherever interested parties dwelled, be it abbey or college. ${ }^{131}$ Their appearance in the treatises notwithstanding, the extent to which various school-born ideas shaped or informed the actual content of music theory and the sound of the music produced is far from settled. John Haines and Patricia DeWitt's assessment that "the new Aristotle inspired a variety of fresh perspectives on talking about rhythm in notation" is sober-minded and almost certainly a move in the right direction. ${ }^{132}$ As Felix Diergarten observed, experience and theory function together in a 'hermeneutic circle.' Likewise, the historian's awareness of the multi-directional relationship between theory and practice will lead to insights into the impact of scholasticism on music. Karen Desmond has advanced this discussion considerably in her Music and the moderni, in which she traces scholarly debate to music theory to composition. It reminds us that a close study of the myriad pressures, influences, and expectations on individual historical actors can aid us in revealing the nuances of broad and complex historical changes.

\footnotetext{
${ }^{131}$ See Jeffreys, "Exchange of Ideas About Music." See n. 83, above.

${ }^{132}$ Haines and DeWitt, "Grocheio and Aristotelian Natural Philosophy," 71.
} 
The scholarship reviewed in this chapter has greatly illuminated our understanding of the interaction between the curricular concerns of the medieval university and literate efforts to make sense of and record a dynamic soundscape. The focus of this scholarship has primarily been on those interactions, the ideas and their movement as found in those efforts. This thesis takes a different perspective, shifting the focus to one historical actor, Johannes de Muris, who, in the course of his life, responded to the needs of an art in the throes of expansion. It situates his first response to those musical needs in the context of his life, education, academic interests, and career. It is from the perspective of Muris himself that I investigate the ideas and their movement. Some of the scholars discussed above have made contributions that focused on the authors of texts. John N. Crossley and Carol Williams asked about Grocheio's intentions and assumptions in writing his Ars musice. Karen Desmond has done much to incorporate Muris's astronomical activities into a broader understanding of his scholarly methods. Indeed, Music and the moderni is a magisterial work, and it is my hope with this thesis to make a modest contribution to her portrait of our quadrivial scholar. My research, however, has asked different questions than hers. Whereas Desmond's investigation sought to illuminate shifts in musical taste and thinking, clarifying the scope and timeline of the ars nova, and it is toward this end that she applied her more comprehensive study of Muris, my research has asked how Muris understood the musical issues of his day, what he brought to bear on them, and why. In pursuit of answers to these questions, I have drawn extensively on the works cited in this chapter, particularly those by Gilles Rico, Dorit Tanay, and Karen Desmond. Although I have had cause to disagree with some of their conclusions, their scholarship has 
formed the foundation on which this thesis stands. Further, Felix Diergarten's analysis of the "prologue" of the Notitia artis musicae was profoundly influential on my own, and my approach to the remainder of the treatise was in many respects an extension of his insights. Finally, Christian Thomas Leitmeir's conclusion that mensural theory was in need of an authoritative foundation informed my own conclusions about Muris's intentions.

Although much of what this thesis contributes to the scholarship is its synthesis from a unique perspective, certain untrodden avenues of inquiry required exploration. Despite the extensive study the Notitia artis musicae has received, its first book has been all but ignored. Lawrence Gushee and C. Matthew Balensuela passed it over in a single sentence: "Book 1 would appear to fill some kind of conventional requirement, while book 2 represents, so to speak, the real meat of a master's thesis."133 Additionally, Jan Herlinger provides a one-page summary. ${ }^{134}$ Diergarten's chapter on the Notitia's "prologue" stands as the only sustained analysis of a portion of the contents of Book I. This thesis fills that lacuna by providing a detailed analysis of Book I of the Notitia, Musica theorica, seeing it as an indispensable part of a whole and critical to an understanding of Muris's treatise. This analysis flowed from my work in translating Book I from the Latin—although Book II, Musica practica, was published in English translation in 1950, ${ }^{135}$ Book I never has beenand the results of that labor are included in an appendix.

\footnotetext{
133 Gushee and Balensuela, "Muris, Johannes de," 411.

134 Herlinger, "Music Theory," 295-96.

${ }^{135}$ McKinnon, Strunk's Source Readings [Originally published as Source Readings in Music History, selected and annotated by Oliver Strunk]. This translation also includes the introduction and conclusion of the Conclusions, which Desmond convincingly argues are an independent work or a somewhat later addition to the Notitia. Desmond, Music and the moderni, 28-31.
} 
This thesis also brings to light concrete connections between Muris's knowledge of astronomy, its sources and methods, and the formulation of his mensural theory. In addition to recognizing Ptolemaic influences on Muris's ontology and epistemology, influences that helped shape his approach to the Notitia, this thesis will demonstrate Muris's adoption of astronomical organizational methods into the function of his music theory.

The main advantage that I see to the approach taken in this thesis is its inclusivity. The perspective presented here provides a framework for understanding Muris and his mensural theory. As such, it is not a closed system; rather, it allows room for other interpretations and foci. It is also my hope that positioning Johannes de Muris in a broader cultural context invites an interest in his work to historians of all stripes. 


\title{
Chapter Three
}

\author{
Johannes de Muris: The Early Years
}

We will begin our story with the known details of the early life of Johannes de Muris. Although scarce, they provide us with a time, place, and milieu, sufficient information from which to construct a detailed, if generic, account of his experience. We can take his own word for it that Muris was born in the diocese of Lisieux. In his Expositio intentionis Regis Alfonsii (1321), Muris refers to himself as "de Normannia oriundus in episcopatu Lexoviensi." 136 Whether he was from the city of Lisieux or some other town is not known. Bernay has been suggested, but as it is far from conclusive, I will not explore its possibility here. ${ }^{137}$ Likewise, the year of his birth is not known, though 1295 seems to be an accepted guess. ${ }^{138}$ Hereafter, I will be using that date in this paper, for the sake of convenience and consistency, but it should be understood to be an estimation. When we first hear from Muris, he is observing a lunar eclipse in Paris in 1312. ${ }^{139}$ From the Expositio, we also learn that in 1319, Muris was a student in the arts faculty. ${ }^{140}$ We can assume, then, that between 1312 and 1319, Muris lived in Paris where

\footnotetext{
${ }^{136}$ Poulle, "Les tables Alphonsines," 265. The full passage reads: "Noverint preterae universi presentes et futuri quod ego, Johannes de Muris, pro tempore degens Ebroici, studens in facultate artium, de Normannia oriundus in episcopatu Lexoviensi, una vice considerans circa motus planetarum, introitum solis in arietem volui reperire anno Domini 1318." Emmanuel Poulle has convincingly argued that the year should be considered perfecto, i.e. 1319. Ibid., 266. This passage also appears, with variants in the transcription, in Gushee, "New Sources," 6. For the Expositio, see n. 323, below.

${ }^{137}$ Gushee, "Murs and his Milieu," 347-48.

${ }^{138}$ Ibid., 346-47.

${ }^{139}$ Ibid., 346. This comes from a note on a calendar next to the date Dec. 14 (Escorial, Real Biblioteca de San Lorenzo, MS O.II.10, fol.10r). There was, according to NASA, a penumbral eclipse on Dec. 15, 1312. https://eclipse.gsfc.nasa.gov/LEsaros/LEsaros004.html (seq. no. 68).

${ }^{140}$ See n. 136. In 1321, Muris was referred to as magister, indicating that he had graduated with his master's degree from the faculty of arts sometime between 1319 and 1321. Gushee, "New Sources," 6-7.
} 
he was a student at the university. In March of 1319, Muris observed a vernal equinox in Évreux, where he was living "pro tempore," suggesting his time in Paris was not uninterrupted. ${ }^{141}$ It was in this year that Muris wrote his Notitia artis musicae. ${ }^{142}$

Normandy and Lisieux

Writing in the middle of the fifteenth century, Robert Blondel described his homeland of Normandy this way:

Normandy was formerly called Neustria because of its natural fertility. Today it takes its name, properly speaking, from the Normans who, sailing from Norway and fighting under Duke Rollo, gained by their feats of arms the coast lands of the Gallic sea and finally ended up in possession of the whole province to its furthest boundaries .... It is bounded by the Breton ocean to the west, France to the south and the sea to the north. It is a land which is very fertile, with luxuriant and abundant pasture for sheep, and fruitful forests and meadows filled with a variety of wild animals and birds. It is rich in rivers and sea ports, filled to overflowing with fruit-bearing trees, endowed with notable towns and provided with many strongholds. Its metropolitan see is Rouen, a mighty town by virtue of its ancient population and its wealth, situated on the river which is called Seine. ${ }^{143}$

Though written a century and a half after our period, this description is telling in a few ways. First, part of the pride of homeland comes from its history. And that is a history of conquering, starting with its founding. Second, the boundaries of Normandy are very clear. It is a characteristic of Normandy that its borders were well-defined and consistent. ${ }^{144}$ Third, we get a beautiful depiction of Normandy's topography: lovely, gently rolling pastures bordered by forests and cut through by lazy rivers. Indeed, fruit

\footnotetext{
${ }^{141}$ See n. 136. For this observation, see pp. 76-79.

142 "The earliest extant manuscript copy of Notitia (BnF lat. 7378A) contains an explicit with a date of 1319 on fol. 60v." Desmond, Music and the moderni, 28. No other manuscript copy includes a date.

${ }^{143}$ Quoted in Contamine, "The Norman 'Nation,"' 219.

${ }^{144}$ Ibid., 218.
} 
trees and mixed husbandry were two of its main natural resources. ${ }^{145}$ Lastly, it is notable that though Normandy was annexed to France in 1204, some 250 years later there is still a fervent national spirit.

Normandy was an expansion powerhouse in the eleventh and twelfth centuries. A Norman famously took the English crown in 1066, and in 1091, another conquered Sicily. But this all came to an end. Normandy was annexed to the French crown in 1204 , and the Sicilian territories finally slipped from Norman control in $1268 .{ }^{146}$ As we saw earlier, however, the Normans remained self-confident and proud of their heritage. And when King Philip II Augustus (1180-1223) acquired Normandy, he added a wellorganized land to his realm. It had, in fact, a better-run financial system than France. ${ }^{147}$ Consequently, Philip retained the administrative mechanisms of Normandy, only making small adjustments. After 1204, many local and regional administrative and judicial positions were filled by men from the old domain of France. ${ }^{148}$ Although this was still the case for the majority of bureaucratic personnel under Philip the Fair (1268-1314), the number of Normans increased substantially and far outweighed any other group from a newly acquired territory. ${ }^{149}$

\footnotetext{
145 Jordan, The Great Famine, 120.

146 Neveux, "La constitution," 193.

${ }^{147}$ Strayer, Reign of Philip the Fair, 146.

148 Ibid., 42.

149 Ibid., 42-43.
} 


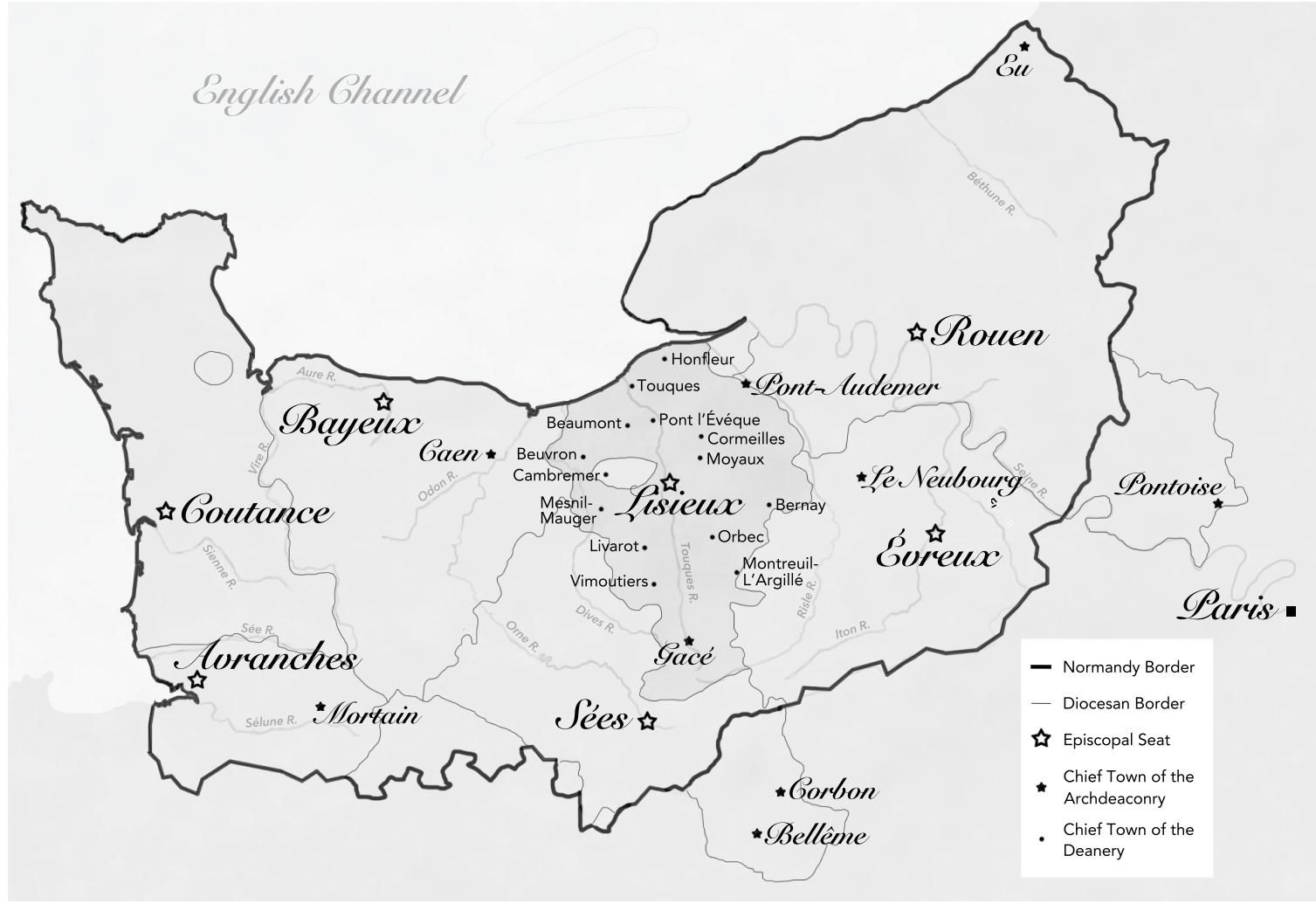

Figure 1 Normandy and the diocese of Lisieux (map: Jen Raynak)

The interior of Normandy has a temperate climate with typically mild winters and warm summers. And much like the Oregon coast, it rains year-round, not a lot, but frequently. Modern Lisieux has average temperatures of $62.2^{\circ} \mathrm{F}$. in the summer and $40^{\circ} \mathrm{F}$. in the winter. Reconstructing ancient weather statistics is notoriously difficult, and making sense of this research is nearly as hard. Nevertheless, it seems that Europe was going through a warm period during the years between 1250 and 1350 with substantial interruptions starting in the year $1310 .{ }^{150}$ Considering modern rising global temperatures, average temperatures during Muris's childhood would still have been slightly less than

${ }^{150}$ Brown, History and Climate Change, 224. 
they are today. ${ }^{151}$ Given all this, and taking into account the imprecision of the data, it can be assumed that the climate of Lisieux during the first fifteen years of Muris's life was essentially the same as it is today, if slightly cooler. ${ }^{152}$

The diocese of Lisieux was centrally located in Lower Normandy and encompassed the archdeaconries of Auge, Lieuvin (roughly equivalent to today's Pays d'Auge and Lieuvin regions), Gacé, and Pont-Audemer. Each archdeaconry was subdivided into deaconries, each of which had its seat in the largest town. ${ }^{153}$ The episcopal city of Lisieux sat right on the Touques river about a third of the way down the diocese from the English Channel (see Fig. 1). Administratively, the city was something of a special case. In 1199, King John had granted the bishop of Lisieux temporal lordship, which was then extended by Philip Augustus in $1204 .{ }^{154}$ This, however, only pertained to the city itself and its immediate suburbs. The population of Lisieux has been estimated at around three to four thousand for the fourteenth and fifteenth centuries, ${ }^{155}$ so at Europe's peak population ca. 1300, we might expect to find some five thousand souls in Lisieux. We can compare this to Rouen, the urban center of Normandy, which had a thirteenthcentury population of approximately thirty to forty thousand. ${ }^{156}$ As the seat of the bishopric, Lisieux had a cathedral. It is an indication that the bishops of Lisieux already

\footnotetext{
${ }^{151}$ Diaz, et al., "Climate in Medieval Times," 1490.

${ }^{152}$ Specific and substantial anomalies will be addressed below.

${ }^{153}$ These towns were, moving north to south: Honfleur (on the English Channel), Touques (on the Touques River), Pont-l'Évêque (also on the Touque River), Beaumont, Cormeilles, Beuvron, Moyaux, Bernay, Mesnil-Mauger, Orbec, Livarot, Montreuil-L'Argill, and Vimoutiers. Next larger were Gacé in the south and Pont-Audemer in the northeast, seats of the archdeaconry of Lieuvin and Auge, respectively (see Fig. $1)$.

${ }^{154}$ Neveux, "La constitution," 925.

155 Ibid., ๆ 36.

${ }^{156}$ Ibid.
} 
had an eye for Paris in the twelfth century that its cathedral shows little influence from Norman architecture and belongs more properly to the Parisian French tradition. ${ }^{157}$ Though at its construction certain features were already outdated by the standards of Northern French cathedrals, it shared many architectural features, including thin walls and flying buttresses. ${ }^{158}$ By the mid-thirteenth century, the chapter maintained thirty-one canons with full prebends. ${ }^{159}$ On the whole, these were men who had studied in Paris and were a part of the cosmopolitan intellectual community. ${ }^{160}$ In the mid-twelfth century, Arnulf, bishop of Lisieux (r. 1141-1181), was outspoken about the intellectual and cultural preeminence of his household vis-à-vis others in the region. ${ }^{161}$ Though the assumption is unsubstantiated, it is possible that these Paris-educated canons maintained the heritage of intellectual distinction at the cathedral. In any respect, the chapter was sufficiently large to warrant a cathedral school, and it might have been here that Muris received his education in Latin grammar and the trivium. Additionally, he may have learned to sing chant in the cathedral choir and perhaps even read a bit of Boethius's De institutione musica. Indeed, Muris's early musical and mathematical educations could have been one and the same. ${ }^{162}$ Again, the best we can do is speculate. Lisieux cathedral was also likely the place where Muris first heard the awesome sounds of Parisian

\footnotetext{
157 Grant, Architecture and Society in Normandy, 85.

158 Ibid., 88.

159 Ibid., 20.

${ }^{160}$ Ibid., 27.

161 Ibid., 28.

${ }^{162}$ De institutione musica dealt with music as a mathematical subject. See p. 62-64, below. It was a difficult work and would only have been tackled by a precocious young student. There is reason to believe Muris fit this description.
} 
organum and discant. ${ }^{163}$ Senior clergy educated in Paris were the main avenue for the dissemination of new musical trends, and they may have brought back popular forms for their own, and possibly interested students', amusement and edification.

Muris was also sure to have encountered - and, indeed participated in makingmusic in his home town, and certainly in Lisieux. In his Ars musice, an account of the musical life of Paris ca. 1275, ${ }^{164}$ Johannes de Grocheio, himself a Norman (or so it has been argued), ${ }^{165}$ referred to a form of music sung by girls and young men in Normandy: "But any round or rotundellus is called a cantilena by many in that it turns back on itself like a circle and begins and is terminated at the same place. ... And a cantilena of this type is usually sung in the west, namely in Normandy, by girls and young men at feasts and at great celebrations for their enhancement." ${ }^{166}$ Grocheio mentions another kind of cantilena, the ductia, "which is sung in caroles by young men and girls." ${ }^{167}$ Though maligned from the pulpit, the carole, or round dance, was a popular group amusement throughout northern France during the High Middle Ages in both rural and urban areas. ${ }^{168}$ On major feast days, Muris would have seen the local girls decked out in their finest, holding hands, and dancing in a circle. Also, he would have heard the music that

\footnotetext{
${ }^{163}$ Organum is a hypnotic polyphonic embellishment of a chant whereby its syllables were drawn out into long, extended notes and accompanied by a newly-composed, melismatic line. Discant is a faster-moving, note-against-note polyphony, also a chant embellishment. By the end of the thirteenth century, these forms had become old-fashioned in Paris but were still widely loved.

${ }^{164}$ For the dating of the Ars musice, see Grocheio, Ars musice, 12.

${ }^{165}$ Ibid., 3-4.

166 "Cantilena vero quelibet rotunda vel rotundellus a pluribus dicitur eo quod ad modum circuli in seipsam reflectitur et incipit et terminatur in eodem. Nos autem solum illam rotundam vel rotundellum dicimus cuius partes non habent diversum cantum a cantu responsorii. Vel refractus et longo tractu cantatur velud cantus coronatus. Cuiusmodi est gallice. Toute sole passerai levert boscage. Et huiusmodi cantilena versus occidentem puta in normannia solet decantari a puellis et iuvenibus in festis et magnis conviviis ad eorum decorationem." Text and translation in ibid., 69.

${ }^{167}$ Ibid.

${ }^{168}$ For round dances, see Salmen, "Dances and Dance Music," 173-77.
} 
accompanied them, possibly a ductia. Minstrels were often employed to perform this service on wind instruments; the girls themselves would often play a drum and sing. ${ }^{169}$

He would not have known it at the time, but Muris had been born during a liminal state in Europe's history, when it was just starting to feel the first tremors of what would erupt into full economic, climatic, demographic, and eventually epidemic crisis. ${ }^{170} \mathrm{By}$ 1295, Europe had reached its population zenith and plateaued. The economy had been largely monetized, even in rural areas. Aside from Rouen and Caen, the two major cities, and a handful of medium-sized cities (of which Lisieux was one), Normandy was, indeed, largely rural, despite a general trend toward urbanization. By the end of the twelfth century, and increasingly over the thirteenth, even these rural populations were able to participate in an interconnected trade economy. ${ }^{171}$ This left Normandy, like most of Western Europe, vulnerable to the vagaries of the market economy. This economy would soon be thrown into turmoil by the Dantean anomaly—which was foreshadowed by bad winters starting in $1305^{172}$ —and the Great Famine. Significantly, the first ten or so years of Muris's life were a time of great monetary instability. ${ }^{173}$ Philip the Fair repeatedly debased and overvalued the coinage between the years 1296 and $1303 .{ }^{174}$ Muris's earliest conception of money would have be bound up with memories of the king's representative informing his town of the new coinage. Every time the coin was debased, all old coins

\footnotetext{
${ }^{169}$ Page, Owl and the Nightingale, 114 and 118. Page speculates that the songs used for caroles may have influenced the development of the motet, which we will meet later (see pp. 65-75).

${ }^{170}$ Harvey, "Introduction: The 'Crisis,"' 1.

171 Jordan, The Great Famine, 46 and 43. Jordan, however, warns that we should not overestimate these trends (48).

172 Brown, History and Climate Change, 250.

173 Joel Kaye cites the years 1295-1305, 1326-29, 1337-43, and 1346-60 as "the four periods of most extreme monetary instability." Economy and Nature, 20 n. 24.

${ }^{174}$ Strayer, Philip the Fair, 152.
} 
had to be exchanged for new ones at the official exchange rate. ${ }^{175}$ If Muris were aware of these transactions, perhaps he showed an interest in the calculations they required. Seven or eight years old is not too young to start learning basic math (or younger, if the child is precocious), and an image of math lessons using exchange rate calculations is tempting but must remain in the bounds of speculation. In any case, he grew up in a time when Europe's economic and monetary advancements (as well as its fiscal instability) resulted in fairly widespread, everyday numeracy. ${ }^{176}$ Much later in his life, Muris himself made the connection between commerce and mathematics in his Quadripartitum opus numerorum (1343): "By this method, you will now be able with little outlay to settle all accounts with changers and other people in an advantageous way."177

\footnotetext{
175 Kaye, Economy and Nature, 21.

${ }^{176}$ Joel Kaye points to the "habits of thought" that followed from Europe's rapid monetization between 1180 and 1320: "the focus on monetary profit and loss in a wide range of decision making; the recognition of the importance of detailed written records for this calculation; the resulting broad development of literacy and numeracy; and the translation of qualitative values into quantitative, often monetary, terms as a way to simplify the process of calculation" (my emphasis). Economy and Nature, 16. Alexander Murray identifies commerce and merchants' accounting as "the main source of European arithmetic." Reason and Society, 189-94.

${ }^{177}$ Quoted in ibid., 190.
} 


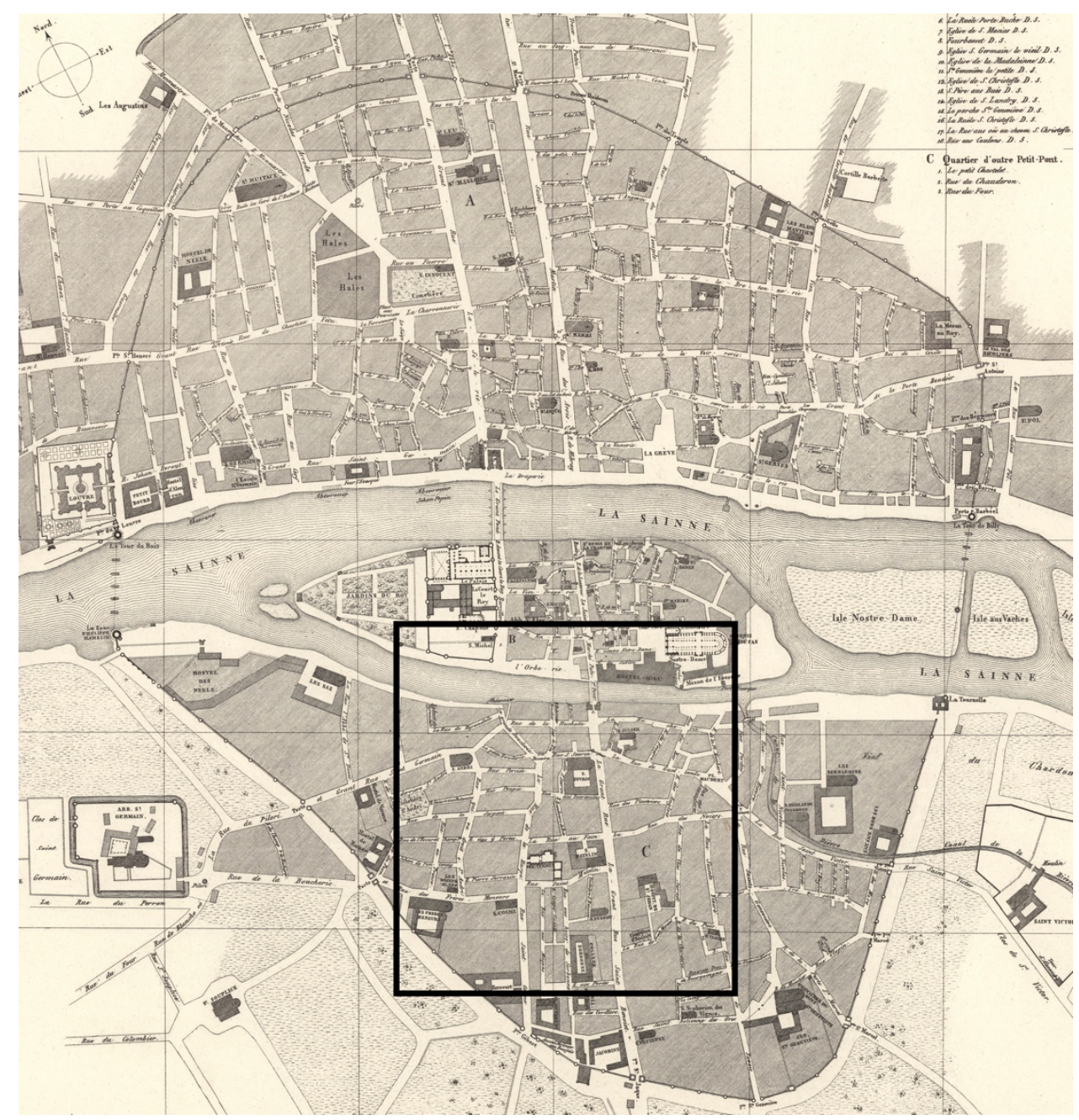

Figure 2.1 Early fourteenth-century Paris (Albert Lenoir / David Rumsey Historical Map Collection / Public Domain, slightly modified) Insert: Latin Quarter (see p. 52)

\section{$\underline{\text { Paris }}$}

In 1312, Muris packed up and moved to Paris. ${ }^{178}$ Lisieux is 105 miles from Paris, and on foot, the trip would have taken about four and a half days under normal conditions (three by horse). ${ }^{179}$ Muris, at least in theory, would have been aided in his journey by the

\footnotetext{
${ }^{178}$ Muris may have moved to Paris before 1312, we only know that he was there by then.

179 "William Boner, a chaplain from Kirklington in York diocese . . . thought the more ordinary travellers [sic] might cover thirty [miles in a day]." Harvey, "Travel from Durham to York," 122. Hilde de Ridder-
} 
goodwill of Philip IV, who expanded and sought to enforce earlier papal charters that exempted students traveling to Paris from the usual payment of tolls and duties and forbade their molestation. ${ }^{180}$ Unfortunately for many students, these injunctions were often ignored. Arriving from the west, Muris would probably have skirted the Seine and entered the city through one of the four gates on the Southwest side (Porte St. Germain, Porte St. Michel, Porte St. Jacques, or Porte Ste. Geneviève), entering directly into the Latin Quarter. Alternatively, he could have traveled east from Lisieux to the Seine and ridden a barge to Paris, disembarking into the Latin Quarter. In either case, the experience must have been intense and visceral. If he came through the southernmost of the gates, he would have almost immediately smelled the foul odor of the slaughterhouses on the Rue Ste. Geneviève, where the animal waste was thrown into the streets. ${ }^{181}$ If he hopped off a barge in the shadow of the cathedral, he would have been thrown into a world of prostitutes, fishermen, and dock workers. ${ }^{182}$ The Latin Quarter was a bustling and motley neighborhood. The university population alone was nearly ten thousand people (including clergy, students, and masters), twice that of Lisieux. ${ }^{183}$ Living and working among them was a wide variety of shopkeepers, merchants, and artisans, including carpenters, jugleors, locksmiths, parchment-makers, porters, prostitutes,

Symoens estimates that "travellers on foot could do 30 to $40 \mathrm{~km}$ (20 to 25 miles) a day and horsemen 50 to $60 \mathrm{~km}$ (30 to 40 miles) a day." "Mobility," 300.

${ }^{180}$ Kibre, Scholarly Privileges, 100 and 136.

${ }^{181}$ Ibid., 153. This issue came to a head after mid-century when masters of the university issued a formal complaint to King John. Ibid., 153-54.

${ }^{182}$ Geremek, Margins of Society, 89 and 76.

${ }^{183}$ Ibid., 75. William Courtenay points out the inconsistencies in estimates of the population of the University of Paris, citing examples between five thousand and an unlikely twenty thousand. Parisian Scholars, 19-20. Lawrence Gushee also suggests a university population of near ten thousand. "Two Central Places," 137. 
second-hand clothes dealers, shoemakers, tailors, and wood merchants. ${ }^{184}$ The Latin Quarter boasted ten churches, ten monasteries and convents, student residences, colleges, ${ }^{185}$ many inns, and nearly 60 or so student taverns. ${ }^{186}$ In addition to the clamor of city life, Muris may have felt the tension of scarcity. Paris was experiencing a dearth of grain as early as 1306, and nothing the crown did could keep grain prices from escalating astronomically. ${ }^{187}$

Muris's first order of business would have been to secure some sort of temporary lodging. The next critical step would be to find a master under whom to study. This man would have almost certainly been a Norman well-versed in mathematics and astronomy. ${ }^{188}$ It is possible that he had already received a recommendation from one of the canons of Lisieux. Otherwise, he would have "shopped around" until he found someone he liked. In either case, this was an important step, as the student-master relationship was a long-term one. Finding a master often meant that lodging was also secured. It was not uncommon for a master who owned or held the lease to a property to live with and rent out rooms to students, often his own. ${ }^{189}$ This was not only mutually beneficial financially speaking, but it also provided the opportunity for additional instruction. Depending on Muris's means, he would have either lived with other students, paying rent

\footnotetext{
${ }^{184}$ Geremek, Margins of Society, 76 and 189; Gushee, Two Central Places, 138.

185 Courtenay, Parisian Scholars, 60.

${ }^{186}$ Overman, "Student in the Medieval University," 292. Bronisław Geremek claims there were 100. Margins of Society, 75.

187 Jordan, The Great Famine, 173 and 135.

${ }^{188}$ Courtenay, Parisian Scholars, 87. José Chabás and Bernard Goldstein suggest that the dedicatee of a short astronomical treatise from 1321 by Muris was John Vimond, a Norman astronomer and teacher in the arts faculty. "John of Murs Revisited," 412. C. Philipp Nothaft subsequently posited that this dedicatee, perhaps Vimond, may have been Muris's teacher. "A Problem of Authorship," 210. For Vimond, see Chabás and Goldstein, "Tables of John Vimond."

189 Courtenay, Parisian Scholars, 86-88.
} 
to the usually live-in lease holder, who was potentially also his master, or, like some wealthy and senior students, held his own lease. ${ }^{190}$ Although they could be found in all parts of the Latin Quarter, arts masters and students often took residences in the vicinity of the school of arts on the Rue du Fouarre, not far from the Seine. This area boasted many taverns and was a popular site for students to get together and look for a little fun. ${ }^{191}$

\section{The Dantean anomaly and Great Famine}

In 1314, after Muris would have advanced to a bachelor, it started raining in earnest. And the next year, it only got worse. ${ }^{192}$ Contemporary reports tell of near-continuous downpours. ${ }^{193}$ The scholarship on the weather conditions during this time varies in the details of its timeline, but there is general agreement: during the early fourteenth century, continental Europe was experiencing not only some of the wettest years of the medieval period, but also some of the coldest winters. ${ }^{194}$ Neville Brown reports that the rain that started in the summer of 1314 kept up near ceaselessly from 1315 until 1317. ${ }^{195}$ William Chester Jordan cites a study that puts the years $1310-1320$ as "the second worst period for severe, sustained summer downpours for the Middle Ages as a whole."196 As for severe winters, Brown identifies the winters of $1305 / 06,1317 / 18$, and 1322/23 as standouts for their bitterness and longevity while noting that "on mainland Europe, no winter was mild, by twentieth-century

\footnotetext{
${ }^{190}$ Ibid., 82-84.

${ }^{191}$ Geremek, The Margins of Society, 150.

${ }^{192}$ Brown, History and Climate Change, 252.

${ }^{193}$ Lucas, "The Great European Famine," 346-48.

${ }^{194}$ Neville Brown coined the term "Dantean anomaly" to refer to this "bad weather crisis of 1314-22." The name is a reference to Dante's death in 1321. History and Climate Change, 251.

${ }^{195}$ Ibid., 252.

${ }^{196}$ Jordan, The Great Famine, 17.
} 
standards, between 1305 and 1328."197 Again, Jordan's reported dates start a little later but express the same severity in roughly the same time period: "for sheer length of time the succession of miserably cold winters in the years 1310-1330 was incomparable."198

The results of these bad winters were disastrous. Across Europe there was severe flooding, and fields were left devastated. Much marginal land with thin top-soil and bad drainage was put out of cultivation for years to come. ${ }^{199}$ Combined with the harsh winters, this truly awful weather played havoc on agricultural yields, and 1315 saw Europe plunged into the Great Famine. It is difficult to overestimate the severity of this near-Europe-wide catastrophe. Famine was almost immediately accompanied by disease. ${ }^{200}$ The majority of the reported widespread mortality was a result of these diseases that attacked a malnourished and weakened population. ${ }^{201}$ Scarcity was followed by wild price inflation. It has been estimated that the price of grain in France rose by up to eight hundred percent between 1315 and 1318. ${ }^{202}$ Salt production was also severely undermined by these years of continually overcast (to put it mildly) conditions. ${ }^{203}$ This situation persisted for seven long years, only subsiding after Muris had his master's and had started teaching. Like most urban centers, Paris was hit hard by the effects of the famine.

\footnotetext{
${ }^{197}$ Brown, History and Climate Change, 250 and 252. As a testament to the confusion in sorting out these dates, even as reported by one author, of the winters of 1305/06 and 1322/23 Brown says "the duration and intensity of the cold could match the worst these last 300 years (i.e. 1788/89 and 1962/63)" (250), but then goes on to report that the winter of 1317 "proved the harshest of all: four or five months of numbing cold" (252).

${ }^{198}$ Jordan, The Great Famine, 17.

${ }^{199}$ Ibid., 25.

${ }^{200}$ Lucas, "The Great European Famine," 357.

${ }^{201}$ Jordan, The Great Famine, 116-17.

202 Ibid., 50.

${ }^{203}$ Though contemporary records do not exist for specific increases, France, like England, saw steep rises in salt prices, perhaps more than double what they were a decade before. Ibid., 53-54. This figure obtains in extant records for England.
} 


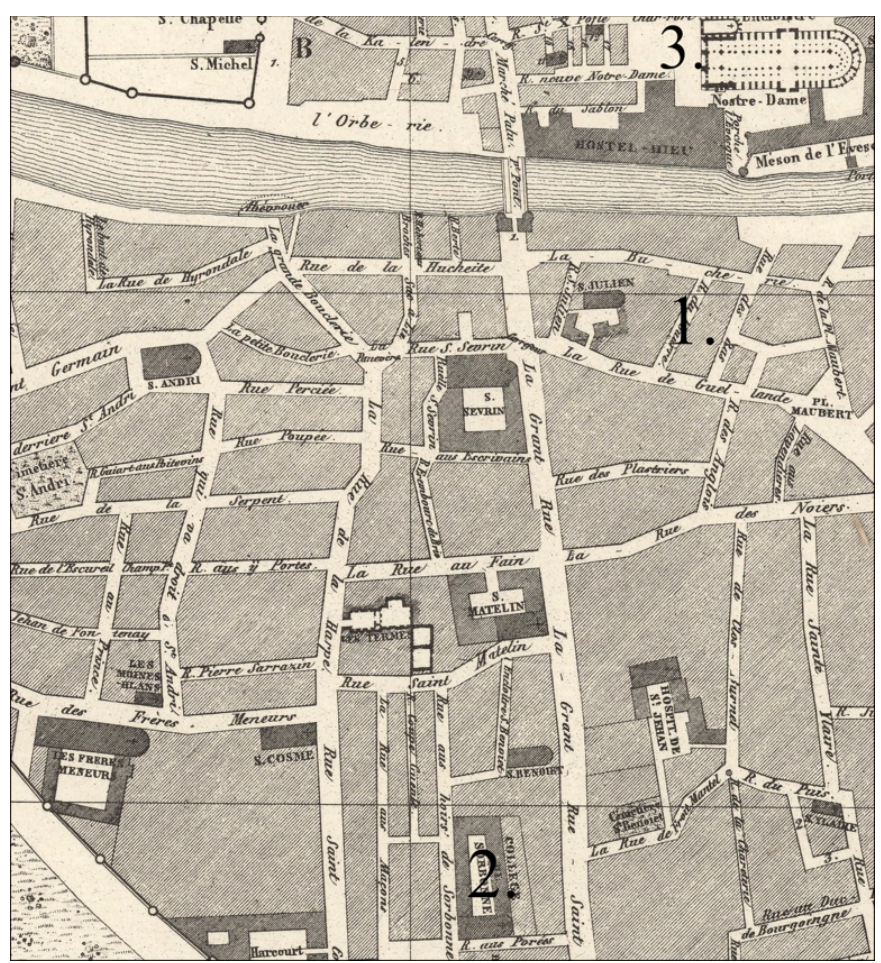

Figure 2.2 Latin Quarter of Paris (Albert Lenoir / David Rumsey Historical Map Collection / Public Domain) 1. Rue du Fouarre/school of arts 2. Sorbonne 3. Notre-Dame cathedral

\section{$\underline{\text { Parisian student life during rough times }}$}

Under normal conditions, winter life in Paris was a cold one for students. Houses were drafty and usually only heated by a central fireplace. ${ }^{204}$ Bedrooms collected whatever heat they could from little coal burners. ${ }^{205}$ But Muris did not spend his time in Paris under normal conditions. One can imagine Muris, the gifted student, turning the pages of a manuscript with frozen fingers. This was a unique time to be at the University of Paris. Unsurprisingly, famines, plagues, and high prices all had their effect on student populations. Bad harvests and high prices meant fewer students. ${ }^{206}$ The thinness and

\footnotetext{
204 Overman, "The Student," 215.

205 Ibid., 85.

${ }^{206}$ Curiously, it also meant a higher proportion of poor students. Schwinges, "Admission," 193 and "Student Education," 210. Schwinges seems to contradict himself in one regard in these two articles. In
} 
poverty of the student population is attested to by an appeal to the pope for beneficial support for students and masters by the University in the year 1316, which was granted by John XXII in 1316 and $1317 .^{207}$ Although Muris was unlikely to have benefited from this assistance, ${ }^{208}$ these would have been spare years as a result of the rampant inflation, which would have greatly diminished what wealth he may have had. The evidence suggests that we should not count him among the poor students. His ability to travel, purchase and mount enormous observational equipment, and his eventual contact with royalty suggest otherwise. Additionally, at least one of his younger relatives, Julian de Murs, enjoyed a "distinguished" career which included the positions of notary and secretary to the king of France and canon of Notre Dame of Paris. ${ }^{209}$

In any event, through torrential rain, deep snow, and steep prices, Muris had to get on with the business of being a university student. During these difficult years, the strict university schedule must have lent a sense of structure to Muris's life. His days were measured by the cathedral bells marking the canonical hours on which the university's schedule was loosely based. ${ }^{210}$ Muris's days in Paris would have started quite early, at daybreak or earlier, depending on the season. Ordinary lectures, those required for all

\footnotetext{
"Admission," he states that high prices "depressed the numbers matriculating," while allowing "the number of students from poor families to increase beyond normal expectations." On the other hand, in "Student Education," he says that the poor, in their attendance, were more resilient to "external influences (e.g. wars and plagues) - with, of course, the exception of rising prices." Because the first is a measured argument and the second is an aside, I am choosing to believe that high prices increased the number of poor students in proportion to those who were not poor.

${ }^{207}$ Courtenay, Parisian Scholars, 41 n. 28; and Post, "Master's Salaries," 186.

${ }^{208}$ Excuse the pun.

${ }^{209}$ Gushee, "Murs and His Milieu," 365. Gushee has suggested that Julian may have acted as Johannes's clerc for a number of years. In any case, Julian does not appear unequivocally in the records until 1349. Ibid., 64-65. See ibid., 366-70, for Julian's (and Johannes's) possible connections with Nicole Oresme.

${ }^{210}$ The first public clock in Paris was not built until c. 1370.
} 
students, began around six. ${ }^{211} \mathrm{He}$ would have made his way through the muddy or snowcovered streets to the school of arts on Rue du Fouarre, either thankful for his nearby residence or cursing the distance. Once at school, he would sit through his morning lectures on a hay-covered floor (meant to reduce the cold, a fool's errand during the winter). ${ }^{212}$ Lectures would end sometime between nine and three (depending on the season — and whom you ask), ${ }^{213}$ and there would be time to venture out into the thick snow or miserable wet to find dinner before attending cursory (or extraordinary) lectures in the afternoon, either at the school or 'off campus. ${ }^{214}$ If there were no cursory lectures that day, perhaps Muris would go down to the College of the Sorbonne, where they had a library. To get there, he would have walked the short distance down Rue de Garlande to Grande Rue St. Jacques, which was a main street and would have been paved and less muddy than the side streets, though certainly filthy. ${ }^{215}$ Trudging along, away from the Seine, it would not have been uncommon for Muris to pass, lying at the side of the street, the thin, dead body of one who had succumbed to the pestilence that accompanied famine. ${ }^{216}$ Turning right on Rue aux Porées, he would round the block to the entrance of the College. Muris spent hours there, poring over their chained copies of Hieronymus de Moravia's Tractatus de musica and other music treatises, including Augustine's De

\footnotetext{
211 Leff, Paris and Oxford Universities, 182.

212 Overman, "The Student," 222.

${ }^{213}$ I have seen three different accounts of when morning lectures would end. Gordon Leff says between two and three. Paris and Oxford Universities, 182. Ellen Perry Pride claims ordinary lectures ended at "ten or noon, varying at different times and places." "Student Life," 267. In Hastings Rashdall's classic, Universities of Europe, we are informed that lectures in the faculty of arts in Paris usually ended at tierce in the winter and dinner time in the summer (433).

214 Leff, Paris and Oxford Universities, 182

215 Egbert, "Bridges of Mediaeval Paris," 26.

216 Jordan, The Great Famine, 142. The famine was, unsurprisingly, particularly hard on the poor. For the difficulties of their normal daily existence, see Farmer, Surviving Poverty.
} 
musica, adding marginal notes as he went. ${ }^{217}$ Completing his studies and returning home in the evening, there would be time for supper, always taken communally, and some time to study or deliberate with schoolmates (again, depending on the time of year) before the light gave out and it was time for bed. ${ }^{218}$

Through it all he had his fellow countrymen to commiserate with. Although he would not have been a member of the Norman Nation, as it was made up exclusively of masters, national cohesion was the rule, and Normans usually lived with and studied under other Normans. In Paris, Muris would have been identifiable as a Norman—even when not in the company of his countrymen—by his accent. ${ }^{219}$ His pride in his homeland (and, perhaps, in his own abilities) would have been bolstered by the Norman reputation for being ingenious and circumspect, though they were also known for having a decided fondness for libation. ${ }^{220}$ We cannot know if Muris adhered to this particular stereotype, but he probably did not do much drinking after his first few years at the University of Paris. Though the University's mandates forbade drinking, it was still a notoriously favorite pastime for students. However, the Great Famine affected more than just grains; the bad weather had disastrous effects on wine vintages beginning in 1314, and did not improve until 1321 or $1322 .{ }^{221}$ There was not just a scarcity, but what wine there was was of bad quality and increasingly expensive. For all the affliction brought on by the

\footnotetext{
${ }^{217}$ Miolo, "Jean des Murs's Library," 22.

218 Pride, "Student Life," 267.

${ }^{219}$ Contamine, "The Norman 'Nation,"' 216.

${ }^{220}$ Ibid.

${ }^{221}$ Jordan, The Great Famine, 34-35.
} 
ceaseless rain, terrible winters, and mortal famine, the biggest insult must have been to endure it all without the aid of a good glass of wine. ${ }^{222}$

\section{$\underline{\text { Study at the University of Paris }}$}

The University of Paris followed the standard Monday through Friday school week, though the academic year only contained one hundred seventy full lecture days. ${ }^{223}$ Winter break was much shorter than ours, but feast days were frequent, and four and even three-day school weeks were common. Since the middle of the thirteenth century, the works of Aristotle had made up the core arts curriculum at the university. ${ }^{224}$ Muris's education started with logic, as it was the philosopher's tool for accessing knowledge and thus key to the whole scholastic enterprise. ${ }^{225}$ Armed with the analytical techniques of logic, Muris and his cohort would tackle the "three philosophies" (or "sciences"): natural philosophy, metaphysics, and moral philosophy. ${ }^{226}$ Between the three, pride of place

\footnotetext{
${ }^{222}$ Depending on his means, Muris may still have had the opportunity to procure for himself a bit of the good stuff, as it was likely imported from the other side of the Alps, which was not affected by the Dantean anomaly. In an illuminated manuscript of the Life of St. Denis from 1317, which depicts many contemporary scenes of Paris centered around its two bridges (the Grand Pont and Petit Pont), a number of the illuminations show wine casks being shipped into the city, sold, carted away, and enjoyed (Paris, Bibliothèque Nationale, MS fr. 2090-2092, reproduced in Egbert, Bridges of Mediaeval Paris). But this does not necessarily mean that Paris was flowing with wine in 1317. Virginia Egbert points out that although the bridges were made of wood at this time (having recently been rebuilt after a flood in December 1296), in this manuscript they "are depicted as monumental stone structures." Ibid., 21. Considering this and the complete absence of adverse weather or famine in the illuminations leads me to question Egbert's assertion that "although this manuscript was intended for a king, the illuminators made no attempt to present a flattering picture of Paris." Ibid., 84. A more likely scenario is that the manuscript presents a reminder of better days in living memory, circa the third quarter of the thirteenth century. ${ }^{223}$ Overman, "The Student," 215.

${ }^{224}$ Lohr, "Medieval Interpretation of Aristotle," 87. For a good overview of the origins and curriculum of the University of Paris in the Middle Ages, see Kibre and Siraisi, "Institutional Setting," esp. 124-33.

${ }^{225}$ Weisheipl, "Aristotle's physics," 522. Bernard Dod gives this list of ten logical works prevalent after the early thirteenth century: "Porphyry's Isagoge, Categories, De interpretatione, Boethius' De divisione and De topicis differentiis, Liber sex principiorum, Prior Analytics, Posterior Analytics, Topics, and Sophistici elenchi" (all works not otherwise attributed are Aristotle's). "Aristoteles latinus," 50.

${ }^{226}$ Weisheipel, "Aristotle's physics," 521; and Grant, The Foundations of Modern Science, 47.
} 
went to natural philosophy, which centered on Aristotle's Physica and De anima. In turn the principles established in these works greatly informed the study of the two other "sciences" and much else. ${ }^{227}$ Despite the fact that Muris's education in Paris was, in large part, dedicated to an understanding of the natural world, ${ }^{228}$ and that the Aristotelian edifice was built on an empirical foundation, neither direct observation nor experiment was more than rhetorically significant in his core course of study. ${ }^{229}$ The late-medieval university curriculum was concerned with "why" the natural world works the way it does, and this involved ascertaining universal truths, not the specifics of a contingent world. ${ }^{230}$ This theoretical focus of the university notwithstanding, even a few years' study there would have equipped a student with the skills necessary to undertake a bureaucratic career, whether royal, municipal, or ecclesiastical. ${ }^{231}$ And if he was so inclined, a student could focus on mathematics, which opened doors of its own.

Muris chose the mathematical path, and it was on feast days that he got the chance to study his favorite topics: astronomy, arithmetic, geometry, and music. ${ }^{232}$ These subjects of the quadrivium had been pushed to the periphery of the arts curriculum with the ascendance of the Aristotelian corpus. ${ }^{233}$ Indeed, by the early fourteenth century, the

\footnotetext{
227 Ibid.

${ }^{228}$ Edward Grant has claimed that "it is no exaggeration or distortion to claim that the curriculum of the medieval university was founded on science and largely devoted to teaching about the nature and operation of the physical world." "Science in the Medieval University," 16.

${ }^{229}$ See Grant, "Empiricism without Observation."

${ }^{230}$ Ibid., 222.

231 Grant, Foundations of Modern Science, 49.

${ }^{232}$ Rico, "Music in the Arts Faculty of Paris," 21. Rico points out that "on very solemn feasts (e.g. Christmastide, Eastertide, Pentecost, Trinity and other celebrations) all lectures were suspended." Ibid. These feast day studies often took the form of lectures on the Rue du Fouarre, but private instruction at a master's residence was also a possibility. Ibid., 29.

${ }^{233}$ Kibre, "Quadrivium in the Thirteenth Century," 175.
} 
outdated term "quadrivium" was generally replaced by the more Aristotelian term mathematica. ${ }^{234}$ Mathematical topics were nevertheless integral to the arts curriculum. ${ }^{235}$ Just as natural philosophy was considered a prerequisite for the study of metaphysics and moral philosophy, mathematics prepared students for the study of natural philosophy. ${ }^{236}$ Of the mathematical subjects, arithmetic was principal. The standard 'textbook' for the study of the theory of number was Boethius's Institutio arithmeticae, which related the work of Nichomachus of Gerasia (c. $100 \mathrm{CE}$ ). ${ }^{237}$ This was complemented by various works of algorismus, which dealt with Arabic (or Hindu) numerals and their use for performing arithmetic calculations, most notably the Algorismus vulgaris of Johannes de Sacrobosco (Paris, 1230-55). ${ }^{238}$ Geometry was also highly esteemed not only for its

\footnotetext{
${ }^{234}$ Rico, "Music in the Arts Faculty of Paris," 25.

${ }^{235}$ This assertion has, in fact, been the source of some debate in the literature. Guy Beaujouan suggested that "the contrast between the silence of the rules and actual teaching makes one think that, in Paris, mathematics was not the subject of regular and compulsory teaching as at Oxford" ("Science in the Medieval Universities," 222). Placing the same evidence in a more thorough context, Richard Lemay countered that "it is hardly conceivable that a well-organized and vastly learned university like Paris in the fourteenth century would be in the dark concerning the identity and importance of any 'mathematical' book known to all scholars by these times" ("The Teaching of Astronomy in Medieval Universities," 214). Pearl Kibre has shown the critical role of the mathematical subjects in the scholastic project of the thirteenth century (see "Quadrivium in the Thirteenth Century," esp. 191), and James Weisheipl has found that "the curriculum of arts in the early 14th century was a full curriculum touching all the liberal arts" ("The Liberal Arts in the XIVth-XVth Century Curriculum," 213). John Murdoch has produced a number of studies that demonstrate the use of mathematics as an analytical tool in all areas of scholastic discourse in the fourteenth century (see esp. "Mathematics in Fourteenth Century Philosophy and Theology"), going so far as to label the use of logico-mathematical "measure languages" as an element of "the unification of Medieval learning" ("Unitary Character," see esp. 280-303). It is difficult to imagine this state of affairs obtaining in the absence of formal mathematical training.

${ }^{236}$ James Weisheipl observes that "the seven liberal arts at Oxford as well as at Paris were considered, not as ends in themselves, but as opera propaedeutica to the study of the three philosophies, theology, medicine and law." "The Place of the Liberal Arts," 209-10. Thomas Aquinas recommended a course of study that moved progressively from logic to mathematics to natural philosophy to moral philosophy to theology. Kibre, "The Quadrivium in the Thirteenth Century," 178-79. "In Thomas' opinion, the mathematical arts would prepare the mind, or open the way, for the apprehension and understanding of the other physical or natural disciplines." Ibid., 181.

${ }^{237}$ Ibid., 181-82. De institutio arithmeticae also served to introduce the mathematical principles necessary for understanding the material in De institutione musica, which periodically refers back to the arithmeticae. ${ }^{238}$ Ibid., 183; and Pedersen, "Astronomy," 315.
} 
practical applications (never a focus at the university) but also for its ability to illuminate natural philosophy and its usefulness for uncovering theological truths. ${ }^{239}$ Its main texts were the first six books of Euclid's Elements. ${ }^{240}$

Relying heavily on geometry (and eventually algebra and trigonometry), astronomy was highly honored by medieval intellectuals. Since antiquity, the study of the movements of heavenly bodies was of unmatched importance to the intellectually and philosophically curious. The order seen in the night sky presented a stark contrast to the ever-changing and contingent world below. Further, the movements above had an undeniable influence on the terrestrial plane. This is readily observed in the connection between the shifting tides and the phases of the moon and the way the seasonal movement of the sun affects the growth of plants and the propagation of wildlife. The effects of celestial bodies could also be extended to the realm of human activity. Throughout the Middle Ages, astronomy and astrology were not considered separate fields but rather two parts of a common subject, one which dealt with the celestial movements themselves, the other with their effects. ${ }^{241}$ The study of these physical effects was generally respectable, but one could run into trouble when crossing into the production of horoscopes and the issuing of prognostications, particularly in the early Middle Ages when church authorities took a firm and disagreeable stance on such things. ${ }^{242}$ By the thirteenth and fourteenth centuries, these restrictions began to lose their

\footnotetext{
${ }^{239}$ Ibid., 184-85. Edward Grant writes that "geometry and arithmetic were both valued because they were deemed essential for penetrating the operations of nature and for describing the variety of motions and actions in the world." Foundations of Modern Science, 46.

${ }^{240}$ Rico, "Music in the Arts Faculty," 30.

${ }^{241}$ Lemay, "The Teaching of Astronomy," 198. Additionally, the terms were often reversed.

${ }^{242}$ Lindberg, Beginnings of Western Science, 274.
} 
teeth, ${ }^{243}$ and astrology became increasingly valued for its benefit to society. ${ }^{244}$ As an increase in natural calamities heightened the demand for and reliance on astrologers, however, orthodoxy continued to require the maintenance of free will and some scholars continued to decry astrological charlatanism. ${ }^{245}$

For Christian scholars, astronomy had long been necessary for the calculation of the liturgical calendar, ${ }^{246}$ and Sacrobosco's Computus $(1235 ?)^{247}$ served as an introduction to astronomical time reckoning in the arts curriculum. ${ }^{248}$ Also by Sacrobosco, De sphere (by $1220 ?)^{249}$ related the mathematical astronomy of Ptolemy (without the mathematics), its clarity and elementary nature making it an ideal required text. ${ }^{250}$ More detailed (and thoroughly mathematical) but still elementary was the anonymous Theorica planetarum (c. 1260-80), ${ }^{251}$ which enjoyed wide popularity. ${ }^{252}$ Students like Muris, who specialized in astronomy, would have gone straight to the source; Ptolemy's Almagest was the primary authority on mathematical astronomy since its translation in the second half of the twelfth century, as it showed the way for constructing geometric models for celestial predictions, creating numerical parameters through accurate observation, and condensing that data into tabular form. ${ }^{253}$

\footnotetext{
243 Ibid., 277; and Pedersen, "Astronomy," 304.

244 Lemay, "The Teaching of Astronomy," 198.

${ }^{245}$ Lindberg, Beginnings of Western Science, 279-80; and Pedersen, "Astronomy," 304.

246 Ibid.

247 Thorndike, "Introduction," 8.

248 Rico, "Music in the Arts Faculty of Paris," 30.

249 Thorndike, "Introduction," 14.

${ }^{250}$ Ibid., 1 and 42.

${ }^{251}$ Grant, Source Book in Medieval Science, 451.

252 Pedersen, "Astronomy," 316.

${ }^{253}$ Ibid., 313-14.
} 
It is worth noting here that there was a conflict between Ptolemaic mathematical astronomy and Aristotelian cosmology. Although both imagined a cosmos made up of concentric spheres, Aristotle's perfect circles were not borne out by close observation, the results of which Ptolemy explained by positing epicycles and eccentrics. ${ }^{254}$ That is, mathematical astronomy was not in perfect accord with Aristotelian physics. Similar to the way thirteenth-century theologians (particularly Thomas Aquinas) sought to reconcile Aristotelian "science" with biblical "truth," some philosophers and astronomers attempted to find a compromise between these two cosmological visions. ${ }^{255}$ Ultimately, accurate prediction was too highly valued to be suppressed by a tidy Aristotelian universe. ${ }^{256}$

Throughout the thirteenth and into the fourteenth century, the Almagest was complemented by a slew of technical astronomical treatises and astronomical tables (many of Islamic origin), which allowed for easier and more accurate calculations. ${ }^{257}$ It should be noted, however, that the average student, though introduced to the general concepts of mathematical astronomy, was unlikely to come away from his arts education with anything close to a sophisticated knowledge of the workings of the cosmos or the complex mathematics (geometry, algebra, and trigonometry) necessary for making accurate predictions. ${ }^{258}$ Muris was not an average student in this regard. He ranked among a small group of astronomers in early fourteenth-century Paris who made great advances in the science of astronomy, particularly in the recasting of the Alfonsine tables,

\footnotetext{
${ }^{254}$ Ibid., 320-21; Grant, Foundations of Modern Science, 104-05; Lindberg, Beginnings of Western Science, 271.

${ }^{255}$ Ibid., 271-72; Grant, Foundations of Modern Science, 105-07.

${ }^{256}$ Lindberg, Beginnings of Western Science, 272; Pedersen, "Astronomy," 321-22.

${ }^{257}$ Ibid., 319.

${ }^{258}$ Lindberg, Beginnings of Western Science, 272.
} 
which became the standard up to the time of Copernicus. ${ }^{259}$ Muris has been credited for key innovations that led to the success of these astronomical tables. ${ }^{260}$ The production of these innovations required complex calculations, but their result was an enormous simplification for the users of the tables, greatly reducing the number of calculations required of astronomical practitioners. ${ }^{261}$ That user-friendliness was a conscious and continuing goal of Muris is attested to by these lines from the introduction to his Tabulae permanentes (1330): "Since I found that a very great number of the tables constructed for this purpose are difficult because of the large number and length of the calculations, or because, even if they are easy, they are nevertheless of short durability, I have decided to construct tables that are easy to use, to the point that, in a very short time interval, the true conjunctions and oppositions can be calculated for many years."262 Although he did not start producing his work on the Alfonsine tables until 1321, two years after the end of our period, Muris would have had to be diligently honing his mathematical and astronomical skills throughout his university years in order to deliver at that level of sophistication.

Whereas a rudimentary knowledge of astronomy was essential for computus, an important clerical and priestly skill, the quadrivial subject of music - that is, speculative music - had no such corollary. The practical skills necessary for the singing of chant in

\footnotetext{
${ }^{259}$ Ibid. and Chabás and Goldstein, "Tables of 1321," 297. For this group of Parisian astronomers, see Chabás and Goldstein, "The Astronomers in the Alfonsine Tradition in Paris," in Alfonsine Tables of Toledo, 266-90.

${ }^{260}$ Chabás and Goldstein, "Tables of 1321," 318.

${ }^{261}$ Ibid., 317.

262 "Cum igitur quamplurimas tabulas propter hoc factas invenissem difficiles propter operacionum multitudinem ac prolixitatem, aut si faciles modice tamen durabilitatis, volui tabulas componere quarum stilus facilis est, adeo ut pro multis annis coniunctiones et opposiciones vere in valde modico tempore possunt adequari ..." Text and translation in Porres and Chabás, "Tabulae Permanentes," 67.
} 
the liturgy were taught in cathedral and parish schools. As a subject of the quadrivium, music was a mathematical discipline concerning quantities related to other quantities, that is, 'ratio' and 'proportion. ${ }^{263}$ Throughout the Middle Ages, the premier authority on speculative music was Boethius, who wrote De institutione musica in the first decade of the sixth century. Of its five books, the first two were required 'reading' for arts students at the University of Paris. ${ }^{264}$ This does not, however, imply in that readership a thoroughgoing knowledge of De institutione musica's first two books. In fact, it is likely that most students did not even have access to the texts themselves and relied on lecture material, student handbooks, and abbreviations to study for their examination questions. ${ }^{265}$ In his Ars musice (c. 1275), Johannes de Grocheio lamented that although many in Paris "seek out the practice of this art, few, however, pay attention to its theory." ${ }^{266}$ Muris himself noted that the ancient musical and mathematical writings were not read. ${ }^{267}$ The comment appears in the prologue of his Musica speculativa (1323/25), which abridged, largely revamped, and eased the difficulty of De institutione musica. ${ }^{268}$

\footnotetext{
${ }^{263}$ Boethius defines the subjects of the quadrivium this way: "Geometry speculates about fixed magnitudes, while astronomy pursues knowledge of movable magnitude; arithmetic is the authority concerning quantity that is discrete in itself, whereas music is clearly expert concerning quantities related to other quantities." Boethius, Fundamentals of Music, 54. "Sed inmobilis magnitudinis geometria speculationem tenet, mobilis vero scientiam astronomia persequitur, per se vero discretae quantitatis arithmetica auctor est, ad aliquid vero relatae musica probatur obtinere peritiam." Boetii De institutione musica, 229.

${ }^{264}$ Rico, "Music in the Arts Faculty," 73.

${ }^{265}$ Ibid., 36. For a description of the contents of student handbooks on De institutione musica, see ibid., 4451. For the corresponding description of abbreviations, see ibid., 55-64.

266 "Licet enim plures diebus istis practicam huius artis querant. [P]auci tamen de eius speculatione sunt curantes." Grocheio, Ars musice, 42-43.

267 "Verum quia diebus istis libri antiquorum philosophorum, nedum de musica, se et de ceteris mathematicis pluribus non leguntur et ob hoc accidit eos tamquam inintelligibiles aut nimis difficiles abhorreri." Muris, Musica $<$ speculativa, $>4$. Susan Fast calls attention to this in the introduction to her critical edition. Ibid., $\mathrm{x}$.

${ }^{268}$ Muris's Musica speculativa became a popular textbook in its own right, not necessarily in Paris but certainly in German universities in the next two centuries. Ibid., ix.
} 
Indeed, although musica was considered a mathematical science, Gilles Rico has shown that its study at the university in our period avoided the complex arithmetic of Boethius and focused instead on epistemological issues, definitions, and consonance theory, selectively reworking De institutione musica into an Aristotelian framework based on logic and natural philosophy. ${ }^{269}$ Muris's study of speculative music clearly went far beyond the meager requirements of an arts student. He mastered the difficult content of Boethius's De institutione musica sufficiently to summarize it in the first book of the Notitia artis musicae and more fully a few years later in his Musica speculativa. ${ }^{270}$ And, as we have seen, Muris complemented his knowledge of both speculative and practical music through the close study of Hieronymus of Moravia's compendium, which amounted to an up-to-date (for the late thirteenth century) 'state of the field' and drew from the most prominent writings on both speculative and practical music of the ancients and moderns. ${ }^{271}$

Along with his fellow arts students, Muris received a thoroughly Aristotelian education centered on logic and natural philosophy as well as metaphysics and moral philosophy. But while students with a few years of university study under their belts would certainly have been numerate and may have been familiar with the general contours of the subjects of astronomy and music, Muris excelled in these subjects that required considerable extra training and sophisticated mathematical expertise. These

\footnotetext{
${ }^{269}$ Rico, "Music in the Arts Faculty of Paris," 74 and 148. Two quodlibetal questions from 1301, recently described by Joseph Dyer, demonstrate an interest in the effects of music to induce both "the passions" and good moral behavior. Significantly, while citing De institutione musica, Pierre d'Auvergne's responses rely heavily on Aristotelian natural philosophy. "Music, Passion and Virtue."

${ }^{270}$ In Musica speculativa, Muris recast the contents of De institutione musica in a form more resonant with the academic disposition of the fourteenth century. Muris, Musica $<$ speculativa, $>$ x-xi.

${ }^{271}$ Weber, "Intellectual Currents," 2-3; Moravia, Tractatus de musica, v.
} 
specialized skills became the backbone of a successful career that would bring him into contact with royalty and pope alike..$^{272}$

\section{$\underline{\text { Musical life in Paris }}$}

But life was not all toil. ${ }^{273}$ Muris complemented his study of music with experience and enjoyment of its performance. ${ }^{274}$ Weekends and solemn feast days were occasions for Muris to be exposed to the rich musical life Paris had to offer. If perhaps only on special occasions, Muris may have crossed the Petit Pont to attend service at Notre Dame de Paris, with its superlative choir (both architectural and musical) and ornately adorned polyphonic chant settings. ${ }^{275}$ Mid-to late-thirteenth-century Parisian service books contain a dazzling array of chant settings for liturgy and feast days in three and sometimes even four voices. ${ }^{276}$ But although the cathedral had long been the locus of polyphonic innovation, by Muris's time it was no longer associated with the musical avant-garde. ${ }^{277}$

The motet was the song form most closely associated with compositional (and notational) innovations throughout the thirteenth century and into the fourteenth, and a

\footnotetext{
${ }^{272}$ Gushee, "New Sources," 8 and 16. The successes of Muris's career are neatly summarized in Desmond, Music and the moderni, 73.

${ }^{273}$ For "toil," read "academics."

${ }^{274}$ At the beginning of his Nine Conclusions, which were appended to the Notitia, Muris mentions that he has delighted in venerable musicians since his earliest youth because of music: "venerabiles musici, quos a tota dileximus iuventute ratione musicae." Michels, Notitia, 106.

${ }^{275}$ See Ch. 6, "Notre Dame de Paris," in Taruskin, Music from the Earliest Notations, 169-205. For an excellent and thorough discussion of the musical life of Notre Dame, see Wright, Music and Ceremony. 276 Taruskin, Music from the Earliest Notations, 171. Muris, however, would not have been able to see the proceedings at Notre Dame because of a stone enclosure that separated the people of Paris from the sanctuary, the construction of which began in 1304. Wright, Music and Ceremony, 7-12.

${ }^{277}$ Ibid., 344.
} 
summary of its development in the cathedral and evolution into a secular form will help us understand the literate-music scene that Muris entered into. Originally created by adding a non-liturgical text to an existing discant clausula (a piece of note-against-note polyphony itself built on an existing chant), the early motet was a product of accretion in which texts and melodies were repurposed and added to. ${ }^{278}$ In their early form, motets served a liturgical or paraliturgical function, but as they evolved, secular and fully newlycomposed motets began to be written, and the motet soon became a popular secular song form. ${ }^{279}$ Vernacular lyrics corresponding to courtly genres of the trouvère began to be added as motets became increasingly complex with two, three, and four voices all singing different texts in counterpoint. The development of the motet, particularly as a secular genre, has been linked to the intersection of cathedral and court. ${ }^{280}$ Movement between these environments was not uncommon, and cathedral-trained singers and composers could find employment in both, the resulting cultural exchanges contributing to the "hybrid" motet. ${ }^{281}$

\footnotetext{
${ }^{278}$ Gushee, "Polyphonic Music," 164. Clasulae themselves were the place of early compositional experimentation that engendered some of the founding principles of counterpoint. Rudolf Flotzinger, "Clausula," Grove Music Online, 2001; accessed July 20, 2020.

${ }^{279}$ Everist, "Thirteenth Century," 80; Gushee, "Polyphonic Music," 164.

280 Taruskin, Music from the Earliest Notations, 218-19.

${ }^{281}$ Everist, "Thirteenth Century," 85. Taruskin writes that "the motet in French was thus an interesting hybrid, crossbred from two exceedingly disparate strains." Music from the Earliest Notations, 219.
} 
Table 1 Notes described in Franco's Ars cantus mensurabilis

\begin{tabular}{lll}
\hline Note shape & $\begin{array}{l}\text { Value in } \\
\text { tempora }\end{array}$ & Note name \\
\hline & 6 & duplex longa \\
\hline & 2 & longa perfecta \\
\hline & 2 & brevis altera \\
\hline & 1 & brevis recta \\
\hline & $2 / 3$ & semibrevis maior \\
\hline
\end{tabular}

Adapted from Busse Berger, "Evolution of Rhythmic Notation," 632

The requirement that the syllables of a motet's texts be closely matched to their melodies soon revealed certain inadequacies of the notational system, which in turn served as inspiration for theorists to greatly modify and expand it. ${ }^{282}$ The rhythmic notation of the early thirteenth century used a prescribed set of rhythmic modes (set rhythmic patterns), representing them with ligatures (graphemes that represent a group of pitches), the shape of which determined the mode. ${ }^{283}$ This notational system proved too cumbersome and imprecise to meet the needs of the increasingly complex motets. To meet those needs, a new, more precise notational system, known as "mensural," was developed, which designated individual graphemes, or note shapes, for each time-interval (see Table 1). The most definitive description of mensural notation was written by Franco of Cologne, whose Ars cantus mensurabilis (c. 1280?) became the standard authority. ${ }^{284}$

\footnotetext{
${ }^{282}$ Taruskin, Music from the Earliest Notations, 214.

${ }^{283}$ Pesce, "Theory and Notation," 283.

${ }^{284}$ For a critical edition and translation, see Scott, "'Ars cantus mensurabilis."' The traditional dating of this treatise is between 1250 and 1260, but Scott, referencing "recent research" and the content of the treatise
} 
There are two defining characteristics of "Franconian" notation that are worth noting because they are so foreign to modern notation: (1) All sanctioned rhythms were ternary, and (2) the rhythmic value of a given note shape depended on the notes that surrounded it. A longa perfecta was worth three tempora (the basic measuring unit, equal to one brevis), but if a brevis was placed between two longas, the first would be "imperfected," becoming a longa imperfecta, worth only two tempora -while maintaining its note shape - thus leaving the ternary rhythm intact. In addition to the longa and brevis, which were described by slightly earlier mensural theorists, Franco introduced the semibrevis, which functioned relative to the brevis as the brevis to the longa, though there was some ambiguity in this relationship. The semibrevis allowed for a more intricate rhythmic texture, something motet writers were pushing for. Already by the 1290s, composers unsatisfied with the rhythmic density allowed by the Franconian semibrevis began to divide the brevis into as many as nine semibreves. ${ }^{285}$ This intricacy and rhythmic division, along with increasingly complex text-music relationships, exemplifies the aesthetic ideal of motet writers and is neatly captured by the commonly used term subtilitas.

In his designation of an "audience" for late-thirteenth-century motets, ${ }^{286}$ Johannes de Grocheio used the word "subtlety" twice (subtilitatem, subtilitates): "This cantus ought

favors a date of after 1279. The two sources he cites are from 1940 and 1970. Ibid., 2. Mews, et al., support the traditional dating of 1250-1265, although they recognize that "further research is needed." Grocheio, Ars musice, 12. See also Busse Berger, "Rhythmic Notation," 631-35.

${ }^{285}$ Pesce, "Theory and Notation," 284; Taruskin, Music from the Earliest Notations, 236-45. Referenced in contemporary sources was Petrus de Cruce (fl. c. 1290), a composer and theorist who allowed for the division of the brevis into up to seven semibreves. This accompanied a structural change in cutting-edge motets of the late thirteenth century whereby the individual lines were more clearly stratified and distinct. 286 The writing of this description likely predates the "Petronian" division of the semibrevis. Grocheio, Ars musice, 10-11. 
not to be celebrated in the presence of common people, because they do not notice its subtlety, nor are they delighted in hearing it, but in the presence of the educated and of those who are seeking out subtleties in the arts. And it is customarily sung at their feasts for their enhancement, just as the cantilena that is called a rotundellus [is sung] at feasts of the common laity." 287 Karen Desmond has recently described the "multivalence" of this term in our period. ${ }^{288}$ Although the idea of subtilitas could be used pejoratively to decry superficiality_-"unnecessary complexity, invoked by youthful practitioners eager to dazzle with stylistic superfluities"—-to theorists and composers alike, it denoted precision, intricacy, division, and complexity, a fine craft that required concentration to understand and appreciate. ${ }^{289}$ This ideal dramatically affected the lyrical, structural, and rhythmic character of these songs. Thirteenth-century motet composers exploited the form's multi-textuality to produce a soundscape in which texts, rhythms, and melodies interacted with each other through concordances, contrasts, and cross-references. ${ }^{290}$ The appeal of motets for the listener came not only from their exciting textures and new harmonic landscapes but also from the reward of discovering the structural complexities a close and discerning listening had to offer. ${ }^{291}$

Grocheio made it clear that motets were not for everyone; only those with an ear for subtleties would 'delight in hearing' them. The question of who those people were and

\footnotetext{
287 "Cantus autem iste non debet coram vulgalibus propinari. Eo quod eius subtilitatem non advertunt nec in eius auditu delectantur. Sed coram litteratis et illis qui subtilitates artium sunt querentes. Et solet in eorum festis decantari ad eorum decorationem, quemadmodum cantilena que dicitur rotundellus in festis vulgalium laycorum." Text and translation in Ibid., 84-85. Cf. the reference to the rotundellus in the Grocheio quote on p. 44, above.

${ }^{288}$ See Desmond, Music and the moderni, 36-47.

${ }^{289}$ Ibid., quote on p. 39.

${ }^{290}$ Page, Discarding Images, 99-110

${ }^{291}$ Ibid., 110.
} 
in what context they experienced motets is not easily answered and continues to be the source of some debate in modern scholarship. ${ }^{292}$ But with relative assurance, we can put together a rough sketch. Craig Wright has shown that in the first half of the thirteenth century, the clerical elite at Notre Dame took an interest in and even wrote texts for motets (and conductus, another polyphonic song genre). ${ }^{293}$ As the texts for many of these songs were not suitable for the liturgy, Wright has suggested that they were sung in the private quarters of canons during celebrations on feast days and for recreation. ${ }^{294}$ It seems likely that the canons and their clerical families would have invited guests that included lay-persons to these celebrations. We have another enticing passage, this one from the second quarter of the fourteenth century, that opens a small window into the performance context for the motet:

I saw, in a certain gathering in which skilled singers and discerning lay persons were assembled, that modern motets were sung there according to the modern manner, and some old [motets]. The old motets, and the old manner, gave more pleasure - to the lay persons also - than the new ... I saw in a great gathering of discerning people, when motets were sung according to the modern manner, that it was asked what language the singers were using: Hebrew, Greek, or Latin. ${ }^{295}$

\footnotetext{
${ }^{292}$ See Ch. 3, "Johannes de Grocheio, the Litterati, and Verbal Subtilitas in the Ars Antiqua Motet," in Page, Discarding Images, 65-111, for a critique of the popular opinion that motets were performed for an intellectual elite. For "coram litteratis et illis qui subtilitates artium sunt querentes," Page suggests "before the clergy and before those who seek the refinements in any branch of study." Ibid., 82. Further exploring the term litterati, he finds that "a litteratus is any cleric who is pursuing some kind of study with a view to acquiring scientia, intellectus, sensu, or sapientia, terms that encompass both more and less than the modern and wholly secularized concept of 'learning."' Ibid., 83. This is a good reminder that we should not be too restrictive (or prescriptive) in designating the 'audience' for motets, though it does not dispel the notion that a certain refinement of taste was required for the enjoyment of motets nor that they would have held a special appeal for the educated. In arguing against a sophisticated and intellectual audience for motets, Page points up a lack of scholasticism's mark on motet lyrics and the absence of Aristotelian themes, concluding that, "on the whole, the repertoire of motet verse, both French and Latin, seems more lyrical and recreative than intellectual." Alex J. Novikoff, however, sees in some motet lyrics a "situation analogous to a scholastic disputation." Medieval Culture of Disputation, 149.

${ }^{293}$ Wright, Music and Ceremony, 32.

${ }^{294}$ Ibid., 32-33. This squares with Christopher Page's translation of Grocheio's "coram litteratis" as "before the clergy." See n. 292, above.

295 "Vidi ergo, in quadam societate, in qua congregati erant, valentes cantores et laici sapientes. Fuerunt ibi canatati moteti moderni et secundum modum modernum, et veteres aliqui. Plus satis placuerunt, etiam
} 
It should be noted that this passage, by a certain Jacobus, appears in a work that criticized the innovations of Muris and his generation and sought to defend the older style that we have been discussing. ${ }^{296}$ Nevertheless, we get a glimpse of "great gathering" of singers and music enthusiasts, where both the 'old hits' and 'fresh new tunes' were performed followed by or interspersed with conversation and critique. We now also get confirmation of the presence of lay-people, ostensibly in the company of clerics ("to the lay persons also").

A unique treatise by Arnulf de St. Ghislain sheds some light on what this kind of musical gathering looked like at the turn of the fifteenth century. ${ }^{297}$ The treatise outlines "the different kinds and degrees of musicians" at one of these events, of which Arnulf identifies four. ${ }^{298}$ The first is "utterly ignorant of the art of music," a terrible singer, and

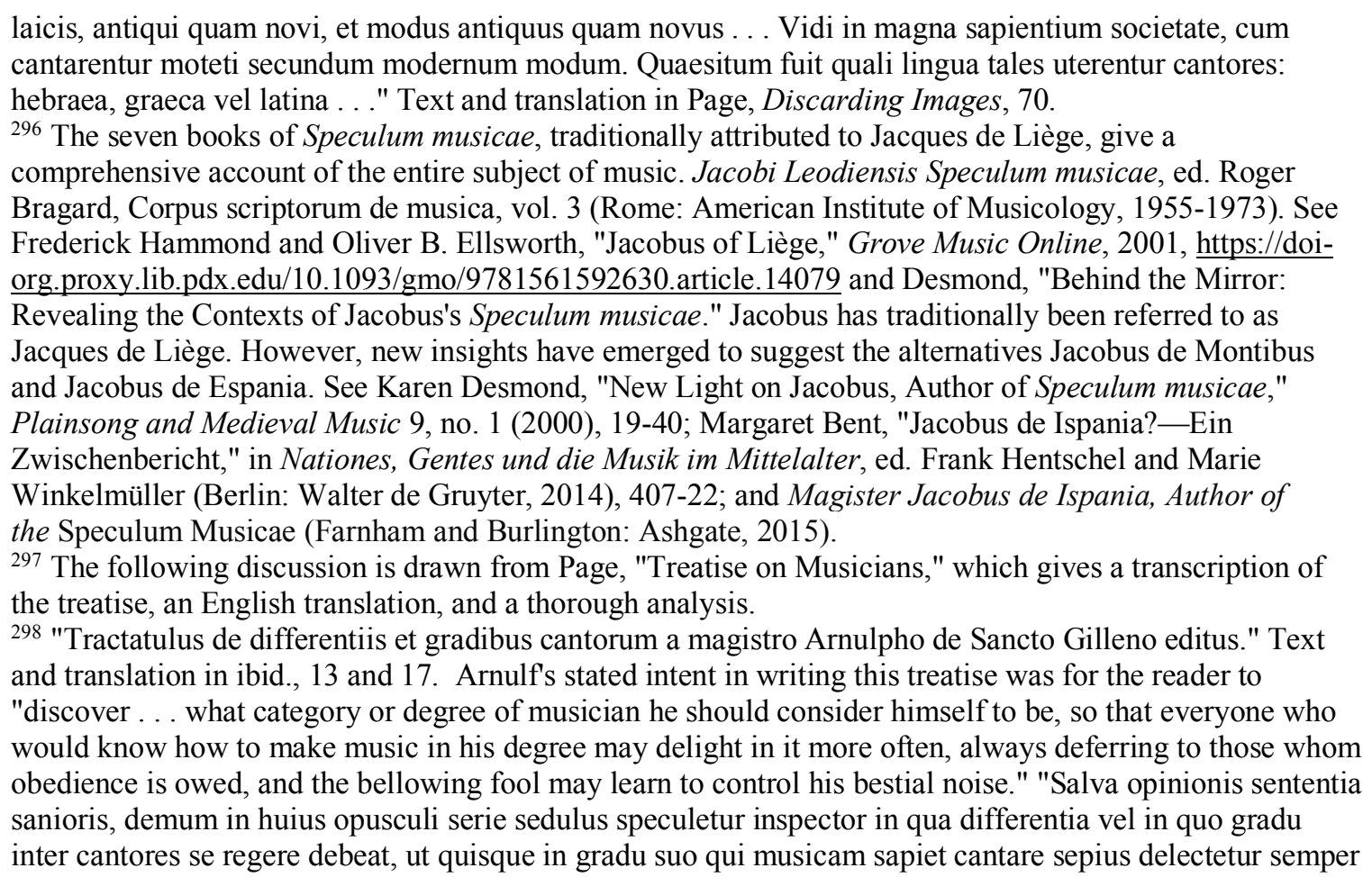


worst of all arrogant and presumptuous. ${ }^{299}$ Arnulf makes no secret of his desire that these people not show up to the party. The second category is also unskilled, but they are pleasant and truly love music. Their willingness to learn from the skilled musicians paired with their industriousness and practice "can make good their deficiency in art."300 The third kind "keep the glorious treasures of the art and discipline of music in the sanctuaries of their breasts, acquired in a praiseworthy fashion by the efficacy of study."301 These theorists may not be able to carry a tune, but they are valuable for their understanding of the rules of music and ability to instruct the others at the appropriate level. The final type is the superlative musician, who not only has innate musical talent and a sweet voice, but has also acquired the "noble art of singing," which "guides such a singer's voice according to rule in modus, measure, number and color."302

The word Arnulf used for this group was "turba," which Christopher Page has rendered "throng," while pointing out that the Middle-French tourbe at the time could mean "a gathering of 26 people." ${ }^{303}$ Without adopting that specificity, we get the picture of a fair-sized group, which corresponds neatly with Jacobus's "great gathering." ${ }^{304}$ In this group, we find clerics and lay-persons (even women!) of all skill levels. All are participating in one way or another, thus blurring the line between 'performer' and

hiis quibus debetur maioritas deferendo, ululansque ferinum discat ydiota suum continere tumultum." Ibid., 17 and $20-21$.

${ }^{299}$ Ibid., $17-18$.

${ }^{300}$ Ibid., 18-19.

301 "Tertia est et aperte comprobatur in illis qui in suorum sacrariis pectorum gloriosos possident artis et discipline musicalis thesauros virtute studii laudabiliter acquisitos." Ibid., 15 and 19.

302 "In quibus nobilis acquisitio artis cantorie organum naturale dirigit regulariter in modo, mensura, numero et colore." Ibid., 16 and 19.

${ }^{303}$ Ibid., 10.

${ }^{304}$ Jacobus, however, used the word "societas," which Page takes to be "more serene." Ibid., 9. 
'audience.' And the whole affair is woven through with conversation. The arrogant 'musicians' of the first group "give correction or leadership to these same [excellent singers] so that they ... may give the appearance of being trained musicians," and "they cannot be silenced." 305 The second group "may be of one mind with accomplished musicians by conversing with them in a more pleasant fashion." ${ }^{306}$ The learned musicians in the third group, which would include Muris if had he been alive at the time, "teach their pupils to perform what they cannot perform themselves by instructing them according to rule and by sharing musical riches and pearls with them, revealing the secrets of music in a fitting fashion to those fit to receive them." ${ }^{307}$ Not without its strife and annoyances, this is a mixed group of music lovers working together to enjoy and perfect their art. Given that Arnulf's treatise was written some eighty years after our period, we should be cautious in applying its fine details to Muris's experience. Nevertheless, Arnulf seems to have described a later version of the same social scene we have seen from Grocheio and Jacobus.

There is no way to tell how long it took Muris to network himself into these musical events, but when he did, he would have heard the 'classic' motets of the thirteenth century alongside the newer but no longer cutting-edge 'Petronian' motets. ${ }^{308} \mathrm{He}$ would also surely have heard the latest developments that were beginning to emerge just as he got to Paris, developments born out of composers' experimentation with "logical

\footnotetext{
305 "Corrigere vel dirigere se impudenter offerunt ut apud homines musici videantur . . . . Nec imponi potest silencium." Ibid., 15 and 18.

306 "In plerisque cum cantoribus gratius garriendo concordent." Ibid., 15 and 18-19.

307 "Quod per se promere notaliter consonando nequeunt per discipulos fieri procurant, propositos regulariter edocendo ipsisque musicales communicando divitias et margaritas, Musice digne dignis revelando secreta." Ibid., 16 and 19.

${ }^{308}$ See n. 285.
} 
integrative procedure[s]" associated with the lengths of phrases and their rhythms. ${ }^{309}$ One audacious and talented young composer, named Philippe de Vitry, pushed this idea further than any other, writing motets in which the text was subordinate to a fullyschematic structure. ${ }^{310}$ Vitry stands out as a pioneer of compositional innovation, recognized by his contemporaries, subsequent generations, and modern scholars alike. ${ }^{311}$ In addition to his "systematization in structure and rhythmic language," Vitry made use of a note value smaller than the semibrevis, the semibrevis minima, devising rules for its use, though at first it did not carry its own note shape. ${ }^{312}$ Significantly, Vitry also wrote motets that divided the various note shapes into two equal parts, stepping beyond the prescribed ternary division of Franco. ${ }^{313}$

Considering the context in which Muris experienced these new motets, he must have had ample opportunity to discuss their subtleties and innovations with trained singers and enthusiasts, if not Vitry himself. ${ }^{314}$ In these discussions, Muris and his

\footnotetext{
${ }^{309}$ Leech-Wilkinson, "Emergence of ars nova," 292-95. In his analysis of a group of motets from the years 1313-15 (?), Leech-Wilkinson sees "composers aware of the desirability of an underlying scheme. They are not always agreed about what it should be, but they do agree that it is only a framework and that modifications are necessary for the sake of better text setting." Ibid., 295. As we will see, this agreement was about to be challenged.

${ }^{310}$ Ibid.

${ }^{311}$ For a concise yet thorough biography, see Bent and Wathey, "Vitry, Philippe de," Grove Music Online. Sarah Fuller has argued against a notion that had become common coin in musicological scholarship, that Philippe de Vitry wrote a treatise on ars nova theory. Although Vitry's prominence as an ars nova innovator is well-attested in the primary sources, Fuller found lacking the evidence for a treatise under his authorship, arguing instead that the group of divergent treatises thought to be witnesses to a non-extant urtext are in fact representatives of a "teaching tradition" (42-44). In "Did Vitry Write an Ars vetus et nova?" Karen Desmond directly challenged Fuller's hypothesis, "which has won general acceptance in the musicological literature" (485). Using evidence found in Jacobus's Speculum musicae and the treatises associated with Philip de Vitry's theory, Desmond convincingly argued that Jacobus cited a written treatise most likely written by Vitry himself.

${ }^{312}$ Leech-Wilkinson, "Emergence of ars nova," 316.

${ }^{313}$ Leech-Wilkinson, "Ars Antiqua-Ars Nova-Ars Subtilior," 223.

314 There is no extant evidence that Muris and Vitry knew each other at this time, though they certainly did later. Muris is known to have loaned several books to Vitry (Karen Desmond has suggested the 1330s), and
} 
associates likely wrestled with the validity of those innovations and their proper method of notation, particularly of the smallest notes. Differing opinions and debate were endemic to this entire period of rapid notational development. Franco of Cologne's mensural theory was not the only one of its time but simply the most successful. ${ }^{315}$ In its introduction, he wrote "since we have seen many people (both ancients and moderns) say many good things about polyphony in their respective arts, but on the other hand fail and err in their knowledge of many things, and especially regarding peripheral topics, we think we should come to the aid of their opinions." ${ }^{316}$ Grocheio likewise wrote of a "plurality of opinions" from which one must extract what is true. ${ }^{317}$ Muris himself, at the beginning of Book II of his Notitia artis musicae, mentioned the disagreements of practitioners as a motivation for writing it: "Seeing that in the preceding discussion we have touched lightly and in brief on the theory of music, now it remains to investigate more broadly the practice of it [music], that part through which it is measurable, since various practitioners think about it in diverse ways" (my italics). ${ }^{318}$ Diverse solutions to theoretical problems begged for an authoritative resolution, despite the fact that musical practice would continue to evolve.

\footnotetext{
Muris's Quadripartitum (1343) is dedicated to Vitry. Desmond, Music and the moderni, 13 and 198-199. For the book loans, see also Gushee, "New Sources," 13 and Miolo, "Jean de Murs's Library," 25.

${ }^{315}$ Busse Berger, "Rhythmic Notation," 632.

316 "Quoniam cum videremus multos, tam novos quam antiquos, in artibus suis de mensurabili musica multa bcma dicere et e contrario in multis, et maxime in accidentibus, ipsius sciencie deficere et errare. opinioni eorum fore existimamus succurendum." Text and translation in Scott, "'Ars cantus mensurabilis,"' 90-91.

317 "Videmus enim diligenter considerantes pluralitatem opinionum querere et ex illis extrahere quod est verum." Grocheio, Ars musicae, 42-43.

318 "Quoniam in antepositis sermonibus theoricum musicae leniter tetigimus et in brevi, nunc quoque de eius practica, ea parte, qua mensurabilis est, restat diffusius inquirendum, cum de ipsa diversi diversimode sentiant practicantes." Michels, Notitia, 65.
} 
Even as Muris's experience of practical music was fundamentally social and his study of speculative music was essentially extra-curricular, he approached contemporary musical concerns with the same innovative spirit, mathematical seriousness, and reliance on both authority and observation that he applied to his astronomical work.

\section{Observation in Normandy}

As Muris progressed through his studies and embedded himself in the rapidlydeveloping and often contentious musical culture of his peers, the winter of 1317/18 topped them all for its ferocity. The situation in Paris would have been dreary and desperate. Muris's homeland, however, fared the resulting famine less disastrously than other regions, especially in the countryside. Normandy's orchards with their copious fruit trees were less susceptible to the ravaging that grain crops endured. ${ }^{319}$ Although we do not know exactly when he relocated, by 1319 Muris had taken up temporary residence ("pro tempore degens") in Évreux, Normandy. ${ }^{320}$ Was this move taken in an effort to escape the worst of the Parisian winters and famine? Did he receive an invitation he could not pass up? $?^{321}$ What we do know is that while he was there on March 13, it was clear enough for Muris to observe the sun's meridian altitude, marking the vernal equinox. ${ }^{322}$

\footnotetext{
319 Jordan, The Great Famine, 120.

${ }^{320}$ Poulle, "Les tables Alphonsines," 265. In that same year, Normandy was torn up by terrible wind storms that played havoc on the fruit trees, sheep, and fowl. Jordan, The Great Famine, 19.

${ }^{321}$ Philip III of Navarre/Évreux (1306-1343), in whose household Muris would later serve as clerc, became comte d'Évreux in this year. Whether there was already a relationship between the two at this time is not known.

${ }^{322}$ Northaft, "A Problem of Authorship," 210.
} 
Muris wrote of this observation in his Expositio intentionis Regis Alfonsii (1321), ${ }^{323}$

which was, according to Emmanuel Poulle,

"presented as a technical study of the values

given by the Alfonsine tables for the

composite movement of the apogees of the

planets and for the mean movement of the

sun." 324 To make this observation, Muris

employed a massive instrument. Mounted

as vertically as possible to solid stone,

Muris's kardaga ${ }^{325}$ had a radius of fifteen

feet! ${ }^{326}$ Olaf Pedersen called this "the

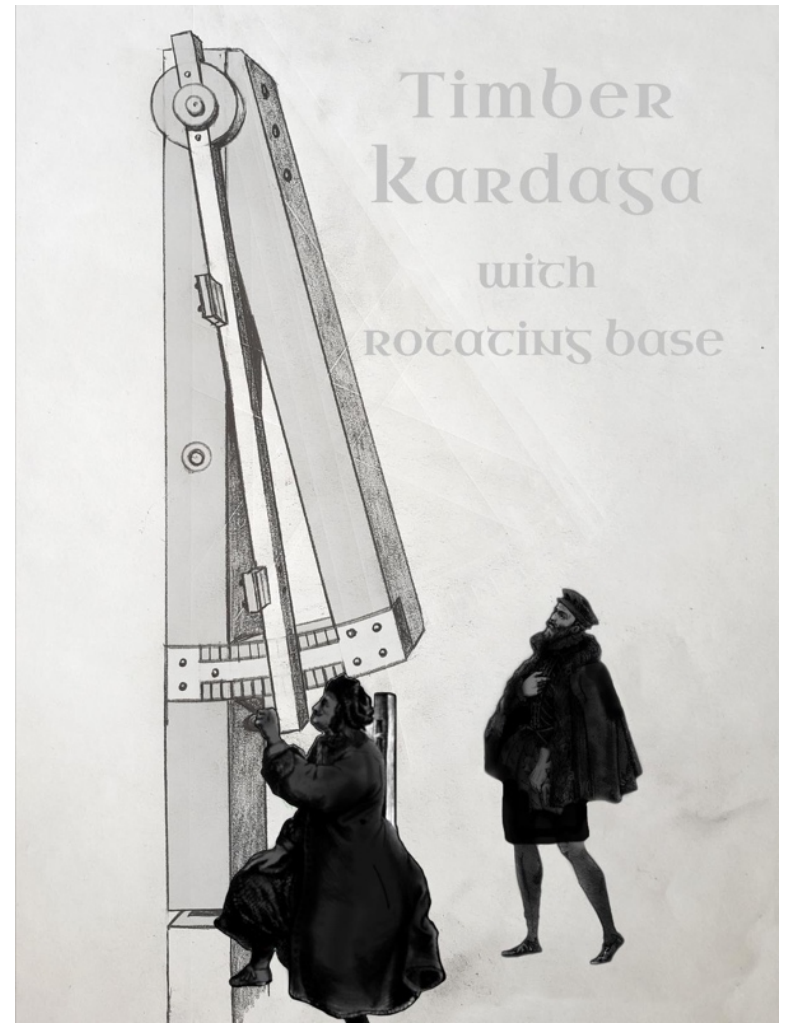

earliest known record of a large

Figure 3 Artist's interpretation of Muris's kardaga (drawing by Jonathan Ash (C)

\footnotetext{
${ }^{323}$ The Expositio survives in one fifteenth-century manuscript, Paris BN 7281 (fols. 156v-160r). There are some discrepancies in the reporting of the date of this observation. For the year, see n. 136. Lynn Thorndike gave March, 12 instead of 13. Magic and Experimental Science, 3:294. It is true that the date of March 12 appears multiple times on fols. 159v-160r. I have consulted a high-resolution image of the manuscript, and the number in question is clearly a thirteen (gallica.bnf.fr / Bibliothèque nationale de France. Département des manuscrits. Latin 7281). An edition of the Expositio can be found in Poulle, "Les tables Alphonsines," 250-68.

${ }^{324}$ Poulle, "John of Murs," 130. C. Philipp Nothaft notes that this treatise "is a key document for the early reception of the Alfonsine Tables in the Latin form that became known in Paris." "Critical Analysis," 77. ${ }^{325}$ A kardaga (also kardaya, kardaja) appears to have been an observational instrument similar to a quadrant, except that it had an arc of fifteen degrees as opposed to ninety. See Thorndike and Sarton, "Notes and Correspondence," 420-24. The word kardaga appears in medieval astronomical treatises and means a circular arc containing fifteen degrees.

326 "Et ego prefatus Johannes multo affectu desiderans veritatem hujus sensibiliter agnoscere, mihi corde omnia ista conferens et comprehendens, instrumentum ad hoc congruum 15 pedum in semidyametro continens $6^{\mathrm{am}}$ partem quadrantis arcuatam, quod kardaga nominatur, elevavi in linea meridionali super lapidem immobilem rectissime quantum possibile fuit ..." Poulle, "Les tables Alphonsines," 266.
} 
[observational] instrument" in Europe. ${ }^{327}$ Its size would have improved the accuracy of its measurements, which was clearly a priority for Muris. Procuring and mounting this instrument surely required considerable resources.

We might stop short of calling it an ostentatious display, but the sight of Muris and his kardaga would certainly have made an impression. Bearing in mind that it was written two years after the fact, the close of the Expositio paints a picture of a young astronomer confident in his abilities:

And thus I, the aforementioned John, and my quaternions, are bound and will be bound to guarantee for all astronomers and their inheritors the predicted entrances of the sun and the things [here] enclosed, and to defend them against all invidious naysayers, ignorant people, and those who disparage other people's wordsagainst all persons both clerical and lay, before any judge, but particularly before the astrolabe and torquetum, judges which could not be persuaded by entreaty, or swayed by gifts, to keep silent about the truth. ${ }^{328}$

Notice the stress on the astrolabe and torquetum, apparatus used for making direct observations. The value of the Alfonsine tables was their fidelity to observed reality. Muris based his confidence on experience and observation, both his own and his authorities. With an understanding that the very science of astronomy was built upon observation, he praised Alfonso for having assiduously compiled the observations of the

\footnotetext{
${ }^{327}$ Pedersen, "European Observatories," 17. David C. Lindberg reports of a quadrant in the Islamic Maragha Observatory that had a radius of over thirteen feet, built in the second half of the thirteenth century. Beginnings of Western Science, 264.

328 "Et sic ego Johannes prefatus et quaterni mei omnibus astrologis et eorum heredibus predictos introitus solis et inclusa tenemur et tenebimur garantizare et deffendere contra omnes invidos, reprehensores, ignorantes et contempnentes aliorum dicta et quasque personas religiosas et mundanas coram quibuscumque judicibus specialiter astrolabio et turqueto qui pro tacenda veritate nec flecti prece nec obliquari munere dignarentur." Text and translation in Desmond, Music and the moderni, 95. Text also found in Poulle, "Les tables Alphonsines," 268. Desmond observes a striking similarity between this statement and one found at the beginning of the Nine Conclusions, which were appended to the Notitia artis musicae some few years after its completion. Music and the moderni, 95.
} 
ancients. ${ }^{329}$ In the opening lines of a short treatise on the daily positions of the sun, also from 1321, Muris explicitly ascribed his confidence in the Alfonsine tables to verification through observation: "Let it be known to all present and future astronomers that as far as truth is concerned the tables by the illustrious prince Alfonso, king of Castile, are the most precise among those that address planetary motions, when checked against experience by means of visible eclipses and conjunctions." ${ }^{1330}$ With his enormous kardaga, Muris proved the lengths he would go to verify that fidelity.

However critical first-hand experience was in the determination of truth, Muris understood that it was only a starting point. The usefulness of an observation and its resulting data was dependent on its being written down: "In those sciences of which the whole lies in experience (which having been proved once, henceforward a similar [experience] will not return), we cannot believe learned authors except according to that which is written in their codices. In these, immutable observations of things are stored, as it were, in the treasury of wisdom. ${ }^{1331}$ Muris recognized that in order to be of use to future astronomers, it was necessary for him to record the results of his observations. Considering the high praise he bestowed on Alfonso, king of Castile, ${ }^{332}$ as well as his

\footnotetext{
329 "Ymaginationibus eorum ac antiquorum observationibus undique deductis subtiliter et collatis fecit illud opus generale, sumptis etiam benedictis et erroribus extirpatis, per quod quidem opus optime inveniuntur loca planetarum verissime in omnibus temporibus sibi datis." Poulle, "Les tables Alphonsines," 250. 330 "Notum sit omnibus astronomis presentibus et futuris quod ex veritate tabularum alfoncii principis illustris regis castelle que sunt inter ceteras de planetarum motibus veriores, cum per eclipses et coniuncciones sensibiles experiencia probet eas." Text and translation in Chabás and Goldstein, "John of Murs Revisited," 411-12.

331 "In illis quorum tota scientia jacet in experiencia que semel experta decetero consimilis non redibit credere non possumus expertis actoribus nisi secundum quod in eorum codicibus scriptum est, in quibus observationes rerum invariabiles sicuti in thesauro sapientie reponuntur." Poulle, "Les tables Alphonsines," 261. I have taken some liberties with this translation in order to clarify its meaning.

332 "Alfonso of Castile, a noble king, distinguished in genius, a man of great ability, excelling all other in the knowledge of the stars, whose imagination embraces the entire celestial sphere with its motions, a man free from falsehood, privy to the truth, in his desire to bring those who were stuttering about planetary
} 
insistence on presenting the treasury of Alfonso's tables to the world, ${ }^{333}$ Muris stands before us as a man acutely aware of the efficacy of texts and their power to impart prestige. In the next chapter we will see how he harnessed the power of text to advance not just the art of music but also his own reputation.

motions back to the path of truth and to extirpate errors." From the Expositio; quoted in Desmond, Music and the moderni, 92.

333 "But we were unwilling to let such great knowledge stay hidden from learned men, and so in the aforementioned work we will earnestly endeavor, to the best of our ability, to expound the intention of the aforementioned king." Ibid. 


\section{Chapter Four}

\section{The Notitia artis musicae}

Before we begin our analysis of the text of the Notitia artis musicae, one more point of context needs to be examined. In his dissertation, "Music in the Arts Faculty of Paris in the Thirteenth and Early Fourteenth Centuries," Gilles Rico describes a unique questio, or "academic question," that opens a rare window into the scholarly attitude toward musica mensurabilis in the first quarter of the fourteenth century. ${ }^{334}$ The question compares the two sides of music that Muris was interested in: (1) the quadrivial subject, as found in Boethius's De institutione musica, that deals with the mathematical theory of ratios, and (2) the singing of polyphony, the knowledge of which, according to the questio, is passed down from singer to singer. The question then asks which is nobler and superior. It may come as no surprise that the anonymous author rules resoundingly in favor of the Boethian science. Curiously, he describes the two parts of music in parallel terms: 'proportion and quantity of sound according to high and low' and 'quantity and proportion of sound according to long and short.' That is, harmony and rhythm (in modern terms) share certain constituent parts, namely quantity and proportion. The difference lies in the way these elements are known.

\footnotetext{
${ }^{334}$ The questio was a central feature of the scholastic method. Originating with lectures on specific academic themes, the questio developed into its own literary form. Its structure was reflective of the scholastic disputation: the question was submitted, both sides were argued, and finally a determination was made. Questiones literature is quite diverse and ranges from the relatively straightforward to the extrememly complex. See Grant, Foundations of Modern Science, 40-41 and 127-31. The manuscript containing this question (ms. D-EF CA $4^{\circ} 369$, fols. 125v-126r) is held at Universitätsbibliothek Erfurt. For Rico's description of the Sammelcodex, or "collective codex"; its contents; and its two musical questions, see "Music in the Arts Faculty," 189 and 190-92. For the question under discussion, see ibid., 206-12. In this discussion, I draw from both Rico's analysis and the untranslated transcriptions of portions of the questio that he gives in his footnotes.
} 
The author draws from Aristotle's De anima, Metaphysica, and Analytica posteriora to determine that music in the sense of singing notes of various lengths is purely practical; determines simply that (quia) the notes work this or that way as learned through experience and sensation; measures by sense perception; and brings about sensual delight. The musica of Boethius, on the other hand, is speculative; determines why (propter quid) consonances work the way they do by means of reason; measures by the most certain proportions of numbers; brings about comprehension; and is useful for the total good and for the perfection of the intellect.

Paired with the understanding that university education was concerned with determining underlying causes and made no room for the teaching of polyphonic practice, the perspective maintained in this questio can be taken as fairly representative of the general scholarly attitude toward musica mensurabilis. As Johannes de Muris addressed many of its themes in the Notitia, the perspective presented in this questio serves as an appropriate context in which to understand the role they play in his approach to his subject.

Like the author of this questio, Muris showed an interest in 'ways of knowing' and recognized the inherent superiority of knowledge based on reason. He started his treatise with an account of his philosophy of ways of knowing; that is, he outlined his epistemological stance. It will be shown that although this stance is essentially Aristotelian, Muris shifted Aristotle's focus and augmented it with Ptolemy's concept of generational advancement based on new observation. With this in mind, the outline Muris presented at the opening of the Notitia will serve as our guide as we work our way 
through the treatise, where he applied his epistemology to the whole of music, both theoretical and practical. After this brief prologue, the rest of Book I is given to a summary of the first two books of De institutione musica of Boethius. Muris presented this source material in terms resonant with contemporary scholastic discourse in such a way as to support his rational approach to practical music in Book II. Crucially, he established in Book I the precedent for mathematically analyzing musical sounds, each understood as a succession of motions. We will see how this corresponds with Ptolemy's ontology, thus clearing the way for Muris to apply the astronomical method for organizing time to the temporal measurement of musical sounds. This analysis will shed new light on the way Muris framed and understood his own contribution, and it will demonstrate a Ptolemaic influence on Muris's approach to musical reasoning.

\section{Book I - "Prologus"}

The prologue or opening remarks in a text often reveal the intentions of the author and serve as the key to understanding the text. This was no less the case in the Middle Ages as it is today. In the first section of the Notitia (titled "Prologus" by Ulrich Michels), ${ }^{335}$ which is a clever recasting of a passage from the first book of Aristotle's Metaphysics, Muris enlisted the "prince of philosophers" to highlight the necessity of experience for the development of any art. ${ }^{336}$ Quoting one of Aristotle's early

\footnotetext{
${ }^{335}$ Michels justifies this interpolation by pointing out that the subject of this section is distinct from the theoretical material that follows. In fact, "the subdivision of the Notitia into chapters does not seem to have been the work of Muris." Michels, Notitia, 44.

${ }^{336}$ The following analysis owes much to Diergarten, "'Experiments' in Fourteenth-Century Musical Thought." I do not, however, rely on his analysis; like a good scientist, I have reproduced his 'experiments' in order to confirm their results. Additionally, Diergarten makes no mention of a Ptolemaic influence on the Notitia. See pp. 31-32 for my description of Diergarten's chapter.
} 
conclusions, Muris's opening line reads: "The prince of philosophers, Aristotle, says in the introduction to his Metaphysics: 'Without qualification, the sign of a knowledgeable man is the ability to teach."'337 Muris then zigzagged his way backwards through Aristotle's argument to set up his own conclusion. We can understand the thrust of Aristotle's argument when we consider that it is establishing the preeminence of metaphysics (the science of being) on the basis that it is the furthest from the practical arts, as we can see from this summary from the commentary of Thomas Aquinas:

From what has been said he proves his major thesis, that is to say, that wisdom deals with the causes of things. ... This is evident from the foregoing; for the more a man attains to a knowledge of the cause, the wiser he is. This is also evident from the foregoing; because the man of experience is wiser than one who has sensation alone without experience; and the artist is wiser than any man of experience; and among artists the architect is wiser than the manual laborer. And similarly among the arts and sciences the speculative are more scientific than the practical. ... It follows, then, that that science which is wisdom in an absolute sense is concerned with the causes of things. ${ }^{338}$

Aristotle contended that "science and art come to men through experience," because it is through experience of singulars that we are able to form knowledge of universals. ${ }^{339}$ And although 'men of experience' often do better in practical matters than those with theory but no experience, artists are wiser because they grasp the universals whereas men of experience do not. This is Aristotle's familiar hierarchical principle that universals are built on singulars, and that the further one moves away from singulars (and utility) toward the universals and the understanding of principles, the wiser that person is.

\footnotetext{
337 "Princeps philosophorum Aristoteles ait in prooemio Metaphysicae suae: Omnino scientis signum est posse docere." Michels, Notitia, 47. "Et omnino signum scientis est posse docere." From the thirteenthcentury translation by William of Moerbeke included in Aquinatis, Metaphysicorum Aristotelis, 5. (Hereafter, Metaphysicorum.) $981^{\mathrm{b}} 7$.

${ }_{338}$ Aristotle and Aquinas, Commentary on the Metaphysics, 39.

339 "Hominibus autem scientia et ars per experientiam evenit." Metaphysicorum, 5. 981ª 4.
} 
While not denying the superiority of the understanding of universals, Muris turned this argument on its head in order to emphasize the importance of singulars. Building his argument (roughly) in the reverse, Muris, as we have seen, started from the principle that a knowledgeable man can teach. This is because the artist knows the wherefore of a thing (propter quid), that is, why it is the way it is and how it works, whereas men of experience only know the thing itself (quia). ${ }^{340}$ "For that reason," he wrote, "we suppose that masters of an art are wiser than men of experience (expertis). And on account of this, we consider art, more than practical experience (experimento), to be knowledge (scientiam)." 341 But then he went yet further back in Aristotle's argument and paraphrased: "Nevertheless, insofar as art is of the universal, and experience (experimentum), on the other hand, of the singular, the universal presupposes the singular, therefore art presupposes experience." ${ }^{342}$ Approached from this direction, Muris has shown that experience and singulars are the very base on which universals, and therefore art, are built. He then went on to state this more explicitly: "Experience indeed has brought about art, and we see men of experience make more headway than those who

\footnotetext{
340 "Experti enim ipsum quia sciunt, sed propter quid desciunt." Michels, Notitia, 47. "Experti quidem enim ipsum sciunt quia, sed propter quid, et causam congoscunt." Metaphysicorum, 5. 981 a 29-31.

341 "Ideoque artifices expertis sapientiores esse opinamur. Et ob hoc artem magis experimento scientiam esse existimamus." Michels, Notitia, 48. "Artifices expertis sapientores esse opinamur. . . Et ob hoc magis artem experimento scientam esse existimamus." Metaphysicorum, 5. 981 a $25-26$ and $981^{\text {b }}$ 8-9.

342 "Quoniam tamen ars est universalium, experimentum vero singularium, universalia praesupponunt singularia, igitur ars experientiam praesupponit." Michels, Notitia, 48. Diergarten calls the second half of this sentence "Muris's own contribution .... And this new premise ... is a quite distinct statement in the so-called Universalienstreit, the 'problem of universals."' "'Experiments' in Fourteenth-Century Musical Thought," 50. I see it, rather, as a clever rewording of this passage from earlier in the Metaphysics:

"'Experience made art,' as Polus says. . . Now, art comes into being when from many conceptions acquired by experience a single universal judgment is formed about the similar things." Aristotle and Aquinas, Commentary on the Metaphysics, 25. 981ª 4-6.
} 
have 'reason without experience."' 343 Here Muris has combined two separate statements from the Metaphysics. Further, he has taken them out of context. There is no indication that in the Metaphysics, these ideas come out of a discussion of medicine and the need for physicians to heal "Socrates or Callias, or some individual" not Man. ${ }^{344}$ For Aristotle, it is in specifically practical matters that men of experience often do better than those with theory but no experience. In Muris's context, Aristotle seems to be expressing the idea that although the propter quid is superior, it is built upon and requires the quia. It is at this point that Muris struck out on his own, but still cautiously. "Therefore, it is necessary in every single art to have first a theory, [and then] a corresponding practice, so that the thing which was known in the universal can be applied to the singular." ${ }^{134}$ In this line, Muris did more than reinforce the Aristotelian preeminence of theory over practice; he also asserted that good practice must follow the lead of wise theory, implying that theory is useful to practice. ${ }^{346}$ "But," Muris's second conclusion states, "since every art is derived from experience (experimentis), it is proper for every single master of an art first to take pains regarding the experiential (experimentam) side of art." ${ }^{347}$ Although at first glance, these two conclusions seem to contradict each other, when taken together we can

\footnotetext{
343 "Experientia quidem fecit artem et expertos magis proficere videmus 'rationem sine experientia' habentibus." Michels, Notitia, 48. "Sed expertos magis proficere videmus, sine experientia rationem habentibus." Metaphysicorum, 5. 981 a 14-15.

${ }^{344}$ Aristotle and Aquinas, Commentary on the Metaphysics, 25.

345 "Igitur necessarium est in unaquaque arte habere primo theoricam, practicam convenienter, ut illud, quod scitum est in universali, ad singulare valeat applicari." Michels, Notitia, 48.

${ }^{346}$ In the introduction to the Metaphysics, Aristotle describes a hierarchy in which the utility of knowledge is inversely proportional to wisdom. He does not express that universal knowledge applies to the singular. Although in the Nicomachean Ethics, he does say that "art . . is a state concerned with making, involving a true course of reason." Aristotle, Basic Works, 1025. 1140 20-21.

347 "Sed cum omnis ars ex experimentis dependeat, oportet unumquemque artificem primo circa artis experimentam laborare." Michels, Notitia, 48.
} 
see that Muris was claiming a reciprocal relationship between theory and practice. An art is built on the accumulation of experiences, but the singulars that arise out of those experiences need to be understood rationally and processed into universals, the resulting theory of which can in turn govern the practice of the art.

There is nothing anti-Aristotelian about the epistemology outlined above; in fact, we have seen that it was drawn directly from Aristotle's Metaphysics. What Muris has done is shift the focus. With Aristotle, singulars are the fundamental building blocks in a heirarchy that moves from utility to pure speculation. Muris, on the other hand, always kept one foot on the ground. Astronomy and music, his two main interests - under the umbrella of mathematics — were both inseparably coupled to observable experience. In these fields, theory's only value was in the fidelity with which it described the phenomena. In the introduction to the Almagest, Ptolemy recognized that improvements to a science are made generationally, each improving on the last: "It is this love of the contemplation of the eternal and unchanging which we constantly strive to increase, by studying those parts of these sciences which have already been mastered by those who approached them in a genuine spirit of enquiry, and by ourselves attempting to contribute as much advancement as has been made possible by the addititional time between those people and ourselves." ${ }^{348}$ Observing that the notational system of the previous generation was insufficient to the task of accurately describing contemporary music, Muris set out to improve it, with the goal of maximum fidelity. At the end of Book II, after revealing the

\footnotetext{
${ }^{348}$ Toomer, Ptolemy's Almagest, 37.
} 
art of music, Muris stated that anything capable of being sung can also be written down. ${ }^{349}$

As composers experimented with new ideas and techniques in the first decades of the fourteenth century, they were, from the perspective of Muris's 'prologue,' accumulating experiences related to the art of measured music. Those experiences were crucial building blocks in the advancement of that art. What was needed was a musicus to understand rationally the accumulation of singulars and discover the principles underlying them. Muris felt himself to be the man for the job. As his introductory statement claimed, "the sign of a knowledgable man is the ability to teach." Muris has claimed this role for himself.

At the end of his 'prologue,' Muris stated his intentions for writing the Notitia and his reasoning behind its structure: "We, however, for the sake of the general good and for reasons of showing the truth, which long lay hidden, propose to be vigilant about revealing the art of music, setting about to elucidate two things about it in a concise manner: first the theoretical, second the practical, to which it is not unsuitable that, in a certain way, some theory be connected." ${ }^{350}$ Muris has packed a lot into this one sentence. First, observe the language he used to describe what he will be doing in the Notitia. He will be "showing the truth, which long lay hidden," and "revealing the art of music." Muris did not see himself as fabricating new ideas; like a good 'scientist,' his goal was to

\footnotetext{
349 "Quoniam sicut contingit ex ore proferre, sic possibile est notare, dum vox sit integra sive recta." Michels, Notitia, 84.

350 "Nos autem propter bonum commune et ratione veritatis, quae diu latuit, ostendendae circa artem musicae proponimus vigilare, intendentes circa eam duo breviter enodare: primo theoricam, secundo practicam, cui non est inconveniens, quodammodo quamdam theoricam implicari." Ibid.
} 
describe things as they actually are. The "truth" was already there, and his task was "to elucidate" it. ${ }^{351}$ Second, Muris's stated intention for doing this was "for the sake of the general good and ... showing the truth." The author of the questio, discussed earlier, holds similar qualities to be the purview of the speculative sciences alone. ${ }^{352}$ Muris has extended the usefulness of the study of music to the whole of music, theoretical and practical. And as an art, he will be treating both with "a true course of reason." ${ }^{353}$ Last, what we will find in the theoretical portion (Book I) will, "in a certain way," be brought to bear on the discussion of the practical (Book II).

Before entering our discussion of the complex and shifting relationship that theoretical (or speculative) music and practical music maintained in the Middle Ages, it may be advisable to make a few remarks concerning terminology. In the literature, both contemporary and modern, the terms 'theoretical music' and 'speculative music' have been used more or less interchangeably to refer to the medieval treatment of music as the mathematical discipline of quantity related to quantity, or ratio. Speculative, however, can also be used adjectivally to describe the reasoned method of treating a topic. In this way, we may speak of Muris's speculative approach to practical music. The word theory is equally equivocal. In addition to the usage defined above, it can also be used more generally, e.g., mensural theory. Further confusion may arise from the modern sense of

\footnotetext{
351 "Enodare," rendered here as "elucidate," litterally means "to loosen, untie." Muris's job as a musicus was to untie the knot of the art of music, making its nature comprehensible.

352 "Sed scire aliquam scientiam vere speculativam licet ad nihil aliud sit utile nisi ad totum bonum quod talis est perfectio intellectus." Quoted in Rico, "Music in the Arts Faculty," 208. Muris's "showing the truth" is hardly less 'noble' than "the perfection of the intellect."

${ }^{353}$ See n. 346.
} 
music theory, which includes analyses of consonances and intervalic relationships - as in medieval music theory, though decidedly less mathematical and geared toward practical ends - and rhythms and their notation — subjects that fell under the purview of musica mensurabilis in the Middle Ages.

Traditionally, speculative music was concerned with mathematical truths only incidentally connected with physical phenomena. But the relationship was always somewhat blurred. Although its focus was mathematical, Boethius's De institutione musica dealt with practical musical issues such as note names, tetrachord theory, modes, and consonances. But a distinction resided in his attitude about the understanding of these topics as opposed to their application. ${ }^{354}$ In book I, chapter 34, Boethius explained that there are three classes of musician: "The first class consists of those who perform on instruments, the second of those who compose songs, and the third of those who judge instrumental performance and song." The third class, he continues, "since it is totally grounded in reason and thought, will rightly be esteemed as musical. That person is a musician (musicus) who exhibits the faculty of forming judgments according to speculation or reason relative and appropriate to music concerning modes and rhythms, the genera of songs, [and] consonances," etc. ${ }^{355}$ Boethius indeed had a very low opinion

\footnotetext{
354 "With respect to Boethius, Guido says, his book is not useful to singers, but only to philosophers, because it deals principally with theoretical music, or if it touches on practical music, it touches on it only in a theoretical way." This is from the Speculum musicae of Jacobus referring to Guido of Arezzo. Quoted in Desmond, "Behind the Mirror," 320. The reference comes from Guido's Epistola de ignoto cantu: ". . . Boetium ... cuius liber non cantoribus, sed solis philosophis utilis est." Quoted in Gushee, "Questions of Genre," 408, n. 129.

355 Boethius, Fundamentals of Music, 51. "Unum genus est quod instrumentis agitur, aliud fingit carmina, tertium quod instrumentorum opus carmenque dijudicat. ... Tertium est quod judicandi peritiam sumit, ut rhythmos cantilenasque eorumque carmen possit perpendere. Quod scilicet quando totum in ratione ac speculatione positum est, hoc proprie musicae deputabitur. Isque musicus est cui adest facultas secundum speculationem rationemve propositam ac musicae convenientem, de modis ac rhythmis, deque generibus
} 
of the other two classes who act as slaves, make no use of reason, are totally lacking in thought, and are led to song by a certain natural instinct. ${ }^{356}$ "How much nobler, then, is the study of music as a rational discipline than as composition and performance!"357

While the distinction between the mechanical (practical) and liberal (speculative) arts persisted into and through the Middle Ages, the derision with which the former was treated abated somewhat in the twelfth and thirteenth centuries. ${ }^{358}$ A small step was taken by Hugh of St. Victor (1096-1141), who incorporated the mechanical arts into his classification of knowledge. This early twelfth-century schema relied on a re-working of Augustine and argued that the mechanical arts were an important component in man's slow climb back to its perfect, pre-fall, state. ${ }^{359}$ Hugh's categorization is quite extraordinary in that he divided knowledge into four groups: theoretical philosophy, practical philosophy, logic, and the mechanical sciences. ${ }^{360}$ Music retained its place within theoretical philosophy as a division of mathematics, though it also made an appearance among the mechanical sciences under theatrica. ${ }^{361}$

By the middle of the thirteenth century, we find in Robert Kilwardby's De ortu scientiarum a classification of knowledge with striking similarities to the conclusions in

cantilenarum, ac de permixtionibus, ac de omnibus de quibus posterius explicandum est, ac de poetarum carminibus, judicandi." Boetii De institutione musica, 224-25.

${ }^{356}$ Ibid.

${ }^{357}$ Boethius, Fundamentals of Music, 50. "Quanto igitur praeclarior est scientia musicae in cognitione rationis, quam in opere efficiendi atque actu tantum, scilicet quantum corpus mente superatur!" Boetii De institutione musica, 224.

358 The following discussion draws heavily on the excellent scholarship of Elspeth Whitney and Joseph Dyer, which treat of (respectively) the place of the mechanical arts and music in medieval classifications of knowledge. Neither source, however, deals with Muris or the Notitia.

${ }^{359}$ Whitney, Paradise Restored, 89-90.

${ }^{360}$ Dyer, "Medieval Classifications," 21.

${ }^{361}$ Ibid., 21 and 25. 
the Notitia's 'prologue,' and possibly its source. Kilwardby, an English Dominican who both studied and taught at the University of Paris, based his classification system on Hugh of St. Victor's but substantially expanded and modified it. He defined music as a "speculative science perfective of the human aspect in the knowledge of sounding harmony or of sounds harmonically congruent according to something of this type," and its end as the knowledge of this for the improvement of the soul. ${ }^{362}$ Though maintaining a speculative and mathematical understanding of music, he also recognized music as something other than pure mathematical abstraction, an audible phenomenon. Kilwardby duplicated the three categories of musician we saw from Boethius, and again it was only the third category, the judge, which required speculation; the other two were categorized as scientie mechanice, though this carried no pejorative connotations. ${ }^{363}$ This is reflective of a general trend in scholastic discourse on the practical arts. ${ }^{364}$ For Kilwardby, Musici mechanici and musici mathematici were distinguished by the intended ends they pursued, which were understood in terms of Aristotle's propter quid/quia dichotomy. ${ }^{365}$ Further, and of considerable significance to this discussion, was Kilwardby's conception of the 'reciprocal relationship' between these two ways of knowing, for he held that the speculative contained an element of the practical, and the practical made use of the speculative: ${ }^{366}$

\footnotetext{
362 "Finis: talium rerum et talis numeri cognitio, sive perfectio partis animae speculativae per cognitionem huismodi. Definitio: scientia speculativa humani aspectus perfectiva cognitione harmoniae sonarae vel sonorum harmonice convenientium secundum quod huismodi." Text and translation in Ibid., 40. ${ }^{363}$ Ibid., 41-42.

364 Thomas Aquinas makes a striking counter-example to this trend, as he refused to acknowledge craft as the practical component of the speculative sciences. Whitney, Paradise Restored, 139-40.

${ }^{365}$ Dyer, "Medieval Classifications," 43.

${ }^{366}$ Whitney, Paradise Restored, 141.
} 
In as much as we have said something separately concerning the speculative part of philosophy and something about the practical part, now it is important to say something about them in comparison with each other. I ask therefore in what way they are distinguished according to their degree of speculative philosophy and praxis, since those which are practical are, indeed, speculative it is important certainly that one consider first by speculative virtue what one ought to perform in practical virtue - and, conversely, the speculative sciences are not without praxis." 367

Like Muris, in his first conclusion in the Notitia's 'prologue,' Kilwardby advocated for first having a "speculative virtue," which one can then apply to practical matters. It is in Muris's second conclusion that we see a slight variance with Kilwardby. Whereas Kilwardby acknowledged the presence of some practice in the realm of speculation, Muris insisted that those seeking theoretical knowledge labor at experience because it is the foundation of universal knowledge. Most of Kilwardby's examples illustrate a more one-directional relationship. The speculative sciences instruct the practical operations: arithmetic teaches how to do calculations; geometry teaches how to make measurements, useful to carpenters and stoneworkers; astronomy teaches how to navigate; and music teaches how to play instruments. ${ }^{368}$ And although he wrote that "the speculative sciences are practical and the practical speculative, ${ }^{1369}$ he is less forceful when presenting the idea that the practical arts provide the raw data that can lead to the advancement of the speculative sciences:

Architecture, construction, and arms-making with respect to their method of operating are under geometry because geometry makes known the propter quid of many things about which they make known only the quia. Similarly, I think that

\footnotetext{
367 "Postquam aliquid de parte philosophiae speculativa et aliquid de parte practica seorsum diximus, nunc oportet de earum ad invicem comparatione aliquid dicere. Quero igitur quomodo distinguantur penes speculationem et praxim, cum illae quae praticae sunt sint etiam speculativae —oportet enim prius virtute speculativa contemplari quod virtute practica debemus operari-et e converso speculativae non sine praxi sunt." Text and translation in ibid., 120-21.

368 Ibid.

369 "Videtur ergo quod et speculativae sint practicae et practicae speculativae." Text and translation in ibid.
} 
wool-making is with respect to its method under arithmetic and geometry. It examines indeed the number and texture of threads and the measurement and form of the warp, affirming in each of these things that it is this way or that way, while the causes of these same things pertain to arithmetic or geometry. ${ }^{370}$

Notice that number and measure sit at the intersection of the practical and speculative.

But the difference still lies in the two ways of understanding number and measure, following the familiar quia/propter quid division. Muris's project in the Notitia was to "reveal" a propter quid understanding of mensural music that took into account the new quia data derived from the experience of contemporary composers, Vitry in particular.

It was in the decades following Kilwardby's composition of De ortu scientiarum that mensural theorists started making the great leaps in the flexibility of their notational systems that we saw in Chapter Three. The opening lines of Franco of Cologne's Ars cantus mensurabilis tell us something of this generation's attitude toward the relationship between music theory and practice:

Since, as they say, certain philosophers (in theory, principally Boethius, in practice, certainly Guido the monk, and, in the greatest detail regarding the church tropes, St Gregory) have sufficiently dealt with plainsong and have adequately illuminated it to us both in theory and in practice, we propose to deal with polyphony (which plainsong precedes as a principal topic precedes its subordinate), answering the prayers of certain highly respected individuals, not perverting the order so very perfectly laid out by the philosophers mentioned above. $^{371}$

\footnotetext{
370 "Similiter architectonica, fabrilis et armatura quoad modum operandi sub geometria sunt, quia ipsa habet dicere propter quid multorum de quibus ipsae dicunt tantum quia. Similiter lanificium quoad modum puto esse sub arithmetica et geometria. Numerum enim et texturam filorum et mensuram telarum et formam considerat dicens in omnibus quia sic est vel sic, cum eorundem causae ad arithmeticam vel geometriam spectent." Text and translation in ibid., 122. For Whitney, this passage shows "how crafts provide empirical knowledge of physical conditions, the causes of which can be explained by the physical sciences." Ibid. 371 "Cum, inquiunt, de plana musica quidam philosophi sufficienter tractaverint ipsamque nobis tam theorice quam practice efficaciter illucidaverint, theorice precipue Boecius, practice vero Guido Monachus, et maxime de tropis ecclesiasticis beatus Gregorius, idcirco nos de mensurabili musica, quam ipsa plana precedit tam quam principalis subaltern am, ad preces quorundam magnatum tractare proponentes non pervertendo ordinem ipsam planam perfectissime a predictis philosophis subponimus propalatam." Text and translation in Scott, "Ars cantus mensurabilis," 88-89.
} 
Franco explicitly recognized the distinction between theory and practice, but he expressed no priority between them. They are both necessary, though in different ways, for the 'illumination' of plainsong, or chant. ${ }^{372}$ Here we can see the shadow of Kilwardby's reciprocal relationship. Significantly, those who have "sufficiently dealt" with both of these aspects of plainsong are referred to as philosophers, which seems to imply some level of speculation. In his treatise, Franco dealt with the new issues of measured notation, which he saw as building upon the work of his predecessors. ${ }^{373} \mathrm{He}$ did not, however, feel the need to revisit their work before delving into the functional issues of his notational system. This approach is consistent with all the major mensural treatises of the second half of the thirteenth century, which covered essentially the same topics and in roughly the same order. ${ }^{374}$

It is reflective of a different set of intentions that with the Notitia artis musicae, Johannes de Muris took a different tack: Whereas Franco's did not cover speculative music, considering it sufficiently treated, Muris divided his treatise into two books, the first of which was dedicated entirely to musica theorica. Furthermore, although the contents of the Notitia's second book, Musica practica ("that part which is

\footnotetext{
${ }^{372}$ Plainsong does not require precise rhythmic measurement. It is necessary for polyphony in order for the various lines of music to line up with each other. Note that Scott's "polyphony" is a rendering of "mensurabili musica." Johannes de Grocheio related the distinction this way: "Others divide music into plain or unmeasured, and measured, understanding by plain or unmeasured the ecclesiastical, which, according to Gregory, is determined by many tones. By measured they understand that which is made out of diverse sounds measured and sounding simultaneously, just as in conducti and motets. But if by unmeasured they understand music not measured in any way but rather uttered completely at will, they are wrong, since any operation of music and of any art ought to be measured by the rules of that art. If by unmeasured they understand not so precisely measured, it is possible that this division seems to remain." Grocheio, Ars musice, 59.

${ }^{373}$ Franco invokes the Aristotelian concept of subalternation whereby one 'science' uses the principles established in another, the understanding of which is not the concern of the subaltern 'science,' e.g., optics to geometry and music to arithmetic.

${ }^{374}$ Scott, "Ars cantus mensurabilis," 81-82.
} 
measurable"), ${ }^{375}$ bear a degree of resemblance to those of the ars antiqua treatises - like its predecessors, the Notitia discusses notational figures, modes, and 'perfect' and 'imperfect' time-Muris dealt with these issues in a cursory and often speculative ${ }^{376}$ way in contrast to the detailed and didactic treatment of Franco and his contemporaries. ${ }^{377}$ As we saw in the 'prologue,' in Muris's epistemology, theory was one half of the reciprocal process of advancing an art, and its inclusion in the Notitia then serves as a base from which new accretions could be added. In developing his wholistic and speculative approach to music, Muris was likely influenced by the Tractutus de musica of Hieronymus de Moravia. The Tractutus presents a comprehensive coverage of musical issues, from definitions and psychological effects to speculative theory to plainsong to mensuration. ${ }^{378}$ In it, speculative and practical music ran together in an unbroken line, mutually governed by the precepts of "scientific inquiry." 379 Once again, Muris was pursuing a different goal than Moravia. The Notitia is a relatively short treatise; Muris was not attempting to cover every aspect of music, but was rather aiming for a

\footnotetext{
375 "Quoniam in antepositis sermonibus theoricam musicae leniter tetigimus et in brevi, nunc quoque de eius practica, ea parte, qua mensurabilis est." Michels, Notitia, 65.

${ }^{376}$ Jan Herlinger observes that "the Notitia is very much the work of a scholar examining the rational bases of a new mensural system rather than a musician showing how it actually works." "Music Theory," 285-86. For the 'speculative' content of Book II of the Notitia, see below, pp. 110-19.

377 "The principal concern of all the major thirteenth-century treatises on polyphony was to impart the descriptions of the notational features that enabled the performance of polyphonic music." Scott, "Ars cantus mensurabilis," 74.

${ }^{378}$ Weber, "Intellectual Currents," 2.

379 "The juxtaposition of passages borrowed from Boethius and John [Cotton] in the prologue of the Tractatus de musica reveals that Jerome does not consider the theoretical and practical branches of music to be distinct from one another. Rather, he intends to put the abstract, conceptual approach found in Boethius's De institutione musica in the service of the practical goals he shares with John. Although Jerome admits lines of inquiry into his treatise on music that Boethius would have denied can be properly considered part of the discipline at all, Jerome's conception of music is essentially Boethian: one ought to aspire to true understanding of music, and this understanding can only be acquired through scientific inquiry. However, Jerome has eliminated the false dichotomy between the theoretical and practical, creating a work in which they are treated as complementary, rather than oppositional, branches of the discipline." Ibid., 87-88.
} 
fundamental understanding of it. That understanding was not possible without addressing both parts of music, theoretical and practical. As "it is necessary in every single art to have first a theory," we will now examine Book I of the Notitia artis musicae and see how Johannes de Muris applied his epistemology to its contents.

\section{Book I - Musica theorica}

Despite the cursory nature of the study of music at the university, an educated contemporary reader would have instantly recognized Book I of the Notitia as a recapitulation of Boethian music theory. But Muris did more than simply summarize Boethius's famous tome. He molded it to fit his needs, and presented it in terms his contemporaries would understand. One result of the thirteenth-century curricular shift from the quadrivium to Aristotle's natural and moral philosophy was that the academic interest in music transferred from the mathematics of consonances to issues of ontology, which grappled with the dual nature of music. ${ }^{380}$ This dual nature was not the theory/practice dichotomy we have been discussing, but rather a related yet distinct issue, that while the principles of music were mathematical and abstract, they resided in sounds, which are physical phenomena. Thus, music had a hybrid nature, part physical (its material object) and part mathematical (its formal object) and was assigned to the category of scientia media. $^{381}$

Significantly, Muris opened his discussion of musica theorica with a definition of music not found in De institutione musica. Instead, he chose one that conformed to the

\footnotetext{
${ }^{380}$ Rico, "Music in the Arts Faculty," 183-84.

381 See Dyer, "Medieval Classifications," 65-69.
} 
contemporary scholastic definition, which recognized music as a scientia media: "Seeing that music is sound related to numbers, or vice versa, it is clearly necessary for musicians to consider both number and sound."1382 An examination compendium for the arts faculty of Paris c.1250, the De communibus artium liberalium, uses this exact wording - though reversed, as Muris indicates - when it asks "whether the subject of music is numbers related to sounds." ${ }^{1383}$ Indeed, this wording was used by Grocheio, where he neatly captured the contemporary understandings of music: "Certain people describe music considering it according to form and material, saying that it is about number related to sounds. Others, considering its operations, say it is an art applied to singing" (my italics). ${ }^{384}$ Numerus relatus ad sonos was also the definition of the subject of music adopted by several of the key theorists of the ars antiqua. ${ }^{385}$ Some scholars, however, insisted that this definition was too general and that in music, number was related to sounds in such a way as to produce consonances and would therefore be ontologically different from number in the way that it is used to count things. ${ }^{386}$

Defining musica as "sound related to numbers" served Muris in two ways. First, its simplicity and ambiguity allowed him, in Book II, to relate numbers to rhythmic duration understood as a component of music. Second, its reference to the dual nature of music perfectly contextualized his subsequent retelling of Boethius's account of the generation of

\footnotetext{
382 "Quoniam musica est de sono relato ad numeros aut econtra, necessarium est musicis, utrumque numerum scilicet et sonum considerare." Michels, Notitia, 49.

383 "Utrum numerus relatus ad sonos sit subjectum in musica." Quoted in Rico, "Music in the Arts Faculty," 40. My translation.

384 "Describunt autem musicam quidam ad formam et materiam considerantes. Dicentes eam esse de numero relato ad sonos. Alii autem ad eius operationem considerantes, dicunt eam artem ad cantandum deputatam." Grocheio, Ars musice, 56-57.

${ }^{385}$ Ibid., 185.

${ }^{386}$ Rico, "Music in the Arts Faculty," 45-46.
} 
sound in terms resonant to his contemporary audience of university-trained music

enthusiasts. This retelling was adapted from De institutione musica, Book I, chapter 3.

Boethius's description of the production of sound is brief enough to quote in its entirety:

Consonance, which governs all setting out of pitches, cannot be made without sound; sound is not produced without some pulsation and percussion; and pulsation and percussion cannot exist by any means unless motion precedes them. If all things were immobile, one thing could not run into another, so one thing should not be moved by another; but if all things remained still and motion was absent, it would be a necessary consequence that no sound would be made. For this reason, sound is defined as a percussion of air remaining undissolved all the way to the hearing. ${ }^{387}$

Here is the corresponding passage in the Notitia, which directly follows the sentence we just saw: "Seeing that music is sound related to numbers, or vice versa, it is clearly necessary for musicians to consider both number and sound."

Now, before anything is numbered, it is necessary for it to exist. Therefore, it is necessary for sound to be produced before being counted. For the generation of sound, three things are required: a striker, a struck thing, and a medium fit to be struck. First, something breaking the air swiftly; second, a naturally sonorous body; third, air broken violently. A stroke is not made without motion, and so neither does sound exist without motion. Sound is therefore the breaking of air from the impact of the thing striking on the thing struck. For it is impossible for a sound to be made when there is only one thing. ${ }^{388}$

\footnotetext{
${ }^{387}$ Boethius, Fundamentals of Music, 11. "Consonantia, quae omnem musicae modulationem regit, praeter sonum fieri non potest. Sonus vero praeter quemdam pulsum percussionemque non redditur. Pulsus vero atque percussio nullo modo esse potest, nisi praecesserit motus. Si enim cuncta sint immobilia, non poterit alterum alteri concurrere, ut alterum impellatur ab altero. Sed cunctis stantibus motuque carentibus, nullum fieri necesse est sonum. Idcirco definitur sonus percussio aeris indissoluta usque ad auditum." Boetii De institutione musica, 189.

388 "Antequam enim aliquid numeratur, oportet ipsum esse. Ideo sonum prius genarari quam numerari necesse est. Ad generationem soni tria necessario requiruntur: percutiens, percussum et medium percutiendi. Primum frangens aerem celeriter, secundum corpus sonabile naturaliter, tertium aer fractus violenter. Ictus non fit sine motu, ergo neque sonus absque motu est. Est igitur sonus fractio aeris ex impulsu percutientis ad percussum. Nam impossibile est, cum sit unum solum, fieri sonum." Michels, Notitia, 49-50.
} 
The first disparity we notice in these two accounts is that Muris shifted the focus from consonances - the phenomenon of two distinct pitches being in concordance with each other in a way that is aurally pleasant — to numbers. Similar to what we saw in the 'prologue,' Muris reversed the order of his source material's argument. Boethius started his discussion with consonance and pitch, noted that they are found in sounds, then established that sounds rely on motion for their generation (literally 'rendering'). Not until somewhat later did he establish the connection between motion and number. Muris started with sound related to number, investigated how sound comes to be, and then recognized the necessity of motion for its existence (his first mention of consonance is still some way off). After this, Muris fairly closely followed Boethius, but these subtle shifts have now oriented the discussion around number and sound's physical generation.

This leads us to the second disparity between the two accounts. Although still quite cursory, Muris's account of the generation of sound is much more detailed than that of Boethius. As with much medieval philosophy, there are layers of transmission here. Boethius's conception of sound was drawn roughly from Aristotle's De anima II.8. Muris adopted the brevity and general shape of Boethius's text while supplementing it with details from De anima. Specifically, Muris took his three requirements for the generation of sound from Aristotle, who wrote that

sound in act is always of something, on something, in something: for it is caused by percussion. Hence it is impossible for anything by itself, as a single thing, to produce sound. For there must be one thing that strikes and another that is struck; hence whatever emits sound does so 'on something,' i.e. by contact with something - which, when touched with a blow, sounds. Moreover, a stroke is not made without motion. . . . Further: sound is heard in air . . . There must be a percussion of solid objects on each other, and on air. This happens if air is confined 
when struck, and cannot disperse. Hence if the striking is rapid and violent sound results. ${ }^{389}$

By referencing these lines in Aristotle, Muris not only called upon the authority of the Philosopher but also further established the physical side of music's dual nature. In relation to the outline in the 'prologue,' at this point he has begun to establish his theory in terms of physical phenomena related to number - the introduction to mathematics will follow. He was then able to proceed with his summary of De insitutione musica in the context of music as a scientia media, laying out the principles of the theory before introducing the other critical element, practice, in this case musical consonances. ${ }^{390}$

Following Boethius, Muris went on to explain how the lowness or highness of a sound is due to the relative density of its motions: ${ }^{391}$ "Of sounds, one is low another is high. The low is that which is produced from slower and more diffuse motion, the high, that which is joined together from more rapid and dense motion." ${ }^{1392}$ Each sound, then, is made up of many motions, but these motions follow one upon the other so closely that we perceive them as one single sound, "just as the color of the uppermost surface of a top set in motion is seen to be a circular line, although it was nothing other than a point." ${ }^{1393}$ This last

\footnotetext{
389 Aristotle and Aquinas, De Anima, 277-78 (slightly modified). "Fit autem qui secundum actum sonus semper alicuis ad aliquid, et in aliquo. Percussio enim est faciens. Unde impossibile est, cum sit unum, fieri sonum. Alterum enim est verberans, et quod verberatur. Quare sonans, ad aliquid soonat. Tangit enim aliquid. Cum autem ictu tangitur, sonat. Ictus autem non fit sine motu. ... Amplius auditur in aere .... oportet solidorum percussionem fieri ad seinvicem [sic] et ad aera. Hoc autem, si permaneat percussus aer, et non disolvatur: unde si velociter et fortier percutiatur, sonat." Aquinas, De Anima Commentarium, 110.

${ }^{390}$ Muris does make one brief mention of consonance in his discussion of principles. See Appendix, p. 151.

${ }^{391}$ This general concept also comes from Aristotle. See De anima II.8 (420 26-420 4$)$.

392 "Sonorum alius gravis alius acutus. Gravis est qui ex tardioribus et rarioribus motibus generatur, acutus vero qui ex velocioribus et spissioribus aggregatur." Michels, Notitia, 50.

393 "Licet in utroque sint plures motus discreti plures sonos numero facientes, ut patet in chordis nervorum impulsis, tamen sine interruptione sensibili audiuntur quasi unus sonus continuus propter velocitatem motuum annexorum, velut color existens in superficie summitatis trochi moti videtur esse linea circularis, licet non fuerit nisi punctus." Michels, Notitia, 50. The analogy of the top comes from De institutione musica, I.3.
} 
concept, which Boethius attributed to Nicomachus, ${ }^{394}$ is critical for the theory of harmonic ratio that follows. ${ }^{395}$ Here Muris begins the march toward mathematics:

A high sound, then, is made out of a low one through the addition of motion; likewise, a low one is made out of a high one through subtraction. Thus in high sounds there are more motions; in low, fewer. Moreover, every paucity is related to a plurality expressed numerically. Therefore, it is necessary for a low sound to be expressed in relation to a high sound by comparing them, just as the number of the motions of one is comparable proportionally to the number of the motions of the other. ${ }^{396}$

Continuing to follow De institutione musica (Book I.3-4), Muris described and

named the various classes of ratio, that is, the ways in which one number can be greater than another. ${ }^{397}$ Although the details of this discussion are not relevant to our present purposes, it is worthwhile to note that he did not directly quote his source. Moving succinctly from point to point, Muris paraphrased, edited, and clarified his leading authority. A critical edit, at this point, is Muris's removal of all but one brief reference to consonances. This section on the classes of proportion is pure, abstract principle. Muris has established sound as a physical phenomenon, the characteristics of which are determined by their constituent quantities of motion. Then he established the principles by which quantities relate to other quantities. He even excluded four chapters of De institutione musica that follow the classification of ratios, which all deal with consonances.

\footnotetext{
${ }^{394}$ De institutione musica, I.31. This idea is not espoused by Aristotle.

${ }^{395}$ This idea gets picked up again in Book II of the Notitia. See below, p. 111-12.

396 "Acutus vero sonus fit ex gravi per additionem motuum, ex acuto quoque gravis per subtractionem. In acutis igitur sonis plures sunt motus, in gravibus pauciores. Omnis autem paucitas ad pluralitatem sub quodam numero refertur. Ergo sonum gravem ad acutum comparando necessarium est referri, sicut numerus motuum unius ad numerum motuum alterius proportionaliter comparatur." Michels, Notitia, 5051. It is important to remember here that at no point is Muris suggesting the literal counting of movements. The "science" of music, inherited from the Greeks and handed down by Boethius, was a mathematics of proportion or ratio, e.g., this sound contains twice as many motions as this sound $(2: 1)$.

${ }^{397}$ See Appendix, p. 151-52.
} 
Considering his focus on the mathematical and physical in Book I of the Notitia, one might be surprised to find that Muris included the famous myth of Pythagoras' discovery of the harmonic proportions. ${ }^{398}$ In this oft-told tale, we meet a Pythagoras who is preoccupied with discovering a way to know the root causes of musical consonances "in accordance with reason." For him, hearing was not reliable enough for the task. As he walked about pondering this problem, he happened by a workshop where men were pounding with hammers. To his amazement, the hammers produced a "wondrous consonance"! ${ }^{399}$ He was compelled to investigate this phenomenon, so he went over to the workshop and had the men exchange hammers with each other to see if the consonance was a result of the men's respective strength. The concordant sounds persisted, leading Pythagoras to observe "that the harmony was contained in the given nature of the hammers." ${ }^{400}$ By investigating the weights of the hammers, he was able to ascertain that

\footnotetext{
${ }^{398}$ This is from De institutione musica, I.10, "Quemadmodum Pythagoras proportiones consonantiarum investigaverit." Boetii De institutione musica, 196. See Appendix, p. 152. Though not Muris's own (see n. 335), some medieval manuscripts title this section "De musicae inventione." Michels, Notitia, 56.

399 "Pythagoras nolens aurium iudicio de consonantiis adhaerere, quoniam sensum quemlibet circa id, quod suum non est, decipi non est mirum — iudicat enim auris sonum, proportionem minime comprehendit-, in anxietate diu manens, qualiter scientiam de consonantiis rationabiliter inveniret, quadam vice praeteriens officinas fabrorum malleos audivit quamdam consonantiam mirabilem emittentes." Ibid. In this extraordinary sentence, we find a rare concordance with the text of De institutione musica. Muris only switches the order of Boethius's "praeteriens fabrorum officinas," "passing the workshop of craftsmen." This is often rendered as "workshop of blacksmiths."

400 "Et statim quasi attonitus ad eos conversus est dubitansque, ne ex viribus hominum melodia proveniret, iussit permixtim malleos transmutari, et idem ut prius sentiens animadverit concinentiam in malleorum natura sic disposita contineri." Ibid.
} 
four of the hammers ${ }^{401}$ were proportionally related such that, in various combinations, they produced (in modern terms) the octave, fifth, fourth, and tone. ${ }^{402}$

Muris could easily have extracted the relevant proportions and given a detailed account of their various combinations and their relationships to musical consonances. In fact, after reciting the story, that is just what he did. ${ }^{403}$ Then why include it? The answer becomes clear in the context of what we saw in the Notitia's 'prologue.' In this story, Muris had a ready-made example of 'experience' leading to the development of a 'science.' After telling of the various methods Pythagoras used to confirm the principle he had discovered, Muris stated that "from these experiments, as they converged in his memory, he grasped one universal, which was for him the principle of art and knowledge (scientia)." ${ }^{404}$ This echoes precisely what Aristotle wrote in the introduction to his Metaphysics: "Now in men, experience comes from memory, for many memories of the same thing produce the capacity of a single experience.... Art comes into being when, from many conceptions acquired by experience a single universal judgement is formed about similar things." ${ }^{405}$ Significantly, the corresponding passage in De institutione musica bears none of this Aristotelian flare. Boethius simply stated that Pythagoras "came to enjoy a most complete

\footnotetext{
${ }^{401}$ Although there were five hammers, one was found to be dissonant and was therefore thrown out. In his book The Fifth Hammer, Daniel Heller-Roazen has used this fifth hammer as a metaphor for exploring the ways in which nature resists neat systematization. This reference is not to be taken as a referral.

402 The weights were $12,9,8$, and 6.12 and 6 have a $2 / 1$ relationship (the octave, C to C), 12 and 9 (and 8 and 6) have a 4/3 relationship (a fourth, $C$ to F), 12 and 8 (and 9 and 6) have a $3 / 2$ relationship (a fifth, $C$ to $\mathrm{G}$ ), and 9 and 8 have a $9 / 8$ relationship (a tone, $C$ to D). Although these principles are critical for understanding of quadrivial musica, they are of no importance for the understanding of this thesis. ${ }^{403}$ See Appendix, pp. 152-53.

404 "Ex quibus experimentis ad memoriam concurrentibus accepit unum universal, quod sibi fuit principium artis et scientiae." Michels, Notitia, 57.

${ }^{405}$ Aristotle and Aquinas, Commentary on the Metaphysics, 25. "Fit autem ex memoria hominibus experimentum. Eiusdem namque rei multae memoriae unius experientiae potentiam faciunt. . . Ars cum ex multis experimentalibus conceptionibus una fit universalis, velut de similibus, acceptio." Metaphysicorum, 5. $981^{\text {a }} 1-3$ and 7-8.
} 
assurance through the various experiments. . . And in this way he found the rule." 406 The emergence of consonances at this point in the treatise also gains significance in light of the 'prologue.' Recall Muris's first conclusion: "It is necessary in every single art to have first a theory, [and then] a corresponding practice, so that the thing which was known in the universal can be applied to the singular." In his retelling of De institutione musica, Muris first established the principles (universals) of proportion to which these discoveries could be applied. "But, since every art is derived from experience (experimentis), it is proper for every single master of an art first to take pains regarding the experiential (experimentam) side of art." Thus, the experiences (and experiments) of Pythagoras played a decisive role in the development of harmonic theory, but only as they were able to be understood through the established theory of proportion. In the next section, Muris went on to synthesize the results of this reciprocal relationship.

In the exposition of harmonic proportions that follows the myth of Pythagoras, Muris no longer dealt with abstract ratio divorced from consonances. Drawing from $D e$ institutione musica I.16-19, he applied proportion theory to the harmonic ratios in order to demonstrate all the proportional relationships involved in the intervals of a musical scale. As with his catalogue of classes of proportions, his explanation is methodical, clear, and concise, leaving out all mathematical detail. He explained how a double octave is made by continuing the proportion that makes the octave, how an octave is made by combining the proportions of a fourth and a fifth, and the like. At the end of this passage, Muris stated that

\footnotetext{
${ }^{406}$ Boethius, Fundamentals of Music, 19. "Integerrimam fidem diversa experientia capiebat. . . Itaque invenit regulam." Boetii De institutione musica, 198. Neither have I found any other retelling of this myth that draws a direct link between Pythagoras' discovery and Aristotelian epistemology.
} 
"a diapason [octave] is composed out of five tones with two semitones. But two semitones do not come together in a perfect tone, as will be demonstrated in the following." ${ }^{n 07}$ At this point, things get complicated.

The following section, which deals with the semitone, amounts to approximately twenty-three percent of the total length of Book I of the Notitia. What might seem to us to be an arcane detail of speculative music theory proves to be of quite some importance to Johannes de Muris. In fact, the issue of the semitone was a critical and difficult 'problem' in the Pythagorean-based theory of Boethius, and extensive portions of De institutione musica are dedicated to it. ${ }^{408}$ It is a testament to the cursory nature of music studies at the University of Paris that it was apparently common in lectures on De institutione musica for the major and minor semitones to be given (incorrectly) the ratios $17: 16$ and $18: 17$, respectively. ${ }^{409}$ This may be enough to account for Muris's own extensive account of the semitone in the Notitia. However, as we have seen, the material in Book I is not merely an abbreviated recapitulation of De institutione musica but rather follows an argumentative strategy to achieve its own goals. It will be helpful to briefly summarize the issue at hand and the contents of this section before considering some possible ulterior motives for its inclusion.

In the Pythagorean harmonic system, the interval of an octave exactly equals the combination of the intervals of a fourth and fifth. This is rather elegant, and the math is

\footnotetext{
407 "Diapason constat ex quinque tonis cum duobus semitoniis. Sed illa duo semitonia ad perfectionem toni non veniunt, ut probabitur in sequenti." Michels, Notitia, 58.

${ }^{408}$ Book I.16-17; II.28-31; and the entirety of III. Because Boethius designed De institutione musica as a pedagogical tool, he introduced the same topic multiple times, quite simply at first and then with increasing complexity. Book III deals with the many subtopics that arise out of the mathematical peculiarity that is the semitone.

${ }^{409}$ Rico, "Music in the Arts Faculty," 35-36 and 48-49.
} 
quite simple. ${ }^{410}$ This simple elegance disappears when fourths and fifths (and therefore octaves) are broken down into their constituent tones. ${ }^{411}$ The interval of a fifth is made up of three tones and a semitone, and the interval of a fourth is made up of two tones and a semitone. Therefore, an octave is made up of five tones and two semitones. But that is not the same as saying that the octave is made up of six tones because, as Muris has indicated, two semitones do not make up a tone. In other words, a semitone is not half of a tone. The result of this is a mathematical quagmire that we will merely dip a toe into. ${ }^{412}$

Muris's treatment of the topic draws from two different discussions in $D e$ institutione musica. ${ }^{413}$ The first is arithmetic and rather simple. Observing that a half of anything will produce a whole when doubled, he showed that when a semitone $(256: 243)$ is doubled, it does not produce the ratio for a tone $(9: 8)$. It is worth noting that although this approach and its basic terms are taken from Boethius, Muris's version is straightforward and unambiguous. On the other hand, as Boethian scholar Calvin Bower points out, the corresponding passage in De institutione musica is "obtuse" and caused some confusion for its medieval readers. ${ }^{414}$

As a mathematician, Muris understood that this arithmetic demonstration did not actually show the doubling of the semitone's ratio because the extension of a proportion occurs exponentially, not linearly. This requires a geometric proof, which he drew from the

\footnotetext{
${ }^{410}$ The ratio for the fourth is $4: 3$, the ratio for the fifth is $3: 2$, and the ratio for the octave is $2: 1$. By combining the ratios of the fourth and fifth, we get $4: 3: 2$. The ratio that encompasses these two is then 4 : 2 , which reduces to $2: 1$, the octave. (Muris, like Boethius, reverses these terms when doing compound ratios of this sort. The reason for this is beyond me.)

${ }^{411}$ The ratio for the tone is $9: 8$.

${ }^{412} \mathrm{I}$ am certain that all readers will agree that even this is quite enough.

${ }^{413}$ De institutione musica, I.17 and II.29.

${ }^{414}$ Boethius, The Fundamentals of Music, 28 n. 93.
} 
more mathematically sophisticated Book II of De institutione musica. This approach involves the calculation of a geometric mean by multiplying the two terms of the semitone's ratio together, then placing the product between the squares of those same two terms. These three terms are now in the proportion of the semitone. If a semitone were truly half a tone, then the outside terms would be in the ratio of a tone. ${ }^{415}$ Of course, they are not.

As Muris's recapitulation of De institutione musica projects through the lens of the quia/propter quid relationship, it arrives at a point where the propter quid explanations cease to be tidy, where the details cease to fit nicely into the overall plan. This happens precisely when Pythagorean ratio theory runs up against an actual musical scale, that is, when the math truly becomes music. Although Muris's long digression into the unequal division of the semitone is sufficiently explained by its prominent position in $D e$ institutione musica, the opportunity for Muris to prove his mathematical prowess, and the need of a corrective for faulty university instruction, it also serves as an excellent lead-in to Book II. ${ }^{416}$ It will be remembered that the ideas in Book II were inspired by the recent

\footnotetext{
${ }^{415} 256^{2}=65,536 ; 243^{2}=59,049 ; 256 \times 243=62,208$; thus $(65,536: 62,208: 59,049) .65,536: 62,208$ and $62,208: 59,049$ are both in the ratio $256: 243$ (a semitone), but $65,536: 59,049$ is not in the ratio $9: 8$ (a tone). If the present reader is finding some difficulty in following these procedures, this likely would have been an amenable reaction for Muris because it puts him, as the author, in the position of a 'possessor of arcane knowledge.' This is enviable for a scholar who depended on his reputation for the acquisition of lucrative employment.

${ }^{416}$ In his treastise on the monochord, Parvus tractatulus de modo monacordum dividendi, Prosdocimo de' Beldomandi mentioned Muris's work on the semitone: "Musica ficta must not be placed midway between the two letters - equidistant from the extremes - so that it would divide the tone into two equal parts because, as has been proven by demonstration by Boethius, Johannes de Muris, and a great many other musical authors, the tone is in no way divisible into two equal parts." Herlinger, Brevis Summula Proportionum, 83. Prosdocimo was a quadrivial scientist active in Padua during the first quarter of the fifteenth century; he also wrote commentaris on Muris's mensural theory, Expositiones tractatus practice cantus mensurabilis Johannis de Muris (1414?) and Tractatus practice cantus mensurabilis (1408). Thorndike referred to these commentaries as well as Prosdocimo's canons for the Alfonsine tables. Magic and Experimental Science, 4:78-79.
} 
developments in musical practice, developments that did not fit neatly into the accepted mensural theory of the day. If the Pythagorean-based theory handed down by Boethius could grapple with as sticky a subject as the semitone, then surely modern mensural theory could be made to accommodate more complex rhythms that included binary meters.

The last three sentences of Book I make an explicit transition from musica theorica to musica practica. They tell of the subsequent innovators (inventores) of music who (despite the peculiarities of the semitone? ${ }^{417}$ advanced the art of music in various ways: through its application on various types of instruments, the development of lettered scales, and the mapping out the relationships between these scales. ${ }^{418}$ After Pythagoras and Boethius, others had stepped in and continued to advance our understanding of music. ${ }^{419}$

So ends Book I, preparing the way for Muris's own insights.

\section{Book II - Musica practica}

Seeing that in the preceding discussion we have touched lightly and in brief on the theory of music, now it remains to investigate more broadly the practice of it, that part through which it is measurable, since various practitioners think about it in diverse ways. ${ }^{420}$

\footnotetext{
${ }^{417}$ The first of these sentences starts with the Latin word "verumtamen," which means "nevertheless" or "but even so" and is used when resuming after a digression.

418 "Verumtamen sequaces inventores musicae eam ordinaverunt variis modis. Alii in instrumentis chordarum, alii in instrumentis calamorum perforatorum, alii in instrumentis ventorum. Quidam vero posteriorum in vocibus ordinatis per manum iuncturas per litteras alphabeti gradibus distinctis factisque mutationibus unius gradus in alterum, prout subiecta descriptio manifestat." Michels, Notitia, 64.

${ }^{419}$ Note that Muris described those who had made contributions to the art of music as inventores, here translated as "innovators." Inventor comes from the Latin verb invenire, meaning "to find." Hence, an inventor is a "finder." Cf. the end of the 'prologue,' where Muris states his intention to "reveal" the art of music, the truth of which had "long lay hidden." See also n. 462.

420 "Quoniam in antepositis sermonibus theoricum musicae leniter tetigimus et in brevi, nunc quoque de eius practica, ea parte, qua mensurabilis est, restat diffusius inquirendum, cum de ipsa diversi diversimode sentiant practicantes." Michels, Notitia, 65.
} 
In the second book of the Notitia, Muris moved from a mathematical description of musical consonances to a mathematical description of musical rhythms. Some way into his discourse - while describing the idiosyncrasies of applying number to the continuum of time-Muris reminded his readers of the similarity of this process with the way number was applied to pitch in Musica speculativa: "Moreover, pitch is per se a natural form joined to quantity per accidens." ${ }^{421}$ That is, just as number is a non-essential attribute of physically generated pitches, so too is number attributed to the reckoning of the time-values of those pitches. Muris's establishment of rhythmic notation on a mathematical foundation relied heavily on the definition of music as sound related to number as well as the understanding, inherent in music's classification as a scientia media, that although music was a mathematical science, its material was physical. As we have seen, Muris highlighted these two concepts in Book I. Also considered a scientia media was astronomy, Muris's primary intellectual project, as it used mathematics to describe the motions of celestial bodies. He recognized distinct similarities between these two subjects that allowed him to adapt an organizational strategy from astronomy to be used in the service of music. Additionally, the very idea that experience could play a valid, even necessary, role in the development of an art or sciencealso important in astronomy, where Muris recognized the value of observation —was given philosophical justification in the 'prologue,' and this relationship was shown to be critical in Pythagoras' discovery of the knowledge of consonances "based on reason." Following the provisos of this process - working from established principles to rationally assess and

\footnotetext{
421 "Vox autem est per se forma naturalis iuncta per accidens quantitati." Michels, Notitia, 69.
} 
integrate new, experience-derived data—Muris was able to validate the practice-based

origins of his new accretion.

Muris began Book II by explicitly building on an idea developed in Book I:

As was shown in Book I, pitch is generated along with motion, considering it is in the class of successive things. For that reason, when it is being made, it exists, but once it has been made, it does not. Succession does not exist without motion. Time inseparably accompanies motion. Therefore, it is necessary that pitch be measured by time. Time is also the measure of motion. But here, time is the measure of pitch that has been extended along with continuous motion. Moreover, the definition of time and of one unit of time is the same..$^{422}$

Having established at the beginning of Book I that a prolonged sound is generated by a group of consecutive motions, the frequency of which establishes its pitch, Muris then used this as a premise on which to demonstrate the relationship between a sounded pitch and time. ${ }^{423}$ In reemphasizing the physical nature of musical sounds, Muris was able to extrapolate that their duration was determined by the continuation of their constituent motions as measured by time. Hieronymus de Moravia's Tractutus de musica here again served as an exemplum. In it, Moravia wrote:

Therefore, harmonious time must in some way be made like natural time. But speaking naturally, succession is not found except in those things that are subject in some way to motion. The before and after create a succession of time. For from time, which we enumerate as before and after in motion, we understand as tempus, which is nothing other than the number of the before and after in motion. ${ }^{424}$

\footnotetext{
422 "Ut in primo 'libro' ostensum est, vox generatur cum motu, cum sit de genere successivorum. Ideo quando fit, est, sed cum facta est, non est. Succession non est sine motu. Tempus inseparabiliter consequitur motum. Igitur vocem necessario oportet tempore mensurari. Est autem tempus mensura motus. Sed hic tempus est mensura vocis prolatae cum motu continuo. Eadem autem diffinitio temporis et unius 'temporis' assignatur." Michels, Notitia, 65-66.

${ }^{423}$ In the description of its production in Book I, Muris used the word sonus for "sound." In Book II, the discussion is now of pitches (voces), musical sounds that relate to each other in numerically established consonances.

${ }^{424}$ Weber, "Intellectual Currents," 388. "Tempus igitur armonicum, tempori naturali debet aliqualiter assimilari. Sed loquendo naturaliter, successio non inuenitur nisi in illis, que sunt aliqualiter motui subiecta. Prius enim et posterius causant temporis successionem. Ex hoc enim, quod numeramus prius et posterius in motu, apprehendimus tempus, quod nichil aliud est quam numerus prioris et posterioris in motu." Moravia, Tractatus de musica, 167. See the historical imagining that opened this thesis.
} 
This line of reasoning invoked the scholastic discourse on the relationship between motion and time. Following Moravia, Muris identified pitch as being in the class of successive things, that is, a res successiva. In contrast to a res permanens, a res successiva was something whose parts did not all exist at the same time. The distinction became important in medieval analyses of the moment of change. ${ }^{425}$ Motion and time — or a period of time - were considered 'successive things,' and things contingent on either motion or time, such as sound, came also to be categorized in this way. ${ }^{426}$ In Book I, Muris observed that "before anything is numbered, it is necessary for it to exist." Sound and pitch, contingent on motion, exist as successive things.

To flesh out the relationship between motion and time, Muris drew upon the most widely read of Aristotle's works on natural philosophy, his Physica ${ }^{427}$ In Book IV, Aristotle dealt with this relationship, writing, among other things, "not only do we measure the movement by the time, but also the time by the movement, because they define each other," and "time is a measure of motion and of being moved." 428 The connection between motion and time was common coin in the later Middle Ages. ${ }^{429}$ When Muris wrote that "time

\footnotetext{
${ }^{425}$ See Strobach, Moment of Change, 86-94.

${ }^{426}$ See Pasnau, "Entia Successiva," especially 374-76, 391-92, and n. 21. In his Quesitiones subtilissime Scoti in metaphysicam Aristotelis (c.1300), Duns Scotus speaks of sound in terms of succession in a discussion on the divisibility of forms: "Since sound, whether in itself it has degrees or not, comes to be in parts of the medium through local motion, it assumes the condition of the form characteristic of local motion. And therefore successively [sound] comes to exist in these [parts]." Scotus, et al., Questions on the Metaphysics, 379.

${ }^{427}$ Weisheipl, "Aristotle's Physics," 522. The other most commonly studied work of Aristotle's natural philosophy was De anima, which Muris quoted in Book I. Ibid.

${ }^{428}$ Aristotle, Basic Works, 294 (220 $15-16$ and 221 $\left.{ }^{\mathrm{a}} 1-2\right)$. "Non solum autem motum tempore, sed motu tempus, ob hoc quod diffiniuntur ad invicem." "Quoniam autem est tempus metrum motus et eius quod movetur." Aristotle, Physica, 179 and 180. Moravia drew from a different passage in the Physics: "For time is just this - number of motion in respect of 'before' and 'after."' Aristotle, Basic Works, 292 (219 b 1-2).

${ }^{429}$ To take one example from theology, here is Thomas Aquinas in a discussion of the eternity of God:

"Again. Those beings alone are measured by time that are moved. For time, as is made clear in Physics IV
} 
inseparably accompanies motion," he was speaking axiomatically; he was stating an accepted principle of physics. While the invocation of the Aristotelian concept of time in music treatises was not original to Muris or even Moravia, ${ }^{430}$ Muris used this connection as a key piece of evidence in the service of a new conceptual framework. Muris has here introduced another toolbox of principles on which to base his own reasoning.

As an astronomer, Muris would have been quite familiar with the contents of this toolbox, for the connection between time and motion sat at the very heart of medieval astronomy. This is neatly observed in the opening line of the Canons for the Alfonsine tables (1327) by John of Saxony: "Time is the measure of the motion of the primum mobile, just as Aristotle ordained in the fourth [book] of the Physics." ${ }^{431}$ It is in Physica IV.12 that Aristotle made this fundamental observation about the nature of time: "Time is not described as fast or slow, but as many or few and as long or short. For as continuous it is long or short and as a number many or few."432 Muris expressed this idea when he said that "of time, one is greater another is lesser: the greater, which has longer motion, the lesser, which has shorter. With all

[11], is 'the number of motion.' But God, as has been proved, is absolutely without motion, and is consequently not measured by time. There is, therefore, no before and after in Him; He does not have being after non-being, nor non-being after being, nor can any succession be found in His being. For none of these characteristics can be understood without time. God, therefore, is without beginning and end, having His whole being at once. In this consists the nature of eternity." Contra gentiles I.15, trans. Anton C. Pegis, https://isidore.co/aquinas/ContraGentiles1.htm\#15.

${ }^{430}$ In his Ars musica (c. 1380), Johannes de Grocheio wrote that "tempus is the measure of motion, both of the first motion and of the primum mobile and of whatever else that follows, just as is investigated carefully by the philosopher." "Est enim tempus mensura motus et est primi motus et primi mobilis et ex consequenti cuislibet alterius prout a philosopho subtiliter perscrutatur" (16.1, 76-77).

431 "Tempus est mensura motus primi mobilis, ut vult Aristoteles quarto Phisicorum." Poulle, Les Tables Alphonsines, 30.

${ }^{432}$ Aristotle, Basic Works, 294 (220 b 1-4). "Manifestum autem est et propter quod tardum quidem et velox non dicitur, multum autem et paucum et breve et longum. Secundum quidem enim quod continuum est, longum et breve, secundum autem quod numerus, multum et paucum." Aristotle, Physica, Translatio Vaticana, 179. 
things being equal, [time] is measured according to this one dimension." 433 This is an important concept if one is to superimpose a number line onto a time line. Muris also highlighted the importance of this brief note on time, while applying to it rhetorical and authoritative weight, by stating it as a textual parallel with another passage in his Musica theorica. Following the description of the generation of sound in Book I, he wrote: "Of sounds, one is low another is high. The low is that which is produced from slower and more diffuse motion, the high, that which is joined together from more rapid and dense motion."434 We will recall that in that passage, Muris was identifying a characteristic of sounds that allowed them to be compared to each other numerically and proportionally. ${ }^{435}$ With this textual parallel in Book II, Muris has identified a characteristic of time that, as we will see, allows its units to be compared to each other numerically and proportionally.

The significance of this observation is revealed in the lines that follow: "These, however, do not differ in respect to species, for [being] greater and lesser does not alter species. Hence it is that the method of knowing them remains the same, nor does knowledge vary from one to another." ${ }^{436}$ As scholars have noticed, this would mark a subtle yet momentous shift in the way time was conceived in relationship to note shapes. ${ }^{437}$ In the mensural theory of Franco of Cologne, each note shape was considered to be its own species.

\footnotetext{
433 "Temporis aliud maius aliud minus: maius, quod motum prolixiorem, minus, quod breviorem habet ceteris eisdem, secundum unam dimensionem metitur." Michels, Notitia, 66 (my italics). For a discussion of Muris's concept of "the continuous dimension of time" and its role in his music theory, see Tanay, Noting Music, Marking Culture, 83-84. For its connection to the late-medieval discourse on the latitude of forms, see ibid., 84-86.

434 "Sonorum alius gravis alius acutus. Gravis est qui ex tardioribus et rarioribus motibus generatur, acutus vero qui ex velocioribus et spissioribus aggregatur." Michels, Notitia, 50 (my italics).

${ }^{435}$ See above, p. 101.

436 "Haec autem specie non differunt, nam maius et minus speciem non variant. Inde est, quod unum modum retinent cognoscendi, nec in hiis scientia variatur." Ibid., 66.

${ }^{437}$ Desmond, Music and the moderni, 185-89; Tanay, Noting Music, Marking Culture, 83-84.
} 
That is, each—a longa, breve, or semibreve — was essentially distinct as opposed to being a quantified part of a whole. Although Franco's system functioned on metrical relationships between the various note shapes, those relationships were limited to a small set of functional interactions. As Dorit Tanay explains, "each species had its own subclasses, but the long and the short did not belong to a larger whole in the same species, which contained both, and which would have made possible a quantitative comparison between them." ${ }^{438}$ As in astronomy, where time was understood to be a single continuum reckoned with discreet numbers, Muris's system was based on "quantitative comparison." By emphasizing the physical nature of sound, he was able to apply the principles of Aristotle's physics to music's temporal component. This opened the door for a quantitative organization of note values, and Muris designed his organizational system around the one he was accustomed to using in astronomy.

In Book IV of the Physica, Aristotle also described the way in which time functioned as a measure of motion: "... it measures the motion by determining a motion which will measure exactly the whole motion, as the cubit does the length by determining an amount which will measure out the whole." ${ }^{439}$ As an astronomer, Muris was accustomed to using time to track the movement of celestial bodies. This required the selection of a unit of time with which to make the measurement, "as the cubit does the length." Because of their frequent and regular repetition, days were the obvious choice of medieval astronomers for the

${ }^{438}$ Ibid., 36.

${ }^{439}$ Aristotle, The Basic Works of Aristotle, 294 (Physica IV.12, 221 ${ }^{\mathrm{a}} 1-3$ ). ". . . autem ipsum motum in determinando quendam motum aut mensurabit totum, sicut longitudinem cubitum in determinando aliquam magnitudinem que remetietur totum." Aristotle, Physica, 180. 
basic unit of measure for the quantity of time ${ }^{440}$ To increase the efficiency and fidelity of their predictions, astronomers both multiplied and divided the day into equal parts to arrive at greater and lesser units. ${ }^{441}$ The number by which the day was multiplied and divided, however, was somewhat arbitrary and chosen for convenience. Some astronomers employed a base-thirty system (e.g., the producers of the Castilian Alfonsine tables), whereas others chose base-sixty (e.g., the producers of the Parisian Alfonsine tables). ${ }^{442}$ We can return to Chapter One of John of Saxony's Canons for the Alfonsine tables for an explanation of how this works: "Days are called 'firsts,' and 60 firsts make one 'second,' and 60 seconds [make] one 'third,' and 60 thirds [make] one 'fourth."' 443 He did not go beyond fourths because, as he explained, they go up to 36,000 years, which was apparently sufficient. ${ }^{444}$ The process also goes the other direction: one day is divided into sixty minutes, and one minute is divided into sixty seconds, etc. ${ }^{445}$ All units in the astronomical system of time measurement were proportionally related based on multiplication and division and assigned discrete numbers to the continuum of time.

\footnotetext{
${ }^{440}$ As the length of a day varies throughout the year (true solar day), astronomers used a calculation to describe the difference between it and a mean solar day, which is consistent throughout the year. See Chabás and Goldstein, "Equation of Time," 37-41. Cf. Aristotle, Physica IV.12 (220 12-14): "Further, as a movement can be one and the same again and again, so too can time, e.g. a year or a spring or an autumn." Aristotle, Basic Works, 294.

441 "Simili modo procedimus in tempore, incipiendo a diebus tanquam ab integris, et duplici via incedimus sicut jam dictum est in gradibus, scilicet colligendo et frangendo." Poulle, Les Tables Alphonsines, 31.

${ }^{442}$ The Parisians chose 60 because the signs of the zodiac are designated by 60 degrees. This effectively cut out one extra calculation, making their astronomical tables easier to use. "The sexagesimal system: This was taken over by the Greeks (one may guess by the Hellensistic astronomers) from the Babylonians as a convenient way of expressing fractions and (to a lesser extent) large numbers, and of performing calculations with them. It is the first place-value system in history." Toomer, Ptolemy's Almagest, 6. 443 "Dicitur ergo breviter quod dies vocantur prima, et 60 prima faciunt unum secundum, et 60 secunda unum tertium, et 60 tertia unum quartum." Poulle, Les Tables Alphonsines, 32.

444 "Et ultra quarta non procedimus nunc quia non indigemus: essent enim plusquam 36,000 anni antequam 60 quarta complerentur." Ibid.

445 "Et dividimus dies in 60 partes equales quas vocamus minuta dierum, et quodlibet minutum in 60 secunda, et sic semper." Ibid.
} 
Muris retooled this system, with its mathematical regularity, to meet the needs of his notational system, which likewise measured movement with time. Instead of using basethirty or sixty, however, Muris chose a number established by his predecessors in mensural theory: "But in every time which measures pitch, prior scholars have rationally ascribed a certain mode of perfection, positing that time is such that it can undergo division by threes, supposing that every perfection is in the ternary." ${ }^{446}$ Muris further supported the adoption of a base-three system in a long, analogical argument for the perfection of the number three. ${ }^{447}$ The astronomical model for the division of time, however, required a retrofit because of one distinct difference between the measurement of celestial movements and that of musical sounds: the movement of celestial bodies continues unceasingly whereas musical sounds are fleeting.

Muris observed that pitch measured by time was composed of two forms, the natural and mathematical. Although time is mathematically divisible into infinity, natural forms necessarily have limits. ${ }^{448}$ As he said of a pitch at the beginning of Book II, "when it is being made, it exists, but once it has been made, it does not." ${ }^{449} \mathrm{~A}$ measured pitch can only be so short before it becomes inaudible and can only be so long before it can no longer be

\footnotetext{
446 "In omni vero tempore vocem mensurante quemdam modum perfectionis priores rationabiliter assignaverunt, illud tempus tale ponentes, quod per ternarium posset suscipere sectionem, opinantes in ternatio omnem esse perfectionem." Michels, Notitia, 66.

${ }^{447}$ Ibid., 67-68.

448 "Quoniam ergo vox tempore mensurata unionem duarum formarum, naturalis scilicet et mathematicae, comprehendit, licet quod ratione alterius fractio non cessaret, tamen propter aliam vocis divisionem necessarium est alicubi terminari. Nam sicut omnium natura constantium positus est terminus et ratio magnitudinis et augmenti sic parvitatis et diminuti. De monstrant enim naturales, quod natura ad maximum et minimum terminatur." Michels, Notitia, 69. Muris wrote of these physical limitations in 'scientific' terms borrowed from Aristotle, and Dorit Tanay has found similarities in the language and concepts used by Muris to quantify discrete pitches against the continuum of time to the work of other fourteenth-century scholars, who used mathematics to analyze motion. Tanay, Noting Music, Marking Culture, 88-94. For Muris's use of technical language, see Desmond, Music and the moderni, 106. ${ }^{449}$ See n. 422.
} 
sustained. ${ }^{450}$ Muris set himself to understanding those limits: "Therefore, it is proper that it [a sounded note] have boundaries of division the breadth of which no divisible pitch however great its division can exceed. Moreover, we want to understand these boundaries through reason." 451

When Pythagoras set out to discover knowledge about consonance in accordance with reason, he was seeking out a mathematical explanation. In astronomy, Ptolemy used mathematics to understand the motion of heavenly bodies through time. In his ontology, motion and time (along with shape, number, size, and place) were mathematical objects, and "only mathematics can provide sure and unshakeable knowledge to its devotees." 452 It was then quite natural for Muris, who was versed in Pythagorean music theory and Ptolemaic astronomy, to use mathematics to describe musical time. When Muris wrote that he wanted to understand through reason the boundaries of division of a pitch, he meant that he wanted

\footnotetext{
${ }^{450}$ Elsewhere, Muris reinforced the physical properties of pitch with one more nod to De institutione musica (I.14). "Prolonged pitch measured by definite time" does not resemble a point, line, or surface, but is formed in the air like a sphere. This is easily observed by a group of people all standing around the source of the sound. And since the strike that generates a pitch is finite, so too is the pitch, which cannot be generated either in an instant or into infinity. "Vox prolata certo tempore mensurata non solum se facit in aere secundum punctum aut lineam vel superficiem, sed corporaliter et sphaerice, ad instar sphaerae ut lumen in diaphano, quod patet per sex aures dispositas secundum sex differentias positionis. Cumque vox illa sit generata ex virtute impellentis, quae finita est cum a finito procedat corpore, oportet eam habere suae durationis vel continuationis terminos, cum neque in infinitum neque in instanti vox valeat generari." Michels, Notitia, 71. Boethius likened the spread of sound to the waves caused by dropping a stone in water. "In the same way, then, when air that is struck creates sound, it affects other air nearby and in this way sets in motion a circular wave of air; and so it is diffused and reaches the hearing of all standing around at the same time." Boethius, Fundamentals of Music, 21. Cf. Aristotle, Sense and Sensibilia, Ch. 6 (446 20 - 446 27$)$, and pseudo-Aristotle, Problems, XI.6 (899 23-899 17$)$.

451 "Vox autem est per se forma naturalis iuncta per accidens quantitati. Igitur oportet eam habere terminos fractionis, quorum latitudinem nulla vox quantacumque frangibilis valeat praeterire. Hos autem terminos volumus comprehendere ratione." Ibid., 69.

${ }^{452}$ Toomer, Ptolemy's Almagest, 36. In the introduction to his Almagest, Ptolemy wrote: "That division [of theoretical philosophy] which determines the nature involved in forms and motion from place to place, and which serves to investigate shape, number, size, and place, time and suchlike, one may define as 'mathematics."' Ibid.
} 
to understand them mathematically, as that would provide "sure and unshakeable

knowledge."

Having already established the principle that time was divisible by threes, he took three as his base unit and multiplied it by three, three times. So, Muris reasoned, from one, which is one-third part of three and the smallest unit, up to eighty-one mark the minimum and maximum temporal limits of any given musical sound. ${ }^{453}$ He then organized this span of time into four degrees, just as with the astronomical system. Beginning with the smallest part, which he called a minima, up to three makes the fourth degree. ${ }^{454}$ Three minimae equal one brevissima. One brevissima up to three makes the third degree. Three brevissimae equal one brevis. One brevis up to three makes the second degree. Three breves equal one longa. One longa up to three makes the first degree.

\footnotetext{
${ }^{453}$ Muris arrived at these numbers in two ways: $3 \times 3=9,9 \times 9=81 ; 3 \times 3=9,9 \times 3=27,27 \times 3=81$. "Musica igitur a numero ternario sumit ortum, qui ternarius in se ductus novem generat, sub quo novenario quodammodo omnis numerus continetur, cum ultra novem semper fiat reditus ad unitatem. Ergo musica novenarium numerum non transcendit. Qui si iterum in se ducatur, 81 producit, qui productus a ternario disiunctione triplici mensuratur ad modum vocis. Nam ter ter tria ter: ter tria novies productaque trium per tria semper ducta, sicut ter tria producunt novem, ter novem 27 , ter 27 semper generant 81 . Ab unitate igitur, quae tertia pars est ternarii qui perfectus est, usque ad 81 , qui similiter est perfectus, dicuntur esse termini de maximo ad minimum cuislibet vocis, totaque eius longitudo inter hos terminos est inclusa." Michels, Notitia, 72.

${ }^{454}$ Dorit Tanay has stated that Muris took his name for the smallest unit of musical time, the minima, from Aristotle's De caelo. Tanay, Noting Music, Marking Culture, 90 . This is a likely possibility, but we might also consider Augustine's De musica for the term's origin. In Book II, Chapter 3, the master in the dialogue says, "Don't you think we should begin by comparing syllables with each other and seeing by what numbers they are related to each other, just as we have already done with movements in a very long discussion? For all that sounds is in movement, and syllables are certainly sound.... Therefore, when syllables are compared with each other, movements containing numbers found by measure of the length of time are compared with each other... Then the ancients were not absurd in calling one time a sort of minimum interval, proper to the short syllable" (my emphasis). Augustine, On Music, 209-10. The Latin here is, of course, minimum. Muris used the adjective substantively and chose the feminine rather than neuter.
} 
Table 2 Muris's gradus system

\begin{tabular}{|c|c|c|c|c|c|}
\hline Note shape & $\begin{array}{l}\text { Ratio within } \\
\text { degree }\end{array}$ & $\begin{array}{l}\text { Value in } \\
\text { minimae }\end{array}$ & Note name & & Degree \\
\hline & 3 & 81 & longissima & & \\
\hline & 2 & 54 & longior & & first degree \\
\hline & 1 & 27 & longa & 1 & \\
\hline & 3 & 27 & perfecta & / same & \\
\hline & 2 & 18 & imperfecta & & second degree \\
\hline & 1 & 9 & brevis & 1 & \\
\hline & 3 & 9 & brevis & / same & \\
\hline & 2 & 6 & brevior & & third degree \\
\hline & 1 & 3 & brevissima & 1 & \\
\hline & 3 & 3 & parva & / same & \\
\hline & 2 & 2 & minor & & fourth degree \\
\hline & 1 & 1 & minima & & \\
\hline
\end{tabular}

Adapted from Michels, Notitia, 79.

Each degree, then, relates to the next degree up in a three to one ratio, and each note can be reduced to its constituent minimae. In this system, Muris also included the "imperfect," that is to say, all of the twos. Table 1 shows the four degrees, their constituent note shapes, the ratio of each note within its degree, and the total value of each note in minimae. ${ }^{455}$

The similarity between Muris's gradus system and the organization of time in astronomy has not been previously recognized. Dorit Tanay explains this system in terms

\footnotetext{
${ }^{455}$ This is a reproduction, with added labels and translation, of the table included in the Notitia artis musicae. Cf. Table 1, p. 67.
} 
of the concept of the latitude of forms "which allows [for] qualities to be contracted in different degrees of intensities and which calls for a mathematical analysis of intensification or remission by addition or subtraction of parts of the quality in question." 456 It is not my intention to claim that these two precedents are mutually exclusive. It would be a mistake to assume a single influence on any historical decision. Tanay also cites a passage from John Tewkesbury's Quatour principalia musicae (1351), in which he states: "It must be said that if there are minutes or seconds, there are several, namely two or three or four or more, and if there are several, they fall into the category of number, and thus, as numbers, they must begin from unity. But these minutes, which proceed from the imagination, do not pertain to music but to astronomy."157 This seems to confirm that Muris's contemporaries understood that he applied astronomical methods to his mensural theory. Tanay, however, does not draw this connection. Karen Desmond calls attention to an alchemical work by English astronomer and music theorist Walter Odington (fl. c. 1280-1316), in which he assigned four numerical degrees to the intensities of qualities. ${ }^{458}$ She does not go the further step in connecting Odington's or Muris's astronomical background to their four-grade systems.

These astronomers understood that a mathematical system can be manipulated in myriad ways once the rules for the system have been laid out. For Muris, this allowed for a dramatic increase in the flexibility of the existing system. All the rules that previously governed the Franconian notation still applied to Muris's, and they were also expanded to

\footnotetext{
${ }^{456}$ Tanay, "Jean de Meur's Musical Theory," 25. See also Tanay, Noting Music, Marking Culture, 84-92.

${ }^{457}$ Ibid., 120.

${ }^{458}$ Desmond, Music and the moderni, 108.
} 
accommodate rhythmic combinations not previously attempted. ${ }^{459}$ Whereas before, a breve could imperfect a longa, now a longa could be imperfected by a semibreve or even a minima ${ }^{460}$ Once the timeline was reconceived as a numberline, a wealth of new rhythmic combinations became plausible. Furthermore, Muris's gradus system was even more flexible than the description above indicates. What we see in the table is the 'perfect' system, that is, each degree is built upon a one to three ratio. However, there is reason to believe that Muris intended the entire system to be convertible between basetwo and base-three at each degree. In that case, a longa could be worth two breves, a brevis could be worth two brevissime, and a brevissima could be worth two minimae. This is, in fact, how the system came to be used. ${ }^{461}$ Considering that one of the primary innovations of Muris's contemporaries was the use of binary meters, Muris's epistemology demanded that his speculative exposition of musica mensurabilis account for these developments. On the other hand, he was a young man at the beginning of his career, and it would not serve him well to offend the more conservative generation. Therefore, he approached the issue with caution. In a rather cryptic statement early in Book II, Muris explicitly stated his intention to explain this 'invention':

And on this account [that every perfection is in the ternary], they [the ancients] have posited a perfect time for the measurement of song, knowing that in art it is not fitting that anything imperfect be found, although certain moderns believe that they have found [invented] something opposed to this, [but] this is not the case; their intention will be more clearly explained in the following. ${ }^{462}$

\footnotetext{
${ }^{459}$ See Tanay, Noting Music, Marking Culture, 91.

${ }^{460}$ See ibid., 131-45, for an in-depth discussion of the mathmatical and philosophical context of the relation between a whole and its parts as well as its musico-theoretical ramifications.

${ }^{461}$ For a good, succinct description of this that highlights its mathematical aspect, see Taruskin, Music from the Earliest Notations, 248-52.

462 "Et propter hoc tempus perfectum pro mensura cantus cuiuslibet posuerunt, scientes quod in arte imperfectum non convenit reperiri, quamvis huius oppositum aliqui moderni, quod abest, se crederunt invenisse; quorum intentio clarius in sequentibus exponetur." Michels, Notitia, 66 (my italics). Note here
} 
Dorit Tanay has pointed out that "these lines conceal more than they actually disclose."463

Although they read as an indictment of the moderns, it is likely a clever set-up for his reframing of the idea of perfection. Let me suggest an alternative reading: "Accepting that it is not fitting for anything imperfect to be found in art, what the moderns have found is not opposed to this, although they believe it to be so." Rather than tacitly accept 'imperfect' meters, Muris expanded the idea of perfection. ${ }^{464}$

After affirming the perfection of three and noting the disrepute of two for falling short of perfection, ${ }^{465}$ Muris went on to propose that numbers made by combining-that is, multiplying - two and three could also be considered perfect. ${ }^{466}$ For Muris, this concept emerged from the understanding that musical sounds were measured along a continuum of time, which could be divided by three as many times as you would like, into infinity. ${ }^{467}$ At the end of Book II, he explained this idea in more detail. Three consecutive binary notes can together be considered perfect because they are numerically

\footnotetext{
Muris's word choice. The "moderns" are said to believe that they "invented" or "found" (invenisse) a new musical idea (their understanding of which is not correct). At the end of Book I, he referred to those who had advanced the art of music (himself, it is implied, presently included) as "inventors" or "finders" (inventores). Cf. n. 419, above.

${ }^{463}$ Tanay, Noting Music, Marking Culture, 95.

${ }^{464}$ See ibid., 95-99. It is in this discussion that Tanay draws her closest connection between Muris's astronomical experience and his mensural theory. In Muris's proposal of a "continuity" between perfect and imperfect, she sees a reflection of geometric procedures, developed in the mid-thirteenth century, that "emphasized comparisons and equations between different types of motion" and were of interest to astronomers. Ibid., 97-99.

465 "Cum igitur ternarius omnibus se ingerat quodammodo, hunc esse perfectum non debet amplius dubitari Per cuius oppositum, cum ab ipso recedat binarius, relinquitur imperfectus, cum etiam binarius numerus sit infamis." Michels, Notitia, 68-69.

466 "Sed unum compositus sic quilibet numerus convenientiaque, quam habet ad ternarium, perfectum potest merito reputari." Ibid., 69.

467 "Est enim unum, cum sit continuum, non solum iterum in ternarios sed in infinitum partibilis incessanter." Ibid.
} 
equipollent to two ternary notes. ${ }^{468}$ There is no distinction between the two sets from the perspective of physical time, which is a continuum and infinitely divisible. All combinations with note values divisible by six work this way: "That is, three binaries and two ternaries are made equal in $6,12,18,24$ and thus by adding six." 469 He then went a step further and claimed that songs can be written using groups of three notes, each worth three, and groups of two notes, each worth two. ${ }^{470}$ Ostensibly, as long as the final minima count was divisible by three, the song could be considered to adhere to the perfection of the ternary. Latent in these comments is that there is a way of creating a note with a stand-alone value of two units. A convertible, base-two/three system would allow for just that. The concept of equipollence outlined above demonstrates that Muris had done more than simply assign numbers to the units of musical time; he manipulated them mathematically.

Having looked at Muris's reconception of perfection, we can return to the 'moderns.' In light of what we know of Muris's ideas about the advancement of an art from the 'prologue,' we see that these composers, through their experience with polyphonic music, had arrived at a certain quia knowledge, the use of binary rhythms. But they lacked a propter quid understanding of what they had discovered and therefore got it wrong. Their 'invention' was not grounded in principles or based on reason. Muris has taken on the role of musicus, the knowledgeable man with the ability to teach; he has

\footnotetext{
468 "Sunt autem tres binarii perfecti de 'tempore' imperfecto, sed duo ternarii imperfecti de perfecto, et ad invicem revolvuntur et aequa proportione finaliter adaequantur." Ibid., 84. Dorit Tanay discusses this concept at some length in Noting Music, Marking Culture, 95-101.

469 "Adaequantur enim tres binarii et duo ternarii in 6, 12, 18, 24 et sic addendo 6." Michels, Notitia, 84.

470 "Et ex perfectis de perfecto et imperfectis de imperfecto sicut convenit decantatur." Ibid.
} 
taken the data derived from experience, analyzed them against a set of established principles, and incorporated them into his theory. He produced a propter quid understanding of binary rhythms.

\section{$\underline{\text { Conclusion }}$}

In his 'prologue,' Johannes de Muris provided the key to understanding the Notitia artis musicae. These opening remarks described the relationship between theory and practice that leads to the advancement of an art. We have seen this relationship reflected not only in the overall structure of the treatise, but also within both of the books. Muris established principles in the first book—-sound is produced by a succession of motions - that he then brought to bear on the second. Within Book I, mathematical principles are first established and then brought to bear on musical consonances. Within Book II, physical principles are brought to bear on musical notation. And in each, new source data is reconciled with the established principles—Pythagoras' experiments with consonant sound in Book I and composers' use of binary meters in Book II. In both books, the chosen tool for analysis is mathematics, first attributed to motion and then, by extension, to time. In the first case, this was commonly accepted, even praised. In the second, the parallels Muris drew with Book I made this application tenable. He was also influenced by Ptolemy, who counted time among the mathematical objects, an ontological classification that Muris had been utilizing since his first celestial observation some nine years earlier.

As this analysis has shown, when Muris undertook to establish musical time on a mathematical foundation, he received aid from the astronomical method for organizing time, an application made almost intuitive by its inherent similarity with Franco's metric system of 
musical perfection. This mathematical organizational strategy served to normalize and systematize the existing Franconian system. The shift from Franco's metric and qualitative foundation to a mathematical one opened the system up to a wealth of new functionality, allowing a level of rhythmic subtlety as yet unattempted. Muris's new, mathematical, version of the old system had the ability to represent reality with a much higher degree of fidelity, which was also a major concern of his astronomical work. Another such concern was to present complex functions in an easy to use format, a trait also apparent in the Notitia. Normalizing his notational system made it easy to use because the same rules applied to each of the four grades, which was only nominally the case before. Muris also presented his ideas in terms relevant to and broadly understood by the average university student or graduate, presumably his target audience. Those same concepts served as inspiration and source of his mensural theory, which was built upon commonly held principles. ${ }^{471}$

This chapter has demonstrated one other Ptolemaic theme that served to tie the Notitia's two books together: we might somewhat anachronistically call it "scientific progress." In Book I, Pythagoras famously discovered the rational basis of musical consonance. At the book's end, Muris gave a list of the various ways subsequent innovators (finders) had developed the understanding of music. ${ }^{472}$ In Book II, Muris "revealed" the art of music. And at that book's end, Muris explicitly stated that the process of musical discovery

\footnotetext{
${ }^{471}$ In this analysis, I did not explore the semiotic discussions found in Book II, as they have been sufficiently covered by Dorit Tanay and Karen Desmond. Suffice to say that Muris employed relevant contemporary scholastic concepts in this portion of the Notitia as well. See Tanay, Noting Music, Marking Culture, 54-63, esp. 56-61, where she sees deficiencies in Muris's application of language theory to his music theory. Desmond analyzes the relevance of medieval discussions on form and matter to Muris's conception of musical notes. Music and the moderni, 175-76. She also addresses Muris's treatment of the relationship between graphic shapes and musical things in the Conclusions, which are outside the purview of this thesis. Ibid., 176-79.

${ }^{472}$ Michels, Notitia, 64. See Appendix, p. 154.
} 
would continue: "There are, moreover, many other new things latent in music which will appear altogether plausible to posterity." ${ }^{173}$

With the Notitia artis musicae, Johannes de Muris produced a rational, mathematically-grounded account of mensural theory that was an extension of Beothius's speculative music. In the composition of this authoritative text, Muris presented himself a wise and learned musicus and an expert mathematician.

${ }^{473}$ Strunk, Source Readings, 158. "Sunt autem mulae aliae novitates in musica latentes, quae posteris bene dubitantibus apperebunt." Michels, Notitia, 84. 


\section{Chapter Five}

\section{Conclusion}

Johannes de Muris was born in a Europe that was already starting to slip down the far side of the zenith of the thirteenth-century boom years, with their cooperative weather, bumper crops, and surging population and economy. There was no way for him to have known that a century of calamity lay ahead. He was raised in a fully monetized society in which that money was unstable, suffering repeated devaluation. A Norman of some means, proud of his homeland and his intellectual inheritance, he ventured to Paris, Europe's biggest city and the jewel of its intellectual and musical world, to get his education and take his place in a long line of prestigious Norman astronomers. He started developing his mathematical and astronomical skills from the very start, learning to track the movement of heavenly bodies. He learned the language of number, abstracting from time's continuous flow discrete units that could be manipulated in myriad ways to calculate future realities from known quantities. The mathematical precision in which he learned to revel was never purely abstract, for it was a critical tool used in the service of describing the observable cosmos.

As a student at the University of Paris, Muris was introduced to the Aristotelian world with its comprehensive approach to understanding the natural world, the mind, and the very nature of revealing truth. While he studied the extensive Aristotelian corpus and learned its methods, he continued to develop his mathematical and astronomical skills, which provided their own analytical method. As his peers contented themselves with 
learning the rudiments of arithmetic and perhaps dabbled in astronomy, Muris belonged to a small—would he have said elite? — group of specialists, and his confidence grew.

A couple of years into his studies, the weather took a disastrous turn. As the terrible rain and biting winters persisted, there came food shortages, and with them, disease. Muris saw suffering all around him. He also saw the value of his livres plummet. He was fortunate enough not to be among the poor, whose situation was desperate, but these were difficult times, nonetheless. One bright spot, however, remained in these bitter years: music. Despite the pouring rain or falling snow, Muris could look forward to enjoying the company of musicians and fellow music enthusiasts with whom he would bear witness to the stimulating new songs being written and performed. He had always loved music, and this music must have been particularly enjoyable for its architectural structure, which recommended itself to a mathematical mind. Perhaps best of all, it provided food for thought, engaging conversations, and problems to solve.

Muris appreciated music not only as a sonic delight but also as a mathematical science. Like astronomy, theoretical music abstracted numbers from physical movements. These numbers could be compared to each other in various ways to reveal truths about the musical sounds he heard. The numbers unlocked doors to the understanding of why musical sounds fit together the way they did. At some point, he learned of a fascinating musical text held at the library of the Sorbonne and started making trips there to collect the treasure held in its pages. The Tractatus de musica of Hieronymus de Moravia had a special appeal, for it dealt with both the mathematical theory of music and the practical concerns of the polyphony Muris had been enjoying in Paris, taking the two sides as parts 
of a whole. Equally enticing was the fact that it presented music within an Aristotelian framework, bringing the worldview heard in the lecture hall to bear on the sounds heard in the invigorating musical gatherings he had been attending. One of Moravia's Aristotelian explanations of a principle of polyphony in particular was to be of momentous occasion for Muris. Moravia described musical time in the same terms as physical time, as a measure of motion. Here Muris had found a direct link between astronomy and polyphony: they were both built on the same foundational element, the relationship between time and motion.

That music and astronomy shared similarities was not big news; after all, they were both considered scientia media. But the connection recognized by the scholastics was between astronomy and theoretical music, the quadrivial subject taught at the university. The academic attitude toward practical music was one of general scorn as it dealt only in singulars and shared none of the mathematical certainty of theoretical music. Indeed, mensural theory, although conceived in Aristotelian terms, was put together ad hoc to meet the demands of an ever-shifting practice, and the musical debates that raged in Muris's university years were a result, to a large extent, of mensural theory's lack of a stable theoretical base. The connection between polyphony and astronomy that he found in Moravia's Tractatus allowed Muris to apply his mathematical skills to the formulation of a speculative foundation for practical music.

The way that astronomers abstracted numbers to signify the time measurement of celestial motion provided a model for Muris, who abstracted numbers to signify the time measurement of musical sounds. He exploited latent similarities between astronomy's 
place-value system and Franco's note relationships to expand, normalize, and mathematize them. The result was that Muris's notational schema shared astronomy's systemization, organization, and precision, which elegantly answered the needs of his musical contemporaries.

Given Muris's mathematical perspective and the fact that he was not a musician himself - and therefore able to think in terms outside the current notational paradigmhis approach to fixing the ambiguity and inconsistency of the Franconian system might have seemed quite obvious to him. ${ }^{474}$ A major characteristic of Muris's new conceptual framework is that all of its component parts already existed as known, accepted ideas. It can be thought of as a brilliant work of synthesis — brilliant in the way that Muris assembled the constituent ideas to reconceptualize mensural notation. In Boethius's De institutione musica, sounds are a product of motions, and the mathematics of musica theorica describe the relationships between those motions. Muris would highlight these principles, reflecting the current epistemological understanding of music taught in the university, which was grounded in Aristotle's De anima. Likewise, the relationship between motion and time was a well-known tenet of Aristotle's Physica. Even the connection between an Aristotelian understanding of motion/time and the mensural concept of tempus, so central to Muris's theory, was, as we have seen, gleaned from Moravia. Muris adopted from astronomy the use of mathematics to temporally describe motion, a procedure so basic to that discipline that it was sure to be familiar to the

\footnotetext{
${ }^{474}$ Franco's system was quite brilliant and handily met the needs of contemporary composers. By Muris's time, however, composers' needs had pressed into areas not served by Franco's theory. It also remained the base of Muris's system, thus the verb "fix" as opposed to "supplant" or the like.
} 
average university arts student. It should be stressed that the application of number to musical rhythm went back as far as Augustine, but the use of number found in Augustine and the mensural theory of Franco was metrical; Muris's was mathematical.

How long all this had been simmering in Muris's mind is unknown, but at the age of about twenty-four and after four years in a city hit hard by weather, famine, pestilence, and inflation, he escaped to Évreux. It may well have been there that Muris undertook to put these thoughts to paper and wrote the Notitia artis musicae. He appreciated that an idea, however useful, had little value until it was written down. For a written idea to be accepted, it had to be backed by authority and presented in terms that its readers would understand. The premises outlined above greatly aided the acceptance of the new conceptualization of mensural theory in the Notitia. That we see none of the scholastic subtly characteristic of medieval philosophy in Muris's writing indicates that he assumed that each concept was prevalent enough to be presented discursively to support his idea. He was revealing the speculative foundations of practical music, not entering a debate. Muris wrote like a scientist, ignoring any subsidiary issue not directly germane to his thesis. Perhaps because of this axiomatic and direct approach, some scholars have mischaracterized the Notitia as being "intended for younger students at the elementary level," failing to see these traits as elements of a rhetorical strategy, as I have argued. ${ }^{475} \mathrm{~A}$ hallmark of Muris's later writing is a concern with presenting complex material in a way that was easy to understand and simple to use, and we already see this tendency in the

\footnotetext{
${ }^{475}$ Tanay, Noting Music, Marking Culture, 2. This quote comes from Tanay's historiography, where she is citing the work of Max Haas (whose work I have not consulted). Consequently, it is unclear if she shares this opinion. It is difficult for me to imagine what an elementary student could glean about the practical application of notational principles from the Notitia.
} 
Notitia. Muris's theory did not require a wholesale adoption of a new system but rather normalized and expanded the existing one while retaining its basic functions. Likewise, the mathematics he introduced to mensural theory would not have been difficult for his readers, who would have had a basic training in numeracy at the very least. Shifting the notational system to a mathematical basis was a means to provide it with clarity and consistency, not to add unnecessary complexity.

Although not requiring of its readers any expertise in mathematics, Muris certainly thought of the Notitia artis musicae as a mathematical work. That he considered his work in mensural theory as yet another feather in his mathematical cap is made clear in this passage from his Canones tabule tabularum:

And in the very same year [1321] there became clear to us the knowledge of the art of producing and notating music both mensurable and plain, in every possible manner of descanting, not only through whole [notes] but right down to the smallest fractions, along with the most perfect demonstration of the knowledge of squaring the circle, and the exposition of the tables of Alfonso, king of Castile, and the genealogy of astronomy. ${ }^{476}$

In this list—which reads like an addition to his CV—-Muris's achievements in "the knowledge of the art of producing and notating music" sit comfortably beside those of geometry and astronomy. ${ }^{477}$ As the first treatise he is known to have written, the Notitia established Muris as an ingenious mathematical thinker. Although as a university-trained cleric Muris would enjoy the same career prospects as the rest of his peers, at the time he

\footnotetext{
476 "Eodemque anno notitia artis musice proferende figurande tam mensurabilis quam plane ad omnem modum possibilem discantandi non solum per integra sed usque ad minutissimas fractiones, cognitioque ciruli quadrature perfectissime demonstrata, expositioque tabularum Alphonsi regis castelle ac genealogia astronomie nobis clariut." Text and translation in Desmond, Music and the moderni, 86. Although this was written two years after Muris (likely) wrote the Notitia, any intervening developments of his mensural theory would have been built upon that seminal work.

${ }^{477}$ Note the pride in the detailed precision: "ad minutissimas fractiones."
} 
wrote the Notitia he was working hard to establish himself as a specialist in mathematics and astronomy, which provided opportunities of their own. His success in accessing those opportunities would have hinged not only on his connections with seats of power and wealth but also on his personal reputation and renown. For a man seeking a career that rested in large part on a reputation of mathematical expertise and ingenuity, it would certainly have served Muris well to have his name attached to the solution to his generation's most pressing musical problems, particularly the solution he had devised. One opportunity for potentially lucrative employment, particularly as conditions in Europe worsened, was the practice of astrology. ${ }^{478}$ Considering that astrology was susceptible to the accusation of charlatanism (or worse), confirmed mathematical and astronomical skills would have done much to assuage suspicion in this regard. ${ }^{479}$ Muris actively worked to match his quadrivial prowess with that of self-promotion; his writings are strewn with self-confident assertions. In the opening line of the Notitia, he established himself as a wise man, knowledgeable in the why of music — both theoretical and practical—and capable of making that knowledge clear to his readers. ${ }^{480}$ Muris's observation in Évreux attests not only to his zeal for accuracy but also his desire to make that accuracy known. For all the intellectual fodder the Notitia has to offer the historian,

\footnotetext{
${ }^{478}$ Muris's interest in astrology is confirmed by the contents of his library and the discovery of his many annotations in astrological texts as well as two extant prognostications which he wrote. For astrological works in Muris's library, see Miolo, "Jean des Murs's Library," 27-28. For a list of manuscripts containing Muris's annotations, five of which deal with astrological topics, see Desmond, Music and the moderni, 81, Table 3.1.

${ }^{479}$ Hilary M. Carey has described the precarious position of medieval astrologers. While astrologers were increasingly employed in fourteenth-century courts, they were also often accused of witchcraft and political intrigue. See Courting Disaster, esp. 17-19.

480 "The prince of philosophers, Aristotle, says in the introduction to his Metaphysics: Without qualification, the sign of a knowledgeable man is the ability to teach." See n. 337 for the Latin text.
} 
we must remember that it was one step in a man's career, and that for him, it served a practical end in addition to an intellectual one.

This thesis has shown that Johannes de Muris believed in the advancement of human knowledge. The universe contained many hidden truths that the human mind could still uncover. For Muris there was a prescribed path to increasing the fidelity with which the arts and sciences described reality and revealed truth. Each generation inherited a set of principles, known truths, from those who came before. These principles formed the rational basis on which new experiences could be understood. When new information or insights were discovered through experience, they were then subjected to a course of reasoning based on the existing principles. If this process was successful, then the new information became a principle of its own, and the whole system shifted slightly to accommodate the new truth. Thus, through a process of accretion, human knowledge became increasingly precise. As we have seen, this epistemological stance was based on Aristotle's, although Muris added emphasis to the new accumulation of sense data. At the same time, however, Muris did not derive his principles from Aristotelian sources alone. He also relied on the methods of Ptolemaic astronomy, which used mathematics to analyze observable phenomena, a connection that has not been previously recognized.

In this perspective on the Notitia artis musicae, we see a kind of cross-pollination in which an integrated Aristotelian understanding of the natural world was enriched with the precision of Ptolemaic methods. Muris's mensural theory was a product of his understanding of the way the world worked and the most efficient way he knew how to describe it. We cannot 
separate his theory from the Aristotelian and Ptolemaic influences from which it sprang. We cannot accept Christopher Page's "Aristotelian complexion" without robbing Muris of his worldview. For Dorit Tanay's "anti-Aristotelian," we should consider substituting "Ptolemaic." Nor can we accept Gilles Rico's "ad hoc additions to justify certain theoretical choices,” for without those "Aristotelian concepts," Muris could never have arrived at his epochal solution.

In this thesis I have shown the crucial role of Book I - Musica theorica for understanding Johannes de Muris's intentions in the Notitia artis musicae. Far from being "some kind of conventional requirement," it establishes the relationship between theory and practice that is central to Muris's epistemology and the conceptual framework of the Notitia. Further, Muris successfully justified his use of mathematics for the measurement of musical time in Book II by demonstrating its equivalence to the Pythagorean application of mathematics to harmonious sounds as described in Book I. I have also established that in addition to this justification, the function of Muris's epistemology was influenced by his experience in astronomy. Ptolemaic ontology encouraged the application of mathematics to the analysis of time, which was a tenet of Book II - Musica practica. Further, I have drawn a concrete connection between astronomy and Muris's mathematical conception of musical notation. Muris modeled his gradus system, a major innovation in fourteenth-century mensural theory, on the place-value system used in astronomy to organize time mathematically.

As Europe slowly became more inclined to describe the natural world in mathematical terms, it was individuals like Johannes de Muris, responding to an assortment of pressures and motivations and transferring methodologies, who turned the gears of change. 
Bibliography

\section{PRIMARY SOURCES:}

Anicius Manlius Severinus Boethius. Fundamentals of Music. Translated, with introduction by Calvin M. Bower. New Haven: Yale University Press, 1989.

Aquinatis, Sancti Thomae. In Aristotelis Librum De Anima Commentarium. Edited by Angelo M. Pirotta, 4th ed. Turin: Marietti, 1959.

—. In Duodecim Libros Metaphysicorum Aristotelis Expositio. Edited by M.R. Cathala and Raymundi M. Spiazzi. Turin: Marietti, 1964.

Aristotle. The Basic Works of Aristotle. Edited by Richard McKeon. New York: The Modern Library, 2001.

- Aristoteles Latinus 7/2, Physica, Translatio Vaticana. Edited by Augustinus Mansion. Rev. ed. Leiden: E.J. Brill, 1990.

Aristotle and Thomas Aquinas. De Anima, in the Version of William of Moerbeke: And the Commentary of St. Thomas Aquinas. Translated by Kenelm Foster. New Haven: Yale University Press, 1959.

-. Commentary on the Metaphysics of Aristotle. Translated by John Patrick Rowan. Library of Living Catholic Thought. Chicago: Henry Regnery, 1961.

Augustine. On Music. In The Immortality of the Soul; The Magnitude of the Soul; On Music, The Advantage of Believing; on Faith in Things Unseen. Translated by Robert Catesby Taliaferro, 151-379. The Fathers of the Church 4. Washington, D.C.: Catholic University of America Press, 1947.

Boetii De institutione musica libri quinque. Edited by Godofredus Friedlein, 177-371. Leipzig: B. G. Teubner, 1867. [Electronic version prepared by Calvin M. Bower, Luminita Florea Aluas, Penelope Mathiesen, and Thomas J. Mathiesen for the Thesaurus Musicarum Latinarum, 1991.] http://www.chmtl.indiana.edu/tml/6th-8th/BOEMUS1

Grocheio, Johannes de. Ars musice. Edited and translated by Constant J. Mews, John N. Crossley, Catherine Jeffreys, Leigh McKinnon, and Carol J. Williams. Kalamazoo: Medieval Institute Publications, 2011.

Herlinger, Jan W., and Prosdocimo de' Belomandi. Brevis summula proportionum quantum ad musicam pertinet; and Parvus tractatulus de modo monacordum 
dividendi $=$ A Short Summary of Ratios Insofar as They Pertain to Music; and A Little Treatise on the Method of Dividing the Monochord. Greek and Latin Music Theory 4. Lincoln, Neb.: University of Nebraska Press, 1987.

McKinnon, James, ed. Strunk's Source Readings in Music History. Vol. 2, The Early Christian Period and the Latin Middle Ages. Revised and edited by Leo Treitler. New York: W. W. Norton, 1998. [First published in 1950 as Source Readings in Music History. Selected and annotated by Oliver Strunk.]

Michels, Hans Ulrich, ed. Johannes de Muris Notitia artis musicae, et Compendium musicae practicae. Petrus de Sancto Dionysio Tractutus de musica. Corpus Scriptorum de Musica 17. N.p.: American Institute of Musicology, 1972.

Moravia, Hieronymi de. Tractatus de musica. Edited by Christian Meyer and Guy Lobrichon. Corpus Christianorum 250. Turnhout: Brepols, 2012.

Muris, Johannes de. Musica <speculativa.> Edited by Susan Fast. Ottawa: The Institute of Mediaeval Music, 1994.

Page, Christopher. "A Treatise on Musicians from ?c. 1400: The 'Tractatulus de differentiis et gradibus cantorum' by Arnulf De St Ghislain." Journal of the Royal Musical Association 117, no. 1 (1992): 1-21.

Pesic, Peter. Music and the Making of Modern Science. Cambridge, Massachusetts: MIT Press, 2014.

Porres, Beatriz, and José Chabás. "John of Murs's Tabulae Permanentes for Finding True Syzygies." Journal for the History of Astronomy 32, no. 1 (2001): 63-72.

Poulle, Emmanuel. "Jean de Murs et les tables Alphonsines." Archives d'histoire doctrinale et littéraire du Moyen Age 47 (1980): 241-71.

— ed. Les Tables Alphonsines: Avec les Canons de Jean de Saxe. Paris: Éditions du Centre National de la Recherche Scientifique, 1984.

Scott, Robert Todd. "Franco of Cologne's Ars cantus mensurabilis: Complete Critical Edition, with Commentary, Translation, Index Verborum, and Loci Paralleli." PhD. diss., Boston University, 1999. ProQuest (9928214).

Scotus, John Duns, Girard Etzkorn, and Allan B. Wolter. Questions on the Metaphysics of Aristotle. St. Bonaventure, NY: Franciscan Institute Publications, 1997.

Toomer, G. J., trans. Ptolemy's Almagest. New York: Springer-Verlag, 1984. 
Weber, Laura. "Intellectual Currents in Thirteenth Century Paris: A Translation and Commentary on Jerome of Moravia's Tractatus de musica." PhD. diss., Yale University, 2009. ProQuest (3395985).

\section{SECONDARY SOURCES:}

Barbera, André, ed. Music Theory and Its Sources: Antiquity and the Middle Ages. Notre Dame, Indiana: University of Notre Dame Press, 1990.

Bauch, Martin, and Gerrit Jasper Schenk, eds. The Crisis of the 14th Century. Berlin: De Gruyter, 2020.

Beaujouan, Guy. "Motives and Opportunities for Science in Medieval Universities." In Scientific Change: Historical Studies in the Intellectual, Social and Technical Conditions for Scientific Discovery and Technical Invention, from Antiquity to the Present, edited by A. C. Crombie, 219-36. New York: Basic Books Inc., Publishers, 1963.

Bent, Margaret, and Andrew Wathey. "Vitry, Philippe de." Grove Music Online. 2001; Accessed 7 Sep. 2020.

https://www.oxfordmusiconline.com/grovemusic/view/10.1093/gmo/9781561592 630.001.0001/omo-9781561592630-e-0000029535.

Boudet, Jean-Patrice. "Jean des Murs, Astrologer." Erudition and the Republic of Letters 4, no. 1 (2019): 123-45.

Brimblecombe, Peter. "Climate Conditions and Population Development in the Middle Ages." Saeculum 39, no. 2 (1988): 141-48.

Brown, Neville. History and Climate Change: An Eurocentric Perspective. Routledge Studies in Physical Geography and Environment 3. London: Routledge, 2001.

Burnett, Charles. "Sound and its Perception in the Middle Ages." In The Second Sense: Studies in Hearing and Musical Judgement from Antiquity to the Seventeenth Century, edited by Charles Burnett, Michael Fend, and Penelope Gouk, 43-69. London: Warburg Institute, University of London, 1991.

Busse Berger, Anna Marie. "The Evolution of Rhythmic Notation." In The Cambridge History of Western Music Theory, edited by Thomas Christensen, 628-56. Cambridge: Cambridge University Press, 2002.

Carey, Hilary M. Courting Disaster: Astrology at the English Court and University in the Later Middle Ages. New York: St. Martin's Press: 1992. 
Carpenter, Nan Cooke. Music in the Medieval and Renaissance Universities. New York: Da Capo Press, 1972. [Originally published by the University of Oklahoma Press, 1958.]

—. "The Study of Music at the University of Paris in the Middle Ages." Journal of Research in Music Education 2, no. 2 (1954): 119-33.

Chabás, José, and Bernard R. Goldstein. The Alfonsine Tables of Toledo. Dordrecht: Kluwer Academic Publishers, 2003.

—. "Early Alfonsine Astronomy in Paris: The Tables of John Vimond (1320)." Suhayl 4 (2004): 207-94.

—. "Equation of Time." In Time, Astronomy, and Calendars: Survey of European Astronomical Tables in the Late Middle Ages, 37-41. Leiden: Brill, 2012.

—. "John of Murs Revisited: The Kalendarium Solis et Lune for 1321." Journal for the History of Astronomy 43, no. 4 (2012): 411-37.

—. "John of Murs's Tables of 1321." Journal for the History of Astronomy 40, no. 3 (2009): 297-320.

Clagett, Marshall. The Science of Mechanics in the Middle Ages. Madison, University of Madison Press, 1959.

Contamine, Philippe. "The Norman 'Nation' and the French 'Nation' in the Fourteenth and Fifteenth Centuries." In England and Normandy in the Middle Ages, edited by David Bates and Anne Curry, 215-34. London: The Hambledon Press, 1994.

Courtenay, William J. Parisian Scholars in the Early Fourteenth Century: A Social Portrait. Cambridge: Cambridge University Press, 1999.

Crombie, A. C. "Quantification in Medieval Physics." Isis 52, no. 2 (1961): 143-60.

Crosby, Alfred W. The Measure of Reality: Quantification and Western Society, 12501600. Cambridge: Cambridge University Press, 1997.

Crossley, John N., and Carol Williams. "Studying Musica in Thirteenth-Century Paris: The Expectations of Johannes de Grocheio." In Mews and Crossley, Communities of Learning, 137-50.

Desmond, Karen. "Behind the Mirror: Revealing the Context of Jacobus's Speculum musicae." Ph.D diss., New York University, 2009. 
—. "Did Vitry Write an Ars vetus et nova?" The Journal of Musicology 32, no. 4 (2015): 441-93.

—. "Jean des Murs and the Three Libelli on Music in Bnf lat. 7378A: A Preliminary Report." Erudition and the Republic of Letters 4, no. 1 (2019): 40-63.

-. Music and the moderni, 1300-1350: The ars nova in Theory and Practice. Cambridge: Cambridge University Press, 2018.

Diaz, Henry F., Ricardo Trigo, Malcolm K. Hughes, Michael E. Mann, Elena Xoplaki, and David Barriopedro. "Spatial and Temporal Characteristics of Climate in Medieval Times Revisited." Bulletin of the American Meteorological Society 92, no. 11 (2011): 1487-1500.

Diergarten, Felix. "Omnis ars ex experimentis dependeat: 'Experiments' in FourteenthCentury Musical Thought." In Experimental Affinities in Music, edited by Paulo de Assis, 42-63. Leuven: Leuven University Press, 2015.

Dod, Bernard G. "Aristoteles latinus." In Kretzmann, et al., The Cambridge History of Later Medieval Philosophy, 43-79.

Dyer, Joseph. "Music, Passion and Virtue in Two Quodlibetal Questions of the Philosopher Pierre d'Auvergne." Philomusica On-line 15, no. 2 (2016): n. pag.

-. "The Place of Musica in Medieval Classifications of Knowledge." The Journal of Musicology 24, no. 1 (2007): 3-71.

Egbert, Virginia Wylie. On the Bridges of Mediaeval Paris: A Record of Early Fourteenth-Century Life. New Jersey: Princeton University Press, 1974.

Everist, Mark, ed. The Cambridge Companion to Medieval Music. Cambridge: Cambridge University Press, 2011.

-. "The Thirteenth Century." In Everist, The Cambridge Companion to Medieval Music, 67-86.

Farmer, Sharon. Surviving Poverty in Medieval Paris: Gender, Ideology, and the Daily Lives of the Poor. Ithaca, N.Y.: Cornell University Press, 2002.

Feke, Jacqueline. "Ptolemy in Philosophical Context: A Study of the Relationships Between Physics, Mathematics, and Theology." PhD., diss., University of Toronto, 2009. 
Fuller, Sarah. "A Phantom Treatise of the Fourteenth Century? The Ars Nova." The Journal of Musicology 4, no. 1 (1985): 23-50.

Geremek, Bronisław. The Margins of Society in Late Medieval Paris. Past and Present Publications. Cambridge: Cambridge University Press, 1987.

Gieysztor, Aleksander. "Management and Resources." In Before the Black Death: Studies in the 'Crisis' of the Early Fourteenth Century, edited by Bruce M.S. Campbell, 108-43. Manchester: Manchester University Press, 1991.

Grant, Edward. The Foundations of Modern Science in the Middle Ages: Their Religious, Institutional, and Intellectual Contexts. Cambridge: Cambridge University Press, 1996.

—. "Medieval Natural Philosophy: Empiricism without Observation." In The Nature of Natural Philosophy in the Late Middle Ages, 195-224. Washington, D.C.:

Catholic University of America Press, 2010.

-. "Science in the Medieval University." In The Nature of Natural Philosophy in the Late Middle Ages, 16-48. Washington, D.C.: The Catholic University of America Press, 2010.

—, ed. A Source Book in Medieval Science. Cambridge, Mass.: Harvard University Press, 1974.

Grant, Lindy. Architecture and Society in Normandy: 1120 to 1270. New Haven: Yale University Press, 2005.

Gushee, Lawrence. "Jehan des Murs and his Milieu." In Musik—und die Geschichte der Philosophie und Naturwissenschaften im Mittelalter: Fragen zur Wechselwirkung von "Musica" und "Philosophia" im Mittelalter, edited by Frank Hentschel, 33971. Studien und Texte zur Geistesgeschichte des Mittelalters 62. Leiden: Brill, 1998.

—. "New Sources for the Biography of Johannes de Muris." Journal of the American Musicological Society 22, no. 1 (1969): 3-26.

—. "Two Central Places: Paris and the French Court in the Early Fourteenth Century." In Bericht über den Internationalen Musikwissenschaftichen Kongress Berlin 1974, edited by Hellmut Kühn and Peter Nitsche, 135-57. Kassel: Bärenreiter, 1980.

—. "Questions of Genre in Medieval Treatises on Music." In Gattungen der Musik in Einzeldarstellungen: Gedenkschrift Leo Schrade, edited by Wulf Arlt, Ernst Lichtenhahn, and Hans Oesch, 365-433. Bern: Francke, 1975. 
Gushee, Lawrence, and C. Matthew Balensuela (with Jeffrey Dean). "Muris, Johannes de." In The New Grove Dictionary of Music and Musicians. Edited by Stanley Sadie, 17:409-13. 2nd ed. London: Macmillan, 2001. Also available online: http://www.oxfordmusiconline.com.proxy.lib.pdx.edu/grovemusic/view/10.1093/ gmo/9781561592630.001.0001/omo-9781561592630-e-0000014237.

Gushee, Marion S. "The Polyphonic Music of the Medieval Monastery, Cathedral and University." In McKinnon, Antiquity and the Middle Ages, 143-69.

Haines, John, and Patricia DeWitt. "Johannes de Grocheio and Aristotelian Natural Philosophy." Early Music History 27 (2008): 47-98.

Hart, Roger. "The Great Explanandum." American Historical Review 105, no. 2 (April 2000): 486-93.

Harvey, Barbara F. "Introduction: The 'Crisis' of the Early Fourteenth Century." In Before the Black Death: Studies in the 'Crisis' of the Early Fourteenth Century, edited by Bruce M.S. Campbell, 1-24. Manchester: Manchester University Press, 1991.

Harvey, Margaret. "Travel from Durham to York (and Back) in the Fourteenth Century." Northern History 42, no. 1 (2005): 119-30.

Heller-Roazen, Daniel. The Fifth Hammer: Pythagoras and the Disharmony of the World. New York: Zone Books, 2011.

Herlinger, Jan. "Music Theory of the Fourteenth and Early Fifteenth Centuries." In Strohm and Blackburn, Music as Concept and Practice in the Late Middle Ages, 244-300.

Hughes, Don Anselm, and Gerald Abraham, eds. Ars Nova and the Renaissance, 13001540. New Oxford History of Music 3. London: Oxford University Press, 1960.

Huglo, Michel. "The Study of Ancient Sources of Music Theory in the Medieval Universities." In Barbera, Music Theory and Its Sources, 150-72.

Husson, Matthieu. "Exploring the Temporality of Complex Computational Practice: Two Eclipse Notes by John of Murs in the ms Escorial O II 10." Centaurus 58, no. 1-2 (2016): 46-65.

Jacob, Margaret C. "Thinking Unfashionable Thoughts, Asking Unfashionable Questions." The American Historical Review 105, no. 2 (2000): 494-500. 
Jeffreys, Catherine. "The Exchange of Ideas About Music in Paris c. 1270-1304: Guy of Saint-Denis, Johannes de Grocheio, and Peter of Auvergne." In Mews and Crossley, Communities of Learning, 152-75.

Johnstone, Mark A. "Aristotle on Sounds." British Journal for the History of Philosophy 21, no. 4 (2013): 631-48.

Jordan, William C. The Great Famine: Northern Europe in the Early Fourteenth Century. Princeton, N.J.: Princeton University Press, 1996.

Kaye, Joel. Economy and Nature in the Fourteenth Century: Money, Market Exchange, and the Emergence of Scientific Thought. Cambridge: Cambridge University Press, 1998.

Kibre, Pearl. "The Quadrivium in the Thirteenth Century Universities (with Special Reference to Paris)." In Arts libéraux et philosophie au Moyen Age, 175-91. Montréal: Institut d'Études Médiévales, 1969.

-. Scholarly Privileges in the Middle Ages: The Rights, Privileges, and Immunities of Scholars and Universities at Bologna, Padua, Paris, and Oxford. Cambridge: Mediaeval Academy of America, 1962.

Kibre, Pearl, and Nancy Siraisi. "The Institutional Setting: The Universities." In Science in the Middle Ages, edited by David Lindberg, 120-44. Chicago: University of Chicago Press, 1978.

Kretzmann, Norman, Anthony Kenny, Jan Pinborg, and Eleonore Stump, eds. The Cambridge History of Later Medieval Philosophy: From the Rediscovery of Aristotle to the Disintegration of Scholasticism, 1100-1600. Cambridge: Cambridge University Press, 1982.

Leech-Wilkinson, Daniel. "Ars Antiqua-Ars Nova—Ars Subtilior." In McKinnon, Antiquity and the Middle Ages, 218-40.

—. "The Emergence of ars nova." The Journal of Musicology 13, no. 3 (1995): 285-317.

Leff, Gordon. Paris and Oxford Universities in the Thirteenth and Fourteenth Centuries: An Institutional and Intellectual History. New York: John Wiley and Sons, 1968.

—. "The Trivium and the Three Philosophies." In Ridder-Symoens, Universities in the Middle Ages, 307-36. 
Leitmeir, Christian Thomas. "Sine Auctoritate Nulla Disciplina Est Perfecta: Medieval Music Theory in Search of Normative Foundations." In Between Creativity and Norm-Making: Tensions in the Later Middle Ages and the Early Modern Era, edited by Sigrid Müller and Cornelia Schweiger, 31-60. Leiden: Brill, 2013.

Lemay, Richard. "The Teaching of Astronomy in Medieval Universities, Principally at Paris in the Fourteenth Century." In Science, Medicine and the University: 12001550, Essays in Honor of Pearl Kibre, Part II, edited by Nancy G. Siraisi and Luke Demaitre. Special issue, Manuscripta 20, no. 3 (1976): 197-217.

Lindberg, David C. The Beginnings of Western Science: The European Scientific Tradition in Philosophical, Religious, and Institutional Context, 600 B.C. to A.D. 1450. Chicago: University of Chicago Press, 1992.

Lohr, C. H. "The Medieval Interpretation of Aristotle." In Kretzmann, et al., The Cambridge History of Later Medieval Philosophy, 80-98.

Lucas, Henry S. "The Great European Famine of 1315, 1316, and 1317." Speculum 5, no. 4 (1930): 343-77.

McKinnon, James, ed. Antiquity and the Middle Ages: From Ancient Greece to the 15th Century. Englewood Cliffs, N.J.: Prentice Hall, 1990.

Mews, Constant J., and John N. Crossley, eds. Communities of Learning: Networks and the Shaping of Intellectual Identity in Europe, 1100-1500. Turnhout: Brepols, 2011.

Miolo, Laure. "In Quest of Jean des Murs's Library: An Overview of His Readings and Uses of Manuscripts." Erudition and the Republic of Letters 4, no. 1 (2019): 1339.

Moody, Ernest A. "Empiricism and Metaphysics in Medieval Philosophy." The Philosophical Review 67, no. 2 (1958): 145-63.

Murdoch, John E. "The Development of a Critical Temper: New Approaches and Modes of Analysis in Fourteenth-Century Philosophy, Science, and Theology." In Medieval and Renaissance Studies, edited by Siegfried Wenzel, 51-79. Chapel Hill: The University of North Carolina Press, 1978.

-. "From Social into Intellectual Factors: An Aspect of the Unitary Character of Late Medieval Learning." In The Cultural Context of Medieval Learning, edited by John E. Murdoch and Edith D. Sylla, 271-348. Dordrecht: D. Reidel, 1975. 
—. "Mathesis in philosophiam scholasticam introducta: The Rise and Development of the Application of Mathematics in Fourteenth Century Philosophy and Theology." In Arts libéraux et philosophie au moyen age, 215-49. Montréal: Institut d'Études Médiévales, 1969.

Murray, Alexander. Reason and Society in the Middle Ages. Oxford: Clarendon Press, 1978.

Nederman, Cary J. "Aristotle as Authority: Alternative Aristotelian Sources of Late Mediaeval Political Theory." History of European Ideas 8, no. 1 (1987): 31-44.

Neveux, François. "La constitution d'un réseau urbain en Normandie." In Les villes normandes au Moyen Âge, edited by Pierre Bouet and François Neveux, 45-60. Caen: Presses Universitaires de Caen, 2006. http://books.openedition.org/puc/9445.

-. A Brief History of the Normans: The Conquest That Changed the Face of Europe, in collaboration with Claire Ruelle and translated by Howard Curtis. London: Constable and Robinson, 2008.

Nothaft, C. Philipp. "Critical Analysis of The Alfonsine Tables in the Fourteenth Century: The Parisian Expositio Tabularum Alfonsii of 1347." Journal for the History of Astronomy 46, no. 1 (2015): 76-99.

—. "John of Murs and the Treatise Autores Kalendarii (1317): A Problem of Authorship." Sudhoffs Archiv 99, no. 2 (2015): 209-29.

-. "Science at the Papal Palace: Clement VI and the Calendar Reform Project of 1344/1345." Viator 46, no. 2 (2015): 277-302.

Nothaft, C. Philipp E., Karen Desmond, and Mathieu Husson. "Jean des Murs's Quadrivial Pursuits: Introduction." Erudition and the Republic of Letters 4, no. 1 (2019): 1-12.

Novikoff, Alex J. The Medieval Culture of Disputation: Pedagogy, Practice, and Performance. Philadelphia: University of Pennsylvania Press, 2013.

Overman, Steven Joe. "The Student in the Medieval University." Ph.D. diss., Washington State University, 1971.

Page, Christopher. Discarding Images: Reflections on Music and Culture in Medieval France. Oxford: Clarendon Press, 1993. 
—. "The Geography of Medieval Music." In Everist, The Cambridge Companion to Medieval Music, 320-34.

-. The Owl and the Nightingale: Musical Life and Ideas in France 1100-1300. London: J.M. Dent and Sons, 1989.

Pasnau, Robert. "Entia Successiva." In Metaphysical Themes 1274-1671, 374-98. Oxford: Oxford University Press, 2011.

—. "Sensible Qualities: The Case of Sound." Journal of the History of Philosophy 38, no. 1 (2000): 27-40.

Pedersen, Olaf. "Astronomy." In Science in the Middle Ages, edited by David C. Lindberg, 303-37. Chicago: Chicago University Press, 1978.

—. "Some Early European Observatories." Vistas in Astronomy 20 (1976): 17-28.

Pesce, Dolores. "Theory and Notation." In Everist, The Cambridge Companion to Medieval Music, 276-90.

Post, Gaines. "Master's Salaries and Student-Fees in Mediaeval Universities." Speculum 7, no. 2 (1932): 181-98.

Poulle, Emmanuel. "John of Murs." In Dictionary of Scientific Biography, edited by Charles C. Gillispie, 7:128-33. New York: Scribner, 1970.

—. "The Alfonsine Tables of Alfonso X of Castille." Journal for the History of Astronomy 19, no. 2 (1988): 97-113.

Pride, Ellen Perry. "Student Life in the Medieval Universities." The Social Studies 32, no. 6 (1941): 267-71.

Rashdall, Hastings. The Universities of Europe in the Middle Ages, vol. 1, edited by F. M. Powicke and A. B. Emden. Oxford University Press, 1936.

Rico, Gilles. "Music in the Arts Faculty of Paris in the Thirteenth and Early Fourteenth Centuries." D.Phil. Thesis, Christ Church College, 2005. http://www.diamm.ac.uk/redist/pdf/ricoFull.pdf.

Ridder-Symoens, Hilde De, ed. Universities in the Middle Ages. Vol. 1 of A History of the University in Europe. Cambridge: Cambridge University Press, 1992.

—. "Mobility." In Ridder-Symoens, Universities in the Middle Ages, 280-306. 
Salmen, Walter. "Dances and Dance Music, c. 1300-1530." In Strohm and Blackburn, Music as Concept and Practice in the Late Middle Ages, 162-90.

Schwinges, Rainer Christoph. "Admission." In Ridder-Symoens, Universities in the Middle Ages, 171-94.

—. "Student Education, Student Life." In Ridder-Symoens, Universities in the Middle Ages, 195-243.

Skinner, Quentin. "Meaning and Understanding in the History of Ideas." History and Theory 8, no. 1 (1969): 3-53.

Strayer, Joseph R. The Administration of Normandy under Saint Louis. New York: AMS Press, 1971.

—. The Reign of Philip the Fair. Princeton, N.J.: Princeton University Press, 1980.

Strobach, Nico. The Moment of Change: A Systematic History in the Philosophy of Space and Time. Dordrecht: Kluwer Academic Publishers, 1998.

Strohm, Reinhard, and Bonnie J. Blackburn, eds. Music as Concept and Practice in the Late Middle Ages. Vol. 3.1 of The New Oxford History of Music. Oxford: Oxford University Press, 2001.

Tanay, Dorit. "The Image of Music and the Bodies of Knowledge in the Late Middle Ages: Rhythmic Procedures as Cultural Representations." Science in Context 9, no. 2 (1996): 121-36.

—. "Jehan de Meur's Musical Theory and the Mathematics of the Fourteenth Century." Tractrix 5 (1993): 17-43.

-. "Music in the Age of Ockham: The Interrelations Between Music, Mathematics, and Philosophy in the Fourteenth Century." Ph.D. diss., University of California, Berkeley, 1989.

- Noting Music, Marking Culture: The Intellectual Context of Rhythmic Notation, 1250-1400. Musicological Studies and Documents 46. Holzgerlingen: American Institute of Musicology, 1999.

—. "'Nos faysoms contre Nature ... ': Fourteenth-Century Sophismata and the Musical Avant Garde." Journal of the History of Ideas 59, no. 1 (1998): 29-51.

—. "Time and Money: A New Look at the Mathematical Foundation of the Ars Nova." Dutch Journal of Music Theory 15 (2010): 18-31. 
-. "The Transition from the Ars Antiqua to the Ars Nova: Evolution or Revolution?" Musica Disciplina 46 (1992): 79-104.

Taruskin, Richard. Music from the Earliest Notations to the Sixteenth Century. Vol. 1 of The Oxford History of Western Music. Oxford: Oxford University Press, 2010.

Thorndike, Lynn. A History of Magic and Experimental Science, Volumes III and IV: Fourteenth and Fifteenth Centuries. New York: Columbia University Press, 1934.

-. Introduction to The Sphere of Sacrobosco and its Commentators, 1-75. Translated and edited by Lynn Thorndike. Chicago: University of Chicago Press, 1949.

Thorndike, Lynn, and George Sarton. "Notes and Correspondence." Isis 14, no. 2 (1930): $420-24$.

Weisheipl, James A. "The Interpretation of Aristotle's Physics and the Science of Motion." In Kretzmann, et al., The Cambridge History of Later Medieval Philosophy, 519-36.

-. "The Place of the Liberal Arts in the University Curriculum During the XIVth and XVth Centuries." In Arts libéraux et philosophie au moyen age, 209-13. Montréal: Institut d'Études Médiévales, 1969.

Weller, Philip. "Frames and Images: Locating Music in Cultural Histories of the Middle Ages." Journal of the American Musicological Society 50, no. 1 (1997): 7-54.

Whitney, Elspeth. Paradise Restored: The Mechanical Arts from Antiquity through the Thirteenth Century. Transactions of the American Philosophical Society 80, pt. 1. Philadelphia: The American Philosophical Society, 1990.

Wright, Craig M. Music and Ceremony at Notre Dame of Paris, 500-1550. Cambridge Studies in Music. Cambridge: Cambridge University Press, 1989.

Yudkin, Jeremy. "The Influence of Aristotle on French University Music Texts." In Barbera, Music Theory and Its Sources, 173-89. 
Appendix

Translation of Book I of the Notitia artis musicae

\section{"Prologue"}

The prince of philosophers, Aristotle, says in the introduction to his Metaphysics: Without qualification, the sign of a knowledgeable man is the ability to teach. ${ }^{1}$ However, in any art, theorists can teach, [but] practitioners cannot. For men of experience (experti), know the thing itself, but they do not know the wherefore. ${ }^{2}$ They do not, moreover, do what they do out of knowledge (scientia), but rather in the way that fire burns. ${ }^{3}$ But we judge that understanding and knowing about every single art is more by art than experience (experimento). For that reason, we suppose that masters of an art are wiser than men of experience (expertis). ${ }^{4}$ And on account of this, we consider art, more than [practical] experience (experimento), to be knowledge (scientiam). For the former can teach, but the latter cannot. ${ }^{5}$ Nevertheless, insofar as art is of the universal, and experience (experimentum), on the other hand, of the singular, the universal presupposes the singular, ${ }^{6}$ therefore art presupposes experience. Experience indeed has brought about art, and we see men of experience make more headway than those who have "reason without experience." ${ }^{17}$ Therefore, it is necessary in every single art to have first a theory, [and then] a corresponding practice, so that the thing which was known in the universal can be applied to the singular. But, since every art is derived from experience (experimentis), it is proper for every single master of an art first to take pains regarding the experiential (experimentam) side of art. We, however, for the sake of the general good and for reasons of showing the truth, which long lay hidden, propose to be vigilant about revealing the art of music, setting about to elucidate ${ }^{8}$ two things about it in a concise manner: first the theoretical, second the practical - to which it is not unsuitable that some theory be connected.

\section{Book I: Theoretical Music}

Seeing that music is sound related to numbers, or vice versa, it is clearly necessary for musicians ${ }^{9}$ to consider both number and sound. Now, before anything is numbered, it is necessary for it to exist. Therefore, it is necessary for sound to be

\footnotetext{
${ }^{1}$ Aristotle, Metaphysics, A.1, $981^{\mathrm{b}} 7$.

2 Ibid., 981 29-31.

${ }^{3}$ Ibid., $981^{\mathrm{b}} 4$.

${ }^{4}$ Ibid., 981 a 24-26 (includes previous sentence).

${ }^{5}$ Ibid., $981^{\mathrm{b}} 8-9$ (includes previous sentence).

${ }^{6}$ Ibid., $981^{\text {a }} 15-16$.

7 Ibid., $981^{\text {a }} 14-15$.

${ }^{8}$ The word here is enodare, which literally means 'to unknot,' but 'to make plain, to explain, and elucidate' give the general sense.

${ }^{9}$ That is, those interested in knowledge of the art of music.
} 
produced before being counted. For the generation of sound, three things are required: a striker, a struck thing, and a medium fit to be struck. First, something breaking the air swiftly; second, a naturally sonorous body; third, air broken violently. A stroke is not made without motion, and so neither does sound exist without motion. Sound is therefore the breaking of air from the impact of the thing striking on the thing struck. For it is impossible for a sound to be made when there is only one thing. Of sounds, one is low, another is high. The low is that which is produced from slower and more diffuse motion, the high, that which is joined together from more rapid and dense motion. Although in both [low and high sounds] there are many discrete motions making sounds many in number, as is revealed in the struck gut-strings, nevertheless they are heard without perceptible interruption as one uninterrupted sound because of the speed of the joined motions, just as the color of the uppermost surface of a top set in motion is seen to be a circular line, although it was nothing other than a point. ${ }^{10} \mathrm{~A}$ high sound, then, is made out of a low one through the addition of motion; likewise, a low one is made out of a high one through subtraction. Thus, in high sounds there are more motions; in low, fewer. Moreover, every paucity is related to a plurality expressed numerically. Therefore, it is necessary for a low sound to be expressed in relation to a high sound by comparing them, just as the number of the motions of one is comparable proportionally to the number of the motions of the other.

Since music is shown to be composed of sounds, which are proportional to one another in a certain way according to the numbers of motions found in them, it is not useless to give a general description of numerical proportions. Moreover, every number in comparison to another is either equal or unequal to it, for these [concepts] apply to any given quantity. If equal, they are the same and one in quantity. Therefore, they do not vary, nor is a consonance made out of equal sounds. If unequal, [it is] either greater or lesser [than the other]. Moreover, the one is called greater than the other in five ways: multiplex, superparticular, superpartient, multiplex superparticular, multiplex superpartient. And as you would expect, by adding the prefix "sub," one is called less than the other in all these ways. ${ }^{11}$ It is multiplex when the greater number has in itself two or three or four times the whole smaller number, and its species are double, triple ratio and so on into infinity. ${ }^{12}$ The superparticular is when the greater number contains the smaller and any [one] part of it, and its types are sesquialtera, sesquitertia, and so on successively. ${ }^{13}$ The superpartient is when the greater number contains the smaller and any parts of it, and its types are superbipartiens, supertripartiens, and so on forever. ${ }^{14} \mathrm{~A}$ multiplex superparticular is when the greater number has twice or three times the smaller and any part of it, and its types are duplexsesquialtera, duplexsesquitertia, triplexsesquialtera, and thus for both elements into infinity. ${ }^{15}$ A multiple superpartient is

\footnotetext{
${ }^{10}$ Boethius, De insitutione musica, I.3.

${ }^{11}$ Boethius, De institutione arithmetica, II.22. E.g., submultiplex, subsuperparticular, etc.

${ }^{12}$ E.g., $2: 1$ and $3: 1$.

${ }^{13}$ E.g., $3: 2$ and $4: 3$.

${ }^{14}$ E.g., $5: 3$ and $7: 4$.

${ }^{15}$ E.g., $5: 2,7: 3$, and $7: 2$.
} 
when the greater number has twice or three times the smaller and any parts of it, and its types are duplexsuperbipartiens, duplexsupertripartiens, and thus by adding whatever type of multiplex to whatever [type] of superpartient. ${ }^{16}$ Examples of each type can be expressed numerically as follows:

\begin{tabular}{|l|l|r|r|r|r|}
\hline \multirow{2}{*}{ 1. multiplex } & tripla & 36 & 72 & 108 & 144 \\
\cline { 2 - 5 } & dupla & 24 & 48 & 72 & 96 \\
\hline \multirow{2}{*}{ 2. superparticularis } & sesquitertia & 16 & 32 & 48 & 64 \\
\cline { 2 - 6 } & sesquialtera & 18 & 36 & 54 & 72 \\
\hline \multirow{2}{*}{ 3. superpartiens } & supertripartiens & 21 & 42 & 63 & 84 \\
\cline { 2 - 6 } & superbipartiens & 20 & 40 & 60 & 80 \\
\hline \multirow{2}{*}{ 4. muliplex superparticularis } & duplasesquialtera & 40 & 60 & 90 & 120 \\
\cline { 2 - 6 } & triplasesquitertia & 32 & 64 & 120 & 160 \\
\hline \multirow{2}{*}{ 5. multiplex superpartiens } & duplasuperbipartiens & 45 & 90 & 135 & 128 \\
\cline { 2 - 6 } & triplasupertripartiens & 12 & 24 & 36 & 48 \\
\hline \multicolumn{2}{|l|}{ base of relationship } & & 30 & 180 \\
\hline
\end{tabular}

Pythagoras, unwilling to adhere to the judgment of the ears concerning consonances, because it is not unusual that any given sense be deceived regarding that which is not its own - for the ear appraises sound, [but] it does not grasp proportionremaining anxious for a long time about how he might discover, in accordance with reason, knowledge about consonance, by chance passing the workshops of craftsmen, heard hammers emitting a certain wondrous consonance. And at once, as if struck by lightning, he was drawn toward them and, doubting whether the melody could have come forth from the exertions of the men, ordered that the hammers be rearranged randomly, and perceiving the same thing as before, he observed that the harmony was contained in the given nature of the hammers. The number of the hammers was five, but the fifth was thrown out, since it was dissonant. Thus, four remained, the weights of which were found in hands-on experimentation [lit., sensible experience] to be in dupla, sesquialtera, sesquitertia, and sesquioctava ratio. He tried out these proportions using strings, hollow bodies, winds, and waters, finding in no case an instance [of variation]. From these experiments, as they converged in his memory, he grasped one universal, which was for him the principle of art and knowledge (scientiae). So that what has been said might be clearer, let the proportion of the hammers be expressed numerically. Therefore, let the weights of the hammers be $12,9,8,6$. Therefore, 6 paired with 12 , with its double ratio, represent a diapason; ${ }^{17}$ furthermore, 12 paired with 9 and 8 paired with 6 , with a sesquitertia ratio, manifest a diatesseron; ${ }^{18} 12$ paired with 8 and 9 paired with 6 , with a sesquialtera ratio, resound a diapente ${ }^{19} 8$ paired with 9 , with a sesquioctava ratio, form a tone. Therefore, only these kinds of multiplex [ratios] belongs among the consonances. Simple consonances must be arranged in simple ratios, composite consonances must be

${ }^{16}$ E.g., $8: 3$ and $11: 4$.

${ }^{17}$ I.e., an octave.

18 I.e., a fourth.

${ }^{19}$ I.e., a fifth. 
arranged in composite proportions. Therefore, a diapason-plus-diapente ${ }^{20}$ is made in a triple ratio, which comes forth out of a double ratio and sesquialtera, thus $2: 4: 6$. A bisdiapason $^{21}$ is made in a quadruple ratio, which is born out of a double ratio, thus $2: 4$ : 8. A diatesseron and diapente render a diapason; indeed, out of a sesquialtera and sesquitertia a double ratio comes forth, thus $2: 3: 4$. A diapente is made out of a sesquitertia and sesquioctava, thus $6: 8: 9$. A diatesseron is composed out of two tones with a semitone, a diapente out of three tones with a semitone. And attaching these two makes a diapason: therefore, a diapason is composed out of five tones with two semitones. But two semitones do not come together in a perfect tone, as will be demonstrated in the following. All of these are revealed in the figure written below.

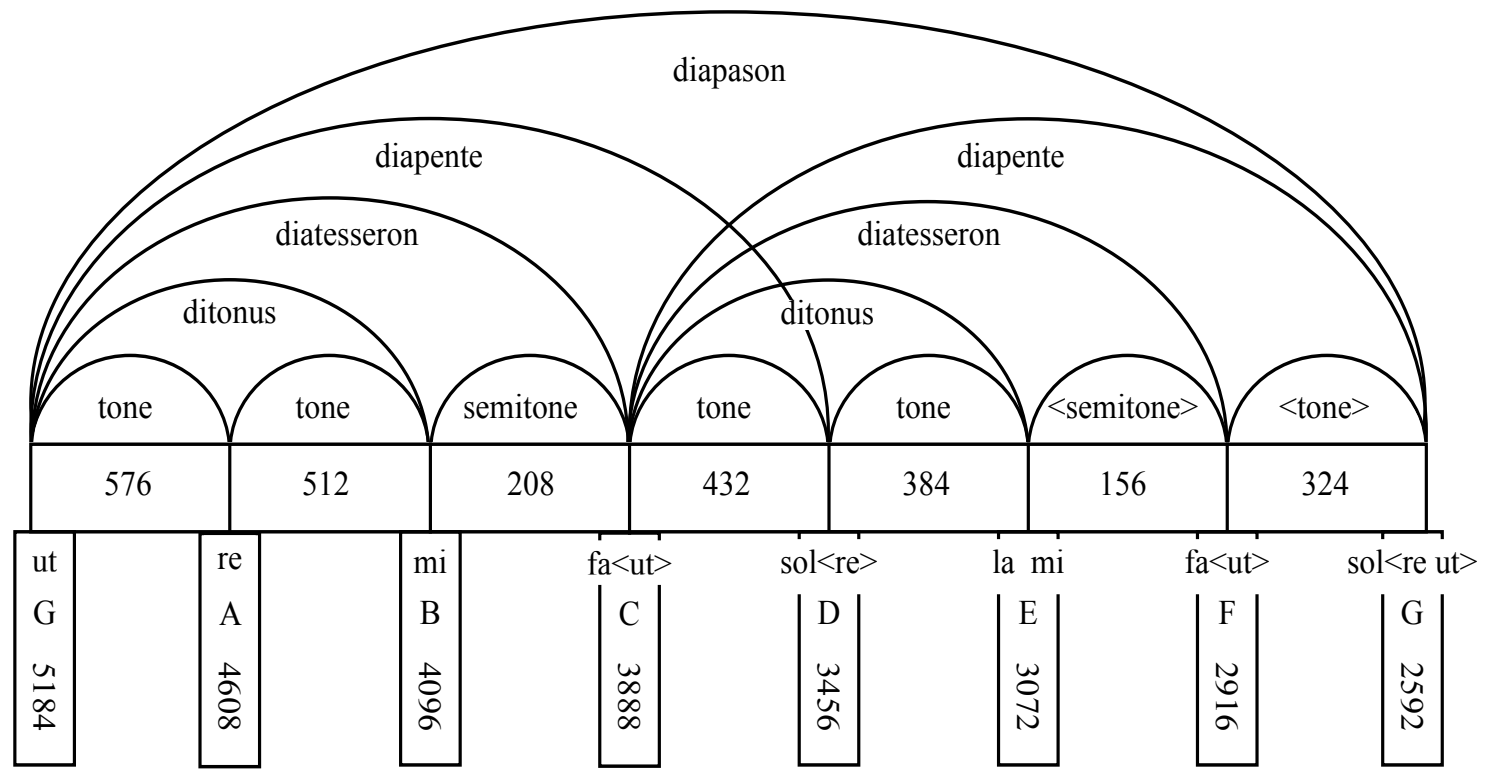

Because the diapason is said to consist of five tones and two semitones, which do not come all the way up to the perfection of six tones, it remains to be shown that the semitone according to pitch may not be the true middle of a tone, as certain scholars in antiquity reckoned. Any kind of half doubled ought to return its total. But the double of the semitone does not wholly return a tone, which is evident when the numbers are in order: 243 and 256 return a semitonal ratio. For 256 compared to 192 in a sesquitertia ratio make up a diatesseron, from which, when you subtract two tones, a semitone remains. Therefore, the difference between 243 and 256 is 13 , twice of which is 26 , which added to 243 is 269 . If this is truly a semitone, then it ought to return a number that produced a tone with a sesquioctava ratio. But it doesn't, because if an eighth part is added to 243, it will leave a number that produces a tone with sesquioctava ratio, which is 273 and three eighths, which is greater than the preceding number [269]. Therefore, it is not truly a semitone. Furthermore, by a rule of arithmetic, if two numbers be in a certain ratio, [the numbers] produced from those numbers will remain in the same ratio,

${ }^{20}$ I.e., an octave and a fifth or twelfth.

${ }^{21}$ I.e., a double octave. 
e.g., $2: 3$ are in a sesquialtera ratio, and the [numbers] produced from these are $4: 6: 9$, between which is the same sesquialtera ratio. Therefore, 243 multiplied by itself produces 59,049, and 256 multiplied by itself generates 65,536 . That which results out of the multiplication of one root by another is the proportional mean, namely "62,208." Therefore, just as there is a semitonal ratio between the roots, thus [there is the same ratio] between the products. And since there are two [semitonal ratios], therefore, if each is truly half of a tone, there should be a whole tone from the greatest [number] to the least, but nevertheless there is not. In fact, if in addition to the first [number] an eighth part is added, then [this number] will be higher than the third. ${ }^{22}$ Therefore, between the first and second [numbers] there was not a true half tone nor [was there one] between the second and third. For that reason, they could not make up a tone. Therefore, similarly between the roots, which are 243 and 256, there is not an exact half that is a semitone but rather one that is less: this is the declared proposition. And let these [remarks] about the theory of music be sufficient for the listener for the time being.

Nevertheless, subsequent innovators of music developed the understanding of it in various ways: some using instruments of strings; others, instruments of perforated reeds; and others, instruments of wind. Indeed, [certain of these later innovators] developed the understanding of it using pitches represented by the joints of the hand, through letters of the alphabet, with distinct degrees, and with changes made from one degree into another, just as the following chart shows. [See next page]

Michels, Hans Ulrich, ed. Johannes de Muris Notitia artis musicae, et Compendium musicae practicae. Petrus de Sancto Dionysio Tractutus de musica, 47-84. Corpus Scriptorum de Musica 17. American Institute of Musicology, 1972.

\footnotetext{
${ }^{22}$ The ratio for a tone is $8: 9$, or 1 to 1 and $1 / 8.59,049 \div 8=7381.125+59,049=66,430.125$, which is greater than 65,536 .
} 


\begin{tabular}{|c|c|c|c|c|c|c|c|}
\hline & 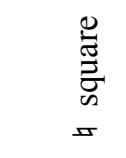 & 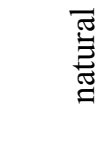 & $\begin{array}{l}\underset{0}{0} \\
0 \\
0\end{array}$ & 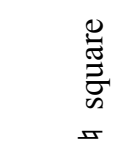 & 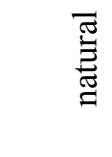 & $\begin{array}{l}\mathbb{D} \\
\infty \\
0 \\
0\end{array}$ & 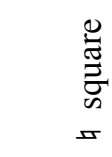 \\
\hline $\begin{array}{l}\mathrm{d} \\
\mathrm{d}\end{array}$ & & & & & & la & sol \\
\hline $\begin{array}{l}\mathrm{c} \\
\mathrm{c}\end{array}$ & & & & & & sol & $\mathrm{fa}$ \\
\hline $\begin{array}{l}b দ \\
b দ\end{array}$ & & & & & & $\mathrm{fa}$ & $\mathrm{mi}$ \\
\hline $\begin{array}{l}\mathrm{a} \\
\mathrm{a}\end{array}$ & & & & & la & $\mathrm{mi}$ & re \\
\hline $\mathrm{g}$ & & & & & sol & $\mathrm{re}$ & ut \\
\hline f & & & & & $\mathrm{fa}$ & ut & \\
\hline e & & & & la & $\mathrm{mi}$ & & \\
\hline $\mathrm{d}$ & & & la & sol & re & & \\
\hline$c$ & & & sol & $\mathrm{fa}$ & ut & & \\
\hline bদ & & & $\mathrm{fa}$ & $\mathrm{mi}$ & & & \\
\hline $\mathrm{a}$ & & la & $\mathrm{mi}$ & re & & & \\
\hline G & & sol & re & ut & & & \\
\hline $\mathrm{F}$ & & $\mathrm{fa}$ & ut & & & & \\
\hline E & la & $\mathrm{mi}$ & & & & & \\
\hline D & sol & re & & & & & \\
\hline $\mathrm{C}$ & $\mathrm{fa}$ & ut & & & & & \\
\hline B & $\mathrm{mi}$ & & & & & & \\
\hline A & re & & & & & & \\
\hline$\Gamma$ & ut & & & & & & \\
\hline & 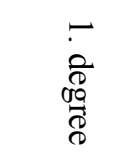 & 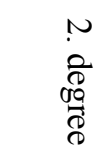 & 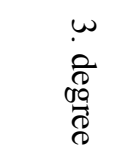 & 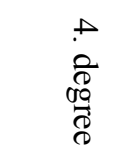 & 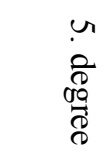 & 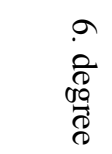 & 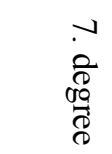 \\
\hline
\end{tabular}

